\title{
CONTRIBUICCÃO AO CONHECIMENTO DE CARACTERISTICAS TECNOLOGICAS DE MATERIAIS ROCHOSOS
}

Riuiti Yoshida

\section{VOLUME I - TEXTO E APENDICES}

Tese de Doutoramento apresentada ao Instituto de Geociências da Universidade de $\mathrm{S}$ ão $\mathrm{P}$ aưlo.

SÃO PAULO

1972 


\title{
CONTRIBUIÇÄO AO CONHECIMENTO DE CARACTERISTICAS TECNOLOGICAS DE MATERIAIS ROCHOSOS
}

Riuiti Yoshida

\begin{abstract}
Tese de doutoramento apresentada ao Instituto de Geociencias da Universidade de Șão Paulo.
\end{abstract}

\section{SÃO PAULO}

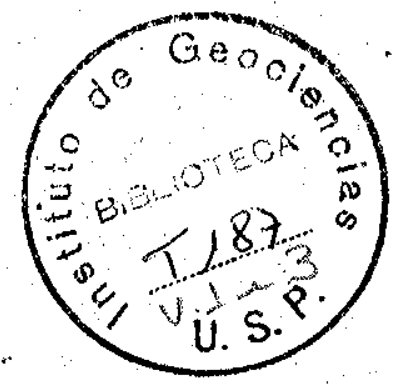

1972

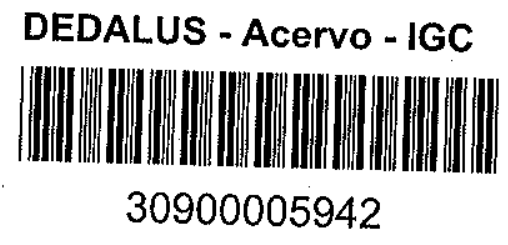




\section{INDICE}

PÁGINA

VOLUME I - TEXTO E APENDICES

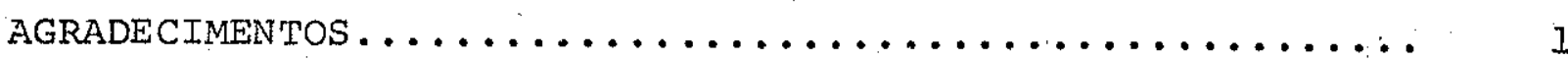

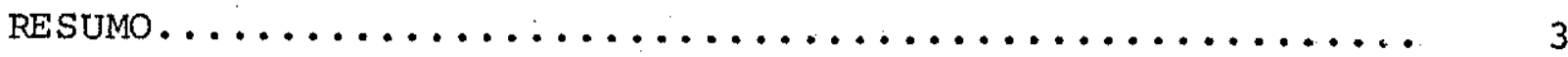

I. - INTRODUÇÃO ........................

II. - GENERAIIDADES SOBRE AS PRORRIEDADES TECNOLÖGICAS... .

III. - METODOLOGIA EMPREGADA................... 21

III.l - Amostragem e mëtodos................. 2j.

III.2 - Procedimentos e tipcs de amostras......... 23

III.3 - Aparelhagem.................... 26

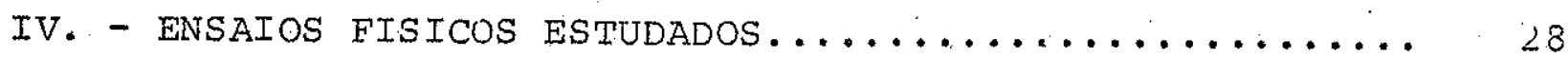

IV. I - Avaliação da resistência de rochas pelo empre go do esclexometro schmidt............. 28

IV.2 - Resistencia ao jmpacto em conpos de prova regulares........................ 35

IV.3 - Resistência ao desgaste a umids de rochas.... 40

V. - ENSAIOS DE ALTHE

V.I - Quadro experimental.................. 44

V.2 - Procediméntos para comparação entre diferentes processos de altexação.................. 45

A) Ensaios de aiteração por lixiviação contínua 46

B) Ensaios de alteração por saturação em ägua

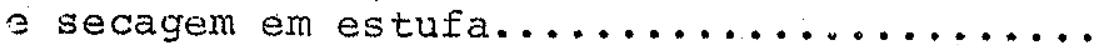

C) Ensaios de alteração por imersăo em etileno glicol e secagen em estufa..............

D) Ensaios de al weraça por imersäo em şolução saturada de sulfado de sódıo e secagem em estufa......................... 


\section{PĂGINA}

M-7 ENSAIO DE RESISTÊNCIA A ALTERAÇÃO EM SOLUÇÃO SATURADA. DE SULFATO DE SODIO E MEDINA DO COMPORTAMENTO MECANI-

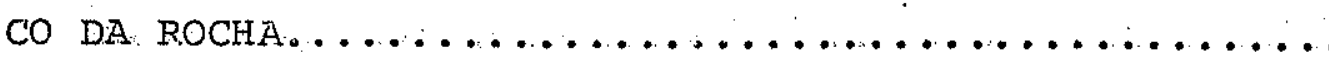

M-8 ENSAIO DE RESISTENCIA A ALTERAÇÃO EN EXPOSIÇÃO NATU RAL E MEDIDA DO COMPORTAMENTO MECANICO DA. ROCHA......

ANEXOS I E II - ESQUEMAS DO APARELHO DE DESGASTE A UMIDO E EXIRATOR SOXHLET.

APENDICE C - PROCEDIMENTO ESTATISTICO PAKA DIMENSIONAMENTO DE AMOSTRAS, APIICABIEIDADE DO METODO DE ENSAIO E CORRELAÇÕES ............... 
Não teria sido possível o desenvolvimento da pesquisa e as conclusões expostas nesta monografia, sem a ajuda e a diretriz seguida por todos os membros da Diretoria da DIVISÃO DE MI NAS E GEOLOGIA APLICADA DO INSTITUTO DE PESQUISAS TECNOLŐGICAS; que nos seja permitido então, expressar inicialmente a nossa mais viva gratidão à pessoa de seu Diretor, o gēologo Dr. Luiz Francisco Rielil Saragictto.

Somos profundamente gratos ao Professor Doutor Viktor Leinz, que nos concedeu a honra de ser o orientador desta tese, sempre nos incentivando no caminho da pesquisa aplicada e de ter acompanhado passo a passo o desenvolvimento de nosso traba lho, que muito deve à sua experiência e bom senso.

Agradecemos aos geólogos Dr. Fernando pires de Camargo e Dr.Guido Guidicini, pelo estímulo concedido, apreciação crítica dos objetivos da tese e confiança nos resultados.

Em especial, somos gratos às CENTRAIS ELETRICAS DE SÃo PAULO, que nos concedeu a permissão de publicar resultados de pesquisas efetuadás pelo convênio CESP-IPT.

Em particular, queremos expressar o nosso sincero reconhecimento ao Prof.Dr.José Eduardo Siqueira Farjallat, que durante - desenvolvimento deste trabalho, foi de uma disponibilidade e auxilio em todos os instantes, e cujas criticas e discussões fo ram de inestimävel valia.

Dentre as inumeras sugestões e criticas, que influencia ram esta pesquisa, estamos profurdamente gratos aos Engenheiros, Dr.Carlos Manoel Nieble e Dr.Fernando Fujimura, que nos auxiliaram a enccitrar um tratamento analítico adequado aos resultados. Agradecamos tambëm, pela colaboração eficiente e prestativa, nossos colegas, os geölogos Carlos Takashi Tatamiya, Luiz Geraldo Caruso, Ana Maria Pocciotei Giroldo e Ely Borges Frazão.

Uma tese exige uma grande quantidade de dados, obtidos a partir de ensaios, onde intervieram os nossos tēcnicos de laboratörio Ivan Reis Librandi, Jose Carlos Delchiaro, Joaquir Ireno, José Antonio dos Santos e Lujis Martins, e os assisterites alunos 
Nelson Baltrusis, Diogo Correa Filho, Dirceu Pagotto Stein. Waldir Renato Paradella, aos quais somos gratos.

Não esqueceremos enfim, de agradecer pela sua colaboração preciosa, na confecção de gräficos e tibelas e no extenso trabatho datilográfico, respectivamente as Srtạ. Mirna Mangini. . e Claudete Maria Russo. 
Neste trabalio foi desenvolvida uma investigação experimental com o objetivo de ampliar o conhecimento sobre caracteriza ção tecnolögica de materiais rochosos de construção, com ênfase no aspecto da alterabilidade. Foram estudadas rochas de 15 localidades representando os seguintes 11 tipos litológicos: basalto compacto, basalto vesicular, basalto microvesicular, diabásio, quartzito, calcário, granıto, charrockito,piroxenito, migmatito e arenito. Os ensaios de laboratörio foram conduzidos em corpos de prova cilíndricos, cúbicos e britados obtidos a partir das amostras enviadas, para determinação dos seguintes indices: mas sa especifica aparente, porosidade aparente, absorção, abrasão Ios Angeles, resistência ao impacto $\mathrm{em}$ corpos de prova regulares, resistência ao impacto Treton, resistência ao esmagamento, resis tência à compressão simples axial, Indice escleromëtrico, resistência ao desgaste a ümido e durabilidade. Foram executados quase 3000 ensaios para obtenção de índices fisicomecânicoș e de durabilidade, por um periodo de aproximadamente 2 anos.

Todos os ensaios foram efetuados en amostras inicialmente lavadas, secas $\in \mathrm{m}$ estufa a $100-110^{\circ} \mathrm{C}$ por aproximadamente 10 ho ras e posteriormente, esfriadas ã temperatura ambiente durante pelo menos 2-3-horas, antes de cada ensaio. Os seguintes ensaios novos for am introduzidos: Indice escleyomëtrico, impacto em corpos ce prova moldados e desgaste a ümido, com discussões a res peito de sua aplicabilidade.

Os resultados de cada grupo de corpos de prova em diferen tes rochas, para estes ensaios novos, forarn submetidos à anälise estatística para obtenção de valores mëdios e coeficientes de van riação para determinar a precisão e o número de ensaios necessários para cada uma destias propriedades. Os resultados mëdios fo ram submetidos à correlação estatística e anälises de regressão pelo método dos mínimos quadrados, para os quais foram determina dos os coeficientes de correlação simples, erros padrão de estimativa e relações funcionais para cada par selecionado de variä 
- veis. Estas relações foram apresentadas gräficamente para comparação visual com os correspondentes resultados de ensaios. A par tir dos resultados obtidos quanto à precisão e reprodutibilidade dos ensaios e verificada sua aplicabilidade, foram elaboradas propostas para métodos de ensaios.

Os ensaios de durabilidade, que constituem a segunda parte deste trabalho, foram executados nas rochas acima mencionadas, cul jas amostras foram submetidas a ciclos sucessivos de, saturação em solução de sulfato de sódio e secagem em estufa,saturação em etilenoglicol e secagem em estufa, saturação em ãgua e secagem em estufa, lixiviação continua no extrator soxhlet e exposição natural, em 2 sëries de ensaios. A primeira sërie consistiu na comparação de processos de alteração e a segunda série, na inves titigação do comportamento mecânico dos materiais rochosos face a diferentes condições fisiccquínicas de alteração artificial e natural. O parâmetro mecânico utilizado neste caso, foi a resistência ao impacto Treton.

Os resultados obtidos na primeira sērie, foram submetidos à anälise de regressão, obtendo-se gráficos de comparação de li nhas teoricas de velocidades de alteração pelos diferentes pro cessos e, gráficos mostrando a influência do fator de escála no processo de alteração.

os resultados da segunda sërie de ensaios, permitiram estabelecer 2 parâmetros numéricos: queda percentual de resistência mecânica e coefjciente de alterabilidade especifica, que refle tem a suscetibilidade das rochas a estes diferentes processos de alteração. A correlação estatística, entre es ses paràmetros numë ricos da alteração e a relação entré as tensões mãximas de ruptu ra, no estado saturado e no estado seco, do ensaio de compressão simples axial, indicou ser esta relação, um indice promissor da alterabilidade de rochas.

Finalmente, discutida a validade destes indices, tendo em vista os resultados encontrados e a ausencia na literatura de pro cedimentos adequados, que permitam classificar as rochas quanto ao comportamento meçănico face à alteraçăo natural ou artificial, foram elaboradas propostas de métodos de ensaios, que poderão preencher esta lacuna. 


\section{I. - INTRODUCÃO}

Os materiais rochosos em construção civil são destinados a servir de suporte de grandes estruturas, aumentar a resistência mecânica de concretos e pavimentos, servir de proteção a ater ros de terra compactada, resistir às mais variadas condições de utilização e enfim, servir como fator econômico importante na redução de custos. Para desempenhar tais funções as rochas de vem antes de tudo possuir boa qualidade física.

Por outro lado, os materiais rochosos ocorrentes na superficie da crosta terrestre estão sujeitos a agentes naturais cu efeitos produzidos por atividades humanas, capares de introdu zir modificações mineralógicas e físicas envolvendo desagrega ção dos constituintes minerais e modificação da resistência rie cânica. Fortanto, as rochas para serem aprovadas como materiais de construção, devem apresentar além da qualidade física, una certa durabilidade.

A qualidade e durabilidade de rochas são definidas por um conjunto de propriedades fisicomecânicas e ợímicas, que podem ser designadas genericamente de propriedades tecrolögicas. Estas propriedades caracterizam por intermédio de indices numëricos,o comportamento de rochas face a diferentes solicitações de er saios. A execução de ensaios de caracterização tecnológica de rochas para sua aprovação como marerial de construção é controlada através das exigências enumeradas pelas diversas especificações de projeto existentes.

Entretanto, a determinação de proprieaađes tecrolögicas en rochas envolve ainda uma série de probleirias. Citsamos abaixc al guns dos principais problemas:

1. Ausência dé uma sistematização adequała para estudc de propriedades tecnológicas para as diversas finalidades.

2. Pouco conhecimento da dependêncía entre as proprieảades tecnológicas e as características petrográficás.

3. Falta de uma representação matemática de propriedades fisticas de rochas.

4. Ausência de um estudo detalhado de processos físicos originados pela ação de diversos campos físicos naturais ou artificiais. 
5. Não concordância de resultados devido a variabilidade de padronizações adotadas.

6. Pequeno nümero de ensaios de caracterização adequados.

7. Falta de conhecimento quanto à validade e aplicabilidade de mêtodos de alteração de rochas em laboratório.

8. Duração demasiadamente elevada na execução de alguns en saios.

Os objetivos principais deste trabalho resumem-se no seguin te:

1. Focalizar algumas propriedades tecnolögicas de materiais rochosos, obtidas às custas de novos ensaics desenvolvidos ou adaptados .

2. Estudar, comparar e desenvolver mëtodos ou procedimen tos para previsão ou avaliação da durabilidade de rochas. 


\section{II. - GENERALIDADES SOBRE AS PROPRIEDADES TECNOLOGICAS}

A prática atual na determinação da qualidade de agregados, em bora tenha alcançado um estágio satisfatörio de desenvolvimento,em virtude da multiplicação de obras de grande porte, ainda deixa a desejar.

A utilização dos diferentes tipos de rochas, para as inüme ras finalidades da construção civil envolve possiveis problemas das mais variadas naturezas tais como: bajxas características mecânicas, alta velocidade de alteração e consequente queda de resis tênçia mecãnica e produção de finos, reatividade com os älcalis do cimento, conteúdo elevado de matéria orgânica e de fragmentos friāveis, má adesividade a ligantes betuminosos, baixa aderência às argamassas, indices inadequados de forma apōs britagem, etc. Portanto, o emprego de agregados sem um conhecimento detalhado de seu comportamento tecnológj.co, poderä levar à construção de estru turas com más características funcionais, de durabilidade duvidosa ou requerer a utilização de elevados coeficientes de segurança e, por conseguinte, onerar os custos.

A execução de ensaios de caracterização tecnolögica de rochas, para sua aprovação como material de construção, é controlada atra vés das exigências enumeradas pelas diversas especificações existentes e que são adotadas frequentemente, sem uma avaliação crite riosa das reais condições de uso (53).

Um dos principais problemas existentes consiste no fato de que, frequentemente, ê requerido um grande intervalo de temo pe Ios ensaios, tornando praticamente impossivel fornecer aos cons trutores e projetistas todas as informações referentes a todos os imateriais tão rapidamente quanto se deseja. Consequentemente, es tes são forçados a émpregar tais dados de acordo com as disponibi lidades e depender de comportamentos conhecidos através de materiais similares e presumivelmente de caracteristicas tecnológicas próximas: Quando a finalidade è o emprego do agregado rochoso para concreto, as determinaçöes de Indices numëricos de qualidade sâo geralmente efetuadas para a resistência mecânica e sanidade. Quando a finalidade é o emprego de materiais rochosos em misturas betuminosas, são efetuadas determinações de aderência preferen cial do agregado ao betume ou ägua, além da resistência mecânica. 
arale lamente aos ensaios de qualidade, são efetuadas determina ções da massa especifica e absorção para fornecer dados para o di mensionamento de misturas ou em estimativas de quantidades requeridas para uso.

Justificando a prática rotineira em relação às determinações de qualidade de materiais rochosos, devemos lembrar que represen tam o desenvolvimento de técricas de ensaio por mais de 50 anos. Durante este perído, muitos métoäos de ensaios foram tentados. Al guns foram apiovados e atê hoje continuam sendo usados enquanto que outros foram abardonados, ou porque a significância das carac teristicas ceterminadas se tomaram inadeguadas pelas modificações no tipo ou uso pela construção, ou porque foram desenvolvidas tĕc nicas mais revresentativas. Entretanto todos estes métodos pos: suem uma caracterifstica geral que é o de tentar fornecer somente as informações requeridas pelas especificações, para determinar a aceitabilidade do material, executando as determinações no menor tempo e custo disponíveis. Não constitui objetivo desta apreciaf̧ão apontar us melhores mëtodos de ensaios disponiveis, mas foca lizar a importância dos estudos tecnolögicos e suas atủis limita ̧̧̃os, observardo gue na prática existe a ldéia de uma premencia milto maior na aceiração ou rejeição de um determinado material, mais do que a necessidade de um completo conhecimento de suas pro priedades, levando frequentemente os interessados a práticas mais onerosas.

Em ensaios sobre rochas, para deteminação de suas proprieda des mecânicas, um grande número de mẻtodos foram tentados, incluin do-se entre outros, métocios para determinaç̃o de dureza e, ou re sistência à penetrarão superficial, tenacidade ou resistência ao impacto, resistência ao jesgaste,resistència a esmagamento ou britagem e resistêncịa à abrasão. Muitos contribuições foram também efe tuadas aos métodos de determinação da resisténcia a compressão, re sistência à flexão, resistência à tração e resistêricia ao cisalha mento $(6-23-42-45)$.

Em codos estes ensaios, exceto para us ensaios de abrasăo, des gaste e esmagamento,são utilizados geralmente corpos de prova regl. lares, que são restrictos àqueles materiais a partir dos quais são ostidos os corpos de prova oara ensaio. Embora atë hoje se tenta 
- feito grande uso destes ensaios e apesar de inumeras tentativas de esclarecer os fatores influenciantes, não foi possivel estabelecer um padrão universal satisfatório quanto ao equipamento e tēcnica. Consequentemente, torna-se dificil efetuar uma compara Ção significativa dos resultados obtidos em laboratōrios diferentes. Como exemplo, citamos sigvaidason (42) que mostrou que os re sultados de ensaios de compressão uniaxial, em amostras de concre to identicas, efetuados em cito laboratórios diferentes, apresentaram vastas discrepäncias de resultados, ainda que todos os en saios tivessem sido reallzados conforme os métodos da "British Standards" e da "American Society for Testing and Materials".

Para materiais bitiados, granulares, nas dimensões normalmen te empregadas, foran desenvolvidos diversos mëtodos de ensaios. Um dos principais ensaios mecânicos, que estão neste caso, é o en saio de abrasão Los Angeles (ASTM C-131), reconhecido por todos e constando na maioria das especificações. Além de ser utilizado co mo método para determinar a qualidade de agregados para uso em con creto e pavimentação, encontra sua aplicação na escolha de mate riais para filtros de percolação e enrocamento (4). Neste ensaio, - material rochoso é submetido tanto ao desgaste superficial como a impactos, com este último efeito causando provavelmente a maior parte da perda. Entretanto, em alguns empregos considerados para us materiais ensaiados por este método, eles não são frequentemen te submetidos às forças causando desgaste superficial ou impacto sobre as particulas de agregados como por exemplo, em filtros de percolação e concretos de cimento portland.

A sanidade ou tambēm conhecida impropriamente como resistência ao congelamento e degelo, tem-se constituido em um dos critérios principais para aprovação de agregados. Determinações desta propriedade tem sido efatuadas utilizando-se uma solução de sulfa to de sódio ou magnésio, conforme descrito no método ASTM c88-69. Embora este mētodo esteja atualizado e aceito, a principal difi culdade que apontamos ë a aplicação dos resiltados do ensaio,para um clima como o nosso. Aparentemente não existe correlação.

os agregados rochosos empregados em misturas betuminosas devem possuir dois requisitos principais: seren suficientemente resistentes para aquela finalidade e dever ser capazes de manter a 
cobertura betuminosa contra a ação da água, is to é, devem possuir boa adesividade. O ensaio de abrasão Los Angeles parece ser um meio satisfatório para determinar a resistência do agregado. o en saio normal de adesividade, que consiste na imersão do agregado coberto de betume em āyua e, observação do grau de retenção da. película asfältica por parte do agregado, é diretamente aplicada aos agregados para uso em pavimentos flexiveis. Entretanto, sua aplicabilidade é limitada porque è executada somente na fração grosseira de agregados. Além disso,possivelmente a deficiência mais sẹria é que o resultado deve ser determinado por observaça visual envolvendo então, alta dose de subjetividade. Em vista des. tas limitações sobre a aplicação direta dos resultados de adesivi dade, ocorre uma necessidade de se desenvolver um ensaio que possa medir o efeito da ăgua em misturas betuminosas. Possivelmente, a determinação da resistência à compressão em corpos de prova de misturas betuminosas, que foram submetidas à ação da āgua e a com paração desta, com as resistências de corpos de prova secos,possa constituir-se em ensaio mais adequado para esta finalidace.

Muitos laboratorios de ensaios utilizam os serviços de um petrógrafo para identificar a composição mineral e o tipo de ro cha encontrado em agregados. Embora este serviço seja de valcr inestimävel, acreditamos que o petrögrafo poderia, se soliditado, fornecer informações muito mais completas. Por exemplo, as pro priedades petrográficas de uma rocha são caracterizadas pela:

1. Sua composição mineralögica que ccrresponde à porcentasom dos diferentes minerais que a constituem.

2. Sua estrutura, que definimos aqui como caracteristica da ' dimensão, da forma e da fábrica dos minerais, assin como o fissuramento a descontinuidades que possam existir na rocha.

são estas caracteristicas que intimamente associadas, determinam em grande parte, as propriedades mecânicas das rochas. riorna-se então, cada vez mais desejävel que propriedades como granu1ação, conteüdo em quartzo, grau de cimentação, tipo e grau de . fraturamento, tipo e grau de alteração, possam ser determinadas numericamente para que uma anălise de regressão, possa determinar possiveis correlações analiticas entre estas propriedades geológi cas e os inalces tecnológicos. 
Finalmente, quase todas as especificações emitidas a respeito do emprego de agregados rochosos em concretos e rodovias, apre sentam itens quanto a forma dos fragmentos e presença de substânclas deletérias (silica amorfá, impurezas orgânicas, sulfetos, ma teriais pulverulentos, etc.). Entretanto, raramente são apresenta dos os nomes destas substâncias deletërias e as porcentagens limi tes; admissiveis para estas e para os fragmentos achatados ou alon gados.

Um critério bastante empregado e multo rigoroso, para fragmen tos achatados ou alongados, ē o limite de $5 \%$ em peso ( 4 ). Entretanto, não existe nenhum suporte tećrico ou experimental para a fixação deste limite, senão a suposição de que tais fragmentos possam ser prejudiciais para o uso de agregados. Nos ensaios de abrasão Los Angeles, impacto Treton e esmagamento, a porcentagem de perda aumenta progressivmaente com 0 aumento de fragmentos não císicos $(52)$.

Observamos que no panorama apresentado, foi dado maior atenção àquelas caracteristicas de agregados, cujos campos ainda estão sujeitos a modificações possivelmente radicais, principalmente quanto aos procedimentos de ensaios.

o aspecto da alteração de rochas, merece um tratamento à parte.

A alteração no sentido imprimido por nös, ë o conjunto de mo dificações sofricias pelas rochas na sua composição mineralógica, estrutura e propriedade, quando em uso, como resultado da interação de complexos processos fisicoquímicos. Difere portanto, das alterações deutéricas, hidrotermais, etc, comuns nos processos 'igneometamórficos.

A impnrtância da alteração e desagregabilidade dos materiais rochosus em Engenharia Civil, resiairia principalmente nos seguin tes efeitos $(44)$ :

1. Diminuição da resistência com ou sem produção de finos, ou seja, com ou sem perda de coèsão. A resistência mecânica das ro chas é uma das propriedades que mais vai interessar à Engenharia Civil, ao construtor. Im quaisquer casos, sejam enrocamentos, con cretos, pavimentos, lastros de vias ferreas, fundações, tưneis, a 
diminuição da resistência com a alteração constitui sempre um gra ve inconveniente.

2. Variação nas caracteristicas necânicas de deformabilidade. Sem dúvida, o comportamento geomecânico das rochas, ou na forma de maciço ou agregados, está bastante relacionado ao seu estado de alteração. A importância relativa das vārias fases de deformação depende, não só das características físicas das rochas e das condições de ambiente a que está submetida, como da atuação das solicitações, da natureza destas e das leis que regem as suas va riações.

A deformabilidade de uma rocha é devida de um lado, à deformabilidade do sistema constituído pelos seus grãos cristalinos e, por outro lado, à do sistema constituído pelas ligações entre estes grãos. Cada um destes sistemas contribuiria, ou mais ou menos, para o comportamento global da rocha. Como a alteração afeta tanto a natureza dos grãos minerais como as ligações entre eles, é de se esperax que afete também as caracteristicas de deformabilidade da rocha.

3. Variação na porosidade e perneabilidade e portanto, na es tanqueidade.

A porosidade e permeabilidade das rochas são propriedades re conhecidamente variäveis com a alteração, podendo aumentar ou di minuir $(16-20-21)$. A variação destas propriedades é especialmente importante em obras onde a estanqueidade é fundamental: bar ragens, túneis e fundação.

4. Diminuição nas características de aderência ou adesivida'de tanto a ligantes hidráulicos como betuminosos.

As caracteristicas de aderência e adesividade a ligantes hi draulicos e betuminosos, relacionam-se com o estado de alteração de agregado. A resistência da estrutura,naturalmente deverá relacionar-se com a eficiência desta ligaçäo.

Quando se brita uma rocha, as ligações interatômicas são. quebradas ao nivel da superfície de ruptura. Nos silicatos, que são os principais constituintes das rochas, obtem-se em superfi cie ions posttivos $\left(\mathrm{Ca}^{++}, \mathrm{Na}^{+}, \mathrm{K}^{+}, \mathrm{Si}^{+++}, \mathrm{AI}^{+++}, \mathrm{Fe}^{++}, \mathrm{Fe}^{+++}\right.$, etC. 
e lons negátivos $\left(\mathrm{O}^{=}\right)$. Em presença de água, os cations fixam $\mathrm{OH}^{-}$ e os íons $\mathrm{O}^{=}$fixam $\mathrm{H}^{+}$, para a neutralização da superficie. Numa segunda etapa, os íons superficiais dos agregados tem tendéncia a entrar em solução. A dissolução de $\mathrm{Ca}^{++}, \mathrm{Na}^{+} \mathrm{e} \mathrm{K}^{+}$é mais rápida numa primeira etapa de lixiviação, que a dos ânions sio4 ${ }^{---}$. Assim, as superfícies silicatadas têm tendência a se enriquecer relativamente em silica e em alumina, tornando-se cada vez mais. ācidas, tendendo a uma composição silicosa.

As superflcies deste tipo são mais desfavorãveis a uma boa adesividade dc betume, especialmente se os agregados estão úmidos no momento do lançarnento. A acidificação progressiva das superfícies cristalinas conduz portanto, a riscos de má adesividade a curto ou mädio prazo.

Paralelamente, os agregados constituidos de rochas semialteradas ou alteradas, podem conter hidröxidos de fexro livres ou mi nerais instáveis suscetiveis de fornecerem hidróxidos por lixivia ção, por exemplo, de feldspatos ferruginizados ou da pirita conti da. Os hidróxidos tem tendêrcì a migrar para a superficie do agregado e aí se depositarem, constituindo uma película ferrugino sa desfavorävel a uma boa aderência entre a rocha e o ligante, so bretudo para os prë-misturados a frio.

De um modo geral, as causas que determinam a alteração per tencem a duas grandes categorias: (11-14-38-44):

1. A primeira agrupa as causas ditás externas, que caracteri zam o ambiente de alteração e se nanitestam, qualquer que scja a natureza da rocha.

2. A segunda compreende as causas ditas internas, que são ji gadas às características intrínsecas das rochas e determinam sua alterabilidade.

As causás externas são inicialmente processos fílicos liga .. dos sobretudo às variações de temperatura e umidade, e que conduzem a uma desagregação mecânica majs ou menos forçada das rochas. Esta desagregação mecānica é caracterizada por:

1. Fragmentação em blocos angulosos, de rochas coerentes:cex tos calcários, muitos basaltos e rochas cristalinas de granulação fina em geral. 
2. Escamação de rochas em placas desde alguns centímetros a milímetros de espessura.

3. Esfarelamento em rochaji granulares ou grãos de areia: al gumas rochas cristalinas.

A partir do apaxecimento destas aescontinuidades é que inter vem geralmente os processos quimicos. Eles se traduzem por um ataque dos minerais das rochas por soluções mais ou menos agressi vas, que penetram e circulam nos materiais, com tanto maior facilidade quanto maior for o efeito dos processos físicos. Ās vezes, a alteração é ainda acentuada por fetores bjológicos que atuam,ou diretamente por ação mecânica su indiretamente aumentando a agres si.vidade das soluções.

Uma roch a é definida por um certo numero de caracteristicas, algunas ligadas à sua origen e outras resultantes de transforma ções sofridas ao longo de sua histōria geolögica. Em condições am bientais idênticas, as rochas não se alteram da mesma forma. Cada uma delas e caracterizada por uma certa olterabilidade que depende:

1. Ea natureza dos contutuintes: composição química e mineralogia.

2. De suas características texturais, estrutura, granulação, grau de uimentação.

3. Das modalidades de penetração e circulação do agente 1 i quido agressivo, ao interior da rocha, que dependem por sua vez, da porosidade e fissuração.

Como vinos, uma análise adequada das causas e mecanismos da , alteração e seus efeitos nas propriedades fisicomecânicas, é extre mamente importante para uma avaliação do estado de alteração: e previsão do comportamento de rochas, seja como maciço rochoso seja como agregado. Nos casos rotineiros, esca avaliação tem sido usualmente efetuada cie maneira bastante empirica, fornecendo so mente uma idéia qualitativa do estado de alteração. A falta do estabelecimento de métodos quantitativos para a estimativa aa alteração meteórica, tem permitido se chegar a determinações subjetivas e nem sempre corretas. Por esta razão, a tarefa de encon trar mētodos quantitativos mais objetivos para estimar o grau de 
alteração e alterabijidade de rochas se torna extremamente importante. Os principais problemas de um estudo de alteração de rochas e sua avaliäção, consistem nos: seguintes:

1. Procedimento de cálculo da variação da resistência e esco Iha do parâmetro mecânico.

2. Infiliência da granulometria para ensaio.

3. Correlações entre resultados obtidos em ensaios de labora tório e aqueles referentes à desagregação de rochas no campo.

4. Validade e aplicabilicace (significado físico dos ensajos de alteração).

Diversos procedimentos foram até hoje propostos para avaliar o comportarlento de rochas face à alteração. A maioria deles deter mina a qualidade da rocha no momento da anälise constituindo-se em avali ações qualitativas de seu estadu atual, não fornecendo uma previs̃o quanto ao comportamento mecànico das rochas. Citaremos resumidamente alguns dos orocedimentos mais importantes:

1. Morais Rego, L.F. e Souza Santos. T.D. (31) - sugeriram a porostade aparente como indice de durabilidade. Em anostras de una mesma rocha, a mais alterade deverá apresentar maior purosia de aparente, portanto inenor durabilidade.

2. Hichler, E. ( 33 ) inăica a análise petrogräfica e o en saio de abzurção d'ägua sob pressão normal como critério de preví são da alterabilidade de rochas. Determina-se a porcentagem de água abscrida por amostras representativas. Se a análise petro gräfica indicar is rocha como possuindo alteração pronunciada e o valor dá absorção d'água superior a $0,5 \%$, esta é de mä qualidade ie deve ser rejeitacia.

3. Talobre, J.A. (45), sugere um ensaio de alteração acelerada em laboratório, como critéric de avaliação da alterabilidade de rochas. Os ataques são aceleradois em corpos de prova em pö e cilíndricos de $1 \times 1 \times 2 \mathrm{~cm}$, por mejo do ácido sulfúrico 10\% a quente. As perdas de peso das rochas em pó e dos corpos de prova cilínäricos são determinadas apōs $1 \mathrm{~h}, 3 \mathrm{~h}, 5 \mathrm{~h}$ e / $\mathrm{h}$ de ataque. São considerados como admissíveis perdas de $18 \%$ após 7 horas para o pó e de $100 \mathrm{mg}$ sobre os corpos de prova cilindricos.

4. Segundo Rocha, M. (38), no Laboratörio Nacional de Engenha 
ri

a Civil (Lisboal, está sendo seguida técnica que consiste em moer a rocha, para uma dada granulometria, e em submetê-la a percolação contínua de água quente dentro do tubo extrator soxhlet. Toma-se como critério de alterabilidade a perda em peso da rocha num dado tempo de ensaio.

5. Iliev, G.I. (25), examina a influêncịa do intemperismo nas diferentes propriedaães fisicomecânicas e recomenda usar a mais variāvel delas como indicadora da alteração, encontrando a velocidade de propagaçăo de ondas ultrasônicas como o melhor indi ce. Introduz com hase nesta propriedade, um coeficiente de altera ção: $K=\frac{V O-}{V} c$ conde $V o$ e $V_{W}$ são respectivamente a velocidade de propagação je ondas uıtrasônicas em uná rocha fresca e aiterada)!

6. O Idaho Department of Highways (24) apresenta um mëtodo de ensaio para anālise da àsagregação de rochas. Consiste em um ensaio de abrasão modificado (sem carga abrasiva)e sob a ação de um compactador. A iriterisidade e tipo de desagregação são indicades por mudanças nos valores äo grau de seleção,Iimite de liquidez, ín dice de plasticidade e equivalente em arei a em relação ao mate rial original.

7. Scott, I.E. (in 14), recomenda a execução de anälise petrográfica de agrezados basálticos. Teores superiores a $20 \%$ de minerais secundärios situarian a rocha fora de especificaçũes.

8. Day, H.I. ( 11 ), propõe um mätodo de ensaio para previsão da desagregação de rochas basaltivas, baseado em valor Deval modi ficado e anälise granulométrica dos finos obtidos. Propõe ainda uma classificação da qualidade de basaltos, tendo em vista o con. ,teūdo em minerais à alteração verificado numa anälise petrográfi ca: 0 a 15\% - boa qualidude, $15-25 \%$ de transição e mais que 25\% de qualidade inferior.

9. Schiejder e Pires da Rocha (41) propõem uma anälise pe trogräfica para determinação das porcentagens de minerais secundä rios em rochas hasálticas, com emprego eln pavimentação asfáltica:

a. Se a rocha contiver menos de 5\% (em volume) de minerais secundạrios deletërios, dispensa-se a execução de ensaios adicionais e a rocha pode ser aceita.

b. Se a Irocha contiver de 5 a $10 \%$ de minerais secundários e 
'estes forem do tipo não expansivo (caulinita,ilita, etc.), pode a mesma ser utilizada, sem ensaios adicionais.

c. Se a rocha contiver de 5 a $10 \%$ de minerais secundarios e esses forem do tipo expansivo, deve a mesma ser submetida a en saios.

d. Se a rocha contiver mais que $10 \%$ de minerais secundários, deverá a mesma ser submetida a uma série de ensaios.

10. Krauskopf, K.B. (in 14), define numericamente o grau de alteração mineralögico ol geoguímico de uma rocha, utilizando-se de dados químicos:

$$
K=\frac{\text { no de moles }\left(\mathrm{CaO}+\mathrm{MgO}+\mathrm{Na}_{2} \mathrm{O}+\mathrm{K}_{2} \mathrm{O}-\mathrm{H}_{2} \mathrm{O}\right)}{\text { no de moles }\left(\mathrm{SiO}_{2}+\mathrm{Al}_{2} \mathrm{O}_{3}+\mathrm{Fe}_{2} \mathrm{O}_{3}+\mathrm{CaO}+\mathrm{MgO}+\mathrm{Na}_{2} \mathrm{O}+\mathrm{K}_{2} \mathrm{O}\right.}
$$

o valor desta expressão aiminui à medida que a alteração aumenta na rocha.

11. Muitos autores são particularmente interessados no estudo de descontinuidades em rochas, que eles consideram como um fa tor primordial nos fenomenos de alteração (Goni, J et al-1968; Thenoz, B. et al - 1966; Farran, J: et al-1965).

Eles classificam as descontinuidades em duas categorias prin cipais: as fissuras que constituem a microfissuração matricial (es pessura $\leq: 1 \mu$ ) e são representadas pelas clivagens e fissuras in tragranulares e às vezes fissuras intergranulares. a nivel da microfissuração matricial que se situam essencialmente as grandes superfícies de contato entre uma rocha e um fluido. A segunda ca , tegoria inclui as fraturas, que são em muito menor número que as fissuras matriciais, distinguindo-se microfraturas (espessura s $0,1 \mathrm{~mm}$ ) e as macrofraturas (diaclases, falhas).

o estudo do macrofraturamento se faz sobre a rocha "in situ", à escala do afloramento ou maciço rochoso, zo passo que, o do microfraturamento e da microfissuração matricial, resultam do exame mi croscōpico de seç̧ões delgadas de corpos de prova previamente impregnadas por uma resina colorida. A partir dos resultados de ensaios de permeabilidade e porosidade relativa da rocha, pode se calcular a superficie desenvolvida dessas descontinuidades. ES ta superficie, relacionada à unidade de volume (ou de peso) do ma 
'terial considerado, é chamado de "superfície interna unitária" e constitui um critério de alterabilidade, para rochas com permeabi lidade $>0,1 \mathrm{mdy}$.

12. West, T.R. e outros (50), propõem procedimentos incluin do anālises petrográficas macroscöpicas e microscópicas, ensaio de abrasão Los Angeles seco e úmido, congelamento e degelo. Estes ensaios são combinados conforme a natureza petrográfica e relacio nados a um indice de alteração, fixado pelos autores e que varia de 0 a 10.

13. Aires-Barros, L.A. (1-2), estabelece o chamado Indice de qualidade micropetrogräfico, que é determinado a partir de uma relação entre minerais sãos e minerais alterados e relacionado a grandezas rnecâri icas como o módulo de elasticidàde e a tensăo māxi ma de ruptura.

14. Lockart, J.H. e Marchetti, C.F. (in 24) propõem um indice de degradação, para emprego de agregados de quaiidade inferior em rodovias. O Indice de degradação é a soma dos deslocamentos ra curva granulométrica, após compactação, com um compactador giratö. rio. O material aceitável para base deve possuir ID $\leq 7 \%$.

15. Para Farran J. et a1 (16), o primeiro parâmetro determi nante a levar em consideração é a permeabiiliade da rocha e não a superficie interna que intervem somente en seguindo lugar. Em. função de sua alterabilidade, classificaram as rcchas em duas grandes categorias:

a. Rochas muito compactas onde a circulaçäo de ägua é impossivel.Granitos desta categoria, quaisquer que sejam a sua superfi cie interna e sia alterabilidade, são praticamente inalterāveis.

b. Rochas menos, compactas, no interior das quais as circuiações de āgua são impossíveis. Para estas, a alterabilidade se revela então proporcional à superfície interna unitäria.

A alterabilidade para estes autores, è definida pela alterabilidade especifica que é a relação entre a porcentagem de argilo minerais expansivos e a velocidade de alterção (\% perda em peso) tempo)

16. Struillou, R. (44) propõe o mëtodo de imersão de fragmen tos de rocha de $10-20 \mathrm{~mm}$ em água oxigenada a 110 volumes,

para 
caracterizar a sensibilidade de uma rocha à desagregação. A por centagem que passa na peneira de $8 \mathrm{~mm}$, apös ensaio, constitui o critërio de previsão que se utilizará para comparar o material es tudado com outros materiais empregados em obras equivalentes.

17. Weinert, H.H. (43) estabelece um fator climätico (N), que representa a expressão numërica das condições climāticas de uma determinada ärea. Este valor é obtido relacionando-se a evapo transpiração do mes de maior pluviosidade com a precipitação anual. Este fator climätico é posteriormente relacionaao à porcen tagem de minerais secundarios, obtendo-se uma iinha que separa as rochas sãs das rochas alterauas, para efeito de aprovação de mate riais para finalidades rudoviardas.

18. Hamrol, M. (22), sugere o processo da saturação de amos tras de rochas em água como uma indicação de alteração. Estabelece dois parâmetros: $i_{I}$ e $\dot{i}_{I I}$.

$i_{I}=$ alteração scluindo fraturamento de qualquer natureza

$i_{I}=$ aiteraçăo consistirdo exclusivamente de fraturamento

O valor numërico de $i_{I}$ é a $\%$ de ăgua absorvida pela rocha em um ensaio de absorção, dividida pelo seu peso seco:

$$
\begin{aligned}
& i_{I}=\frac{P_{2}-P_{1}}{P_{1}} \cdot 100 \\
& P_{1}=\text { peso seco } \\
& \mathrm{P}_{2}=\text { peso } \text { saturado }
\end{aligned}
$$

o valor numérico ì é dado pela expressão:

$i_{I I}=\left(\alpha x+\alpha y^{\prime}+\alpha z\right) 100$ onde $\alpha x, \alpha y$ e $\alpha z$ representam as $d i-$ merisós lineares das aberturas de diaclases ao longo de 3 eixos ortogonais, pela unidade de comprimento. Representa grosso modo, - Indice de vazios.

Dividindo-se a mudança dos parâmetros $i_{I}$ e $i_{I I}$ pelo intervalo de tempo consideraâo, obtem-se a alterabilidade áas rochas.

19. Recentemente Farjallat, J.E.S. (14), propõe una expressão matemätica para exprimir e alterabilidade de uma rochá dentro 
'de um intervalo de tempo $\Delta t$, representando este, o intervalo tre dois estágios de alteração natural ou experimental:

$$
K_{(\Delta t)}=1-\frac{200-F}{200-I}
$$

onde:

$I=$ valor Los Angeles no tempo inicial do intervalo $\Delta t$, mais \% desagregada até então

$F=$ valor Los Angeles no tempo final do intervalo, mais \% desagregada até então.

O valor 200 é utilizado como limite para o qual tende $I$ a F. - coeficiente de alterabilidade $K$ pode variar no intervalo 0 a 1 . Quanto maior o seu valor, maior é a alterabiliāade da rocha. 
III. - METODOLOGIA EMP REGADA

III.I - Amostragem e métodos

Tendo em vista as dificuldades na obtenção

de

grandes volumes de amostras necessārias para o desenvolvi mento de uma pesquisa desta natureza, procurou-se estudar tipos litológicos característicos levando em conta sua dis ponibilidade em quantidades adequadas, bem como o interes se imediato existente sobre o conhecimento de suas pro priedades tecnológicas, para seu aproveitamento como fontes naturais de materiais de construção. Assim, escolneuse amostras caracteristicas entre as rochas igneas, metamörficas e sedimentares de pedreiras em franca exploração ou de locais de implantação de obras de grande porte.

As amostras estudadas constituiran-se de:

A) Iragmentos de rocha de dimensões varianäo de blocos de décimos de metros cübicos a alguns centimetros cübicos, provenientes de britagens primärias nos locais de origem.

B) Testemunhos de rocha de locais onde se estudam ou se constroem obras civis, obtidas a partir de sonda gens rotativas de diversos djametrus, com coroa de diaman te.

c) Britas constituías da aiversas granulometrias obtidas na saida de britadores prinerics ou de silos cie pedreiras.

Estes materiais apös a recepção, foram separados a partir de uma observação macioscōpica grosseira, confor me as suas caracteristicas patrograficas, em unidades litológicas diferentes para efeito de ensaio. As amostras enviadas, considercdas macroscopjcamente homogâneas, fo ram diretamente levadas para preparação de corpos de prova, infelizmente sem quarteanento, devido à quantidade restrita de materiais aisponiveis em relação ao volume de ensaios. Para contornar este inconveniente, o no de en saios executados foi duplicado ein relecão ao no de ensajos 
prescrito pelos mëtodos seguidos. As dispersões observa das foram perfeitamente tolerăveis (abaixo de $10 \%$ ).

Os materiais recebidos șob a forma de blocos de pecira ou testemunhos de sondagem, permitiram obter corpos de prova prismáticos de $5 \times 5 \times 10 \mathrm{~cm}$; cúbicos de $2,5 \times 2,5 \times 2,5 \mathrm{~cm}$ e cilindricos, para os ensaios de com pressão simples axial, impacto com o aparelho de impacto da ASTM e com o esclerômetro schmidt. Essas serragens fo ram efetuadas em máquina de corte de pedra com discos de carborundum, que foram suficientemente eficientes para não caussrem a ruptura nem o fissuramento dos corpos de prova. os blocos de pedra permitıram, tambëm, a obtenção de corpos de prova cilindricos de diversas dimensöes, com - emprẹco de uma perfuratriz de laboratório, da Acker DriIl. Co., Inc.

Fara os demais ersatos, que recuerem pedra britada, as graduações de erısaio foram obtidas por britacjem ma nual das amostras recebidas.

Todas as rochas foram submetidas a uma caracterização techologica inicial que compreendeu os seguirtes en saios e mëtcdos adotados ( 39$)$ :

A) Parâmetros ae dersidade: massa especifica aparente, absorção d'ägua e porosiaade aparente.

- Mëtrdo de ensain IPT M-47.

B) Resiscência ao impacto Treton

- Mëtodo de ensaio IPT M-52.

c) Resistência ao esmagamento

- Mētodo de ensaic IPT M-53

D) Resistêrıcia à compressão simples axial

- Mëtodo de ensaio IPT M-50

E) Resistência à abrasão Los Angeles

- Método dé ensaio ABNT M-170

para os ensaios com o esclerōmetro schmidt, o apa 
relho de impacto ASTM D3-18 e o aparelho de desgaste a ümido, foram efetuadas uma série de ensajos com grande vo lume de amostras, para que os dados de reprodutibilidade do equipamento e dimensionamento de amostras tentiam validade estatística, bem como suas possiveis correlações, com as demais propriedades, obtidas nos ensaios acima citados Os resultados alcançađos permitiram a elaboração de uma proposta de método para os ensaios de desgaste a ümido e ensaio com o esclefómetro schmidt, bem como um método modificado para o ensaio com o aparelho de impacto D3-18.

ITI.2 - Procedências e tipos de amostras

Para facilitar a identificação durante o andamento dos estudos, as amostras foram simplesmente indicadas pela sua designação petrogrăfica e local de origem. A descrição petrogräfica detalhada, efetuada pela seção de Petrografia do Instituto de Pesquisas Tecnolögicas, encon tra-se no Apênaice A deste trabalho.

As amostras estudadas foram as seguintes:

AMOSTRA NO 1

Basalto "A" da Barragem de Capivara, proveniente de pedreira da margem direita, Rio Paranapanema. A amos tra e constituída de blocos de basalto compacto, de textura afanitica e cor cinza-mëdio esverdeado, do derrame I (14-15), do local da barragem.

ANOSTRA NO 2

Basalto "B" da. Barragem de Capivara, proveniente do local da escavação do vertedouro da barragem, no Rio Pa ranapanema. A amostra é constituida de blocos de basalto vesiculo-amigdaloidal, caracteristica de topo e base do dexrame II ( 14$)$, do local da barragem.

AMOSTRA NO 3 .

Basalto "C" da Barragem de Capivara, proveniente do local da escavação do vertedouro da barragem, no Rio paranapanema. A amostra é constituida de blocos e tescema 
nhos de sondagens rotativas, de basalto microamigdaloidal com amigdalas preenchidas por minerais argilosos esverdea dos a amarelados, do derrame II (14-15), do local da barragem.

\section{AMOSTRA NO 4}

Basalto de Salto osónio, proveniente da pedreira da barragem de Salto osório, Rio Iguaçu, Estado do Para nă. A amostra é constituraa de blocos de basalto vesicu loamigaloidal, com amigdalas preenchidas por minerais ar gilosos €sverdeados, cirartzo e zeölitas, de textura afaní tica e coz cinza acastanhado.

AMOSTRA NO 5

Easalto de Olimpia, proveniente da Pedreira Jazida, em exploração, no Municịio de olímpia, Estado de são Pau10. A amostra é constitulda de blocos e pedra britada de basaito compacto, de teytura afanitica e cor cinza esverdeado.

AMOSTRA NO 6

Basalto da Serra de Srotas, proveniente de uma pe Creiza em exploração, entre os Nunicipios de Dois Cōrre gos e Guarapuã, no Estado de São Paulo. A amossra é constituída de blocios e pedra britada de basalto compacto, de textura afanícica e cor cinza escuro a preto.

AMOSIRRA NQ 7

Basalto da Ina Solteira, proveniente da Pedreira $B$, da maxgem esquerda do Rio Parana, nas proximidades da barragem de Iiha soltejra. A amostra e constituida de blocos e testemunhos de sondagens rotativas de basalto compacto,..de textura afanitica e cor cinza escuro.

AMOSTRA NQ 8

Diabásio Campinas, proveniente da Pedreira Pedrabrasil, em exploração, no km 97 da via Anhanguera, Munici pio de Campinas. A amostra é constituida de blocos de dia básio, de textura afaritica fina, de cor cinza escuro. 


\section{AMOSTRA NQ 9}

Quartzito Jequitai, do local da barragem do Rio Jequitaí, Municîpio de Jequitäi Estado de Mirıs Gerais. A amostra é constituida de testemunos de sondagens rotativas de quartzito maciço silicificado, de cor cinza claro.

\section{AMOSTRA NO 10}

Calcărio do Rio Grande do Sul, proveniente de uma pedreira no Estado do Rio Grande do SuI. A umostra é cons titứa de blocos de calcario de textura cristalina, de cor cinza claro.

\section{AMOSTRA INO 11}

Calcário Apiaí, proveniente de uma pedreira no Município de Expiaí, no Estado de São Paulo. A amoscra é constituida de blocos ce calcário de textura cristalina, de cor sinza claro.

\section{AMOSTRA NOS 12 e 13}

Granito Arhanguera, (São e Alterado), proveniente à Pedreira Anhznguera, em exploração, no $\mathrm{km} 22$ a a via Anhanguera, Cajamar, Eștado de Sz̃o Paulo. As amostras são constituidas de blocos de granito gnáissico são e levemen te alterado, de textura por vezes orientada, de cores cin za clarc e amarelado.

\section{AMOSTRA NO I4}

Charnockito ubatuba, proveniente da Pedreira do Perequê-Mirim, no Municipio de Ubatuba, Estado de são Pau 10. A amostra e constituícia de blocos de charnockito, de textura grossa, de cor cinza esverdeado.

AMOSTRA NO 15

Piroxenito Niquelândia, proveniente de um atioramento no maciço de Canabrava, Municipio de Niquelândia, ss tado de Goiás. A amostra é constituída de blocos de piroxenito, de textura média, de cor verde amarelado. 
AMOSTRA NQ 16

Granito Sacos, proveniente da pedreira da barra gem de Sacos, no Rio Formoso, Estado da Bahia. A. amostra é constituída de testemunhos de sondagens rotativas de granito, de textura média, de cor rósea.

AMOSTRA NO 17

Migmatito Jaborandi, proveniente da pedreira da barragem de Jaborandi, no Rio Formoso, Estado da Bahia A amostra $e$ constituida de testemunhos de sondagens rotativas de migmatito de textura fina a média, de cor cinza röseo.

AMOSTRA NO 18

Arenito Bauru, proveniente de um corte de estrada na ligação ferroviāria Bauru - Garças, no Estado de : são Paulo. A amostra é constituida de blocos de arenito calci fero maciço, de cor avermelhado claro.

III. 3 - Aparelhagem

Para o desenvolvimento desta pesquisa, foram ne cessários os seguintes equipamentos:

A) Britador de mandibulas com abertura minima de $2,54 \mathrm{~cm}$ da Fäbrica de Aços Paulista S.A.

B) Aparelho de extração de corcos de prova da Acker Drill Co., Inc., com jogo de corpas diamantadas de diversos diâmetros. rundum.

C) Serra para corte de rochas com discos de carbo-

D) Mãquina Los Angeles conforme AASHO T96-56.

E) Mäquina Treton do padrão DER: P81-52T.

F) Prensa Amsler de 200 toneladas para os ensaios de resistência ao esmagamento e compressão simples axial.

G) Mãquina de impacto para corpos de prova moldados, construido pela Divisão de Mecânica, do Instituto de 
Pesquisas Tecnológicas, conforme ASTM D-3-18.

HL Esclerômetro Schmidt, modelo RM-710 da Soil test Inc.

I) Aparello de desgaste a úmido, desenvolvido pelo Imperial College de Iondres e fabricado nas oficinas da Dirisão de Mecânica do Instj.tuto de Pesquisas Tecnolögi. cas, a partir dos dados constantes no trabalho de Frankiin $(17-18)$.

J) Micros cópio pétrográfico ortrolux da leitz Wetzlar.

K) Estufa ventilada da FANEM, modelo $315 / 5 \therefore$ com termostato com capacidade de manter uma temperatura constante de $105-110^{\circ} \mathrm{C}$.

I) Conjunto extrator Soxhlet com manta aquecedora e cegulador de voltagem.

Mi) Calculadora 9810 A HE da Hewlet - Packard, com capacidade para 500 steps (passos de prosrama) e 51 regis tros para armazenamento de dados os quais podem ser exten didos para 2036 steps e 111 registros através da extensão de menöric (plauqueta colocada no irterior do aparelho). Apresenta ainda uma impressora (termo-sensivel) e leitora de cartóes magnéticos, amios colocados no interior do apa retho. Consta de blonos anceixáveis nas suas tampas superiores (o bloco estatistico permite calcular os parime tros estatisticos e efetuar a anälise de regressão). 
IIV. - ENSAIOS FISICOS ESTUDADOS

IV.1 - Avaliação da resistência de rochas pelo emprego do esclerômetro schmidt.

o esclerômetro Schmiat é. um instrumento de campo em pregado normalmente na determinação da resistência à compres são de concretos (27-28). Una grande experiênci a foi acumu lada por duas dēcadas existindo ainda äiscussões a respeito de seu emprego. um recente apanhado da opinião internacio nal (2q) estabeleceu que o esclerômetro fornece somente una inalcaça grosseira da qualjaade jo concreto mas tem sido contudo, de grande utilidade nesta avaliação.

o instrumento consiste basicamente de lim pistão com nola que é projetado contra uma pequena bigorna que estä em contato com a superfície da amostra ensaiada. o pistão ao ricochetear após bater nesta bigorna, è travada por um bo tão, e a altura de retôno é indicada sobre uma escala graduada subdividida em intervalos iguais de 0 a 100 , que è de nominado de Indice escleromëtrico, dureza escleromëtrica ou valor de recorno schmiat.

A ação destes instrumentos teni sido considerada como uma boa simulação da açz̃o de ferramentas de perfuração a percussão servindo, portanto, como inäicadoras da perfurabi lidade de rochas $(51)$.

Alguns autores como white (5l) e Leere (12), correla cionaram com certo sucesso, os resultados obtidos com estes instrumentos aos valores ce resistência a compressão, módulo de elasticidade e coeficiente de Poisson, obtendo roeficientes de correlação dä ordem de 0,7 a 0,9 . o segundo au tor acima citado, elaborou um äbaco a partir dos resultados de 28 rochas diferentes, que permite estimar a resistencia à compressão e mödulo de elasticidade de uma rocha, conheci dos os valores do Indice esclerometrico e massa especifica aparente, com no mínimo $75 \%$ de certeza, o que constitui uma razoàvel estimativa, dada as características de heteroge neidade destes nateriais. 
rochas, foj praticamente comprovada por estes autores. Alëm disso, tratamse de um ensaio bastante simples, não destruti vo, rápido, de boa reprodutividade e razoável precisão ( da orảem de no māximo 15\%).

Em nossos estudos procuramos testar esta aplicabilidade através da execução de diversos ensaios, que nos permi tissem obter as variäveis de ensaio, afim de elaborar um mé todo para emprego deste instrumento em ensaios rotineiros. Um outro objetivo é o da verificação da validade do Inaice esclerométrico como parâmetro do estado de alteração.

o instrumento empregado foi o esclerômetro schmidt, modelo RM-710 da solitest, Inc., com energia de percussão -. de $0.225 \mathrm{kgm}$, cuja descrição dẹtalhada encontra-se no Apêndice $B$ deste trabalho.

As variāveis de ensaio investigadas foram: dimensões do corpo de prova, tipo de suporte, no de leituras, preci são, sistema de ensaio e correlações com diversis proprieda des tecnolögicas.

O estudo da validade do Indice esclerométrico como parâmetro do estado de alteração foi efetuado em laborató río, com a realização de ensaios em corpos de prova de dife rentes rochas, submetidos à alteração por liwivieção contí nua em extrator soxhlet e, no campo, com a realização de leituras sistemáticas mensais, nas paredes da escavação da tomada d'água da barragem de Capivara.

Apresentamos a seguir, os procedimentos adotacios e os resultados obtidos por partes:

A) Estudo das variáveis de ensaios

Através' de serragem e com o auxílio da perfuratriz de laboratório, foram preparados corpos de prova de diversas dimensões, de diferentes rochas.

Para encontrarmos a dimensão mais adequada para : 0 corpo de prova, foram efetuadas 30 leituras para cada 2 cor pos de prova de dimensões variando de $2 \mathrm{~cm}$ a $8 \mathrm{~cm}$ de espessura e diâmetro constante $7,05 \mathrm{~cm}$. As leituras foram toma das nas faces transversais. Os resultados obtidos indicaram 
que para espessuras maiores do que $7 \mathrm{~cm}$ não hà interferên cia do tipo de suporte do corpo de prova para ensaio. As dispersões dos resultados sofreram uma queda sensivel, com - aumento da espessura do corpo de prova (o coeficiente de variação caiu de $37 \%$ a $19 \%$ ).

Chefdeville ( 8 ) utilizando o esclerômetro Schmidt em concretos, verificou a existência de uma irffluência considerāvel do substrato de apoio dos corpos de prova, sobre os resultados obtidos. Este fato foi comprovado em nossos ensaios, efetuando-se 30 medidas em corpos de prova apoi a dos sobre o suporte da Soiltest (que acomenha o instrumento), e sobre apoios diferentes construidos em nosjas ofici nas (apoio de ferro fundido e apoio de madeira). A corlearação entre as dispersões obtidas demonstrou que cs ensajos sobre o apoio soiltest apresentam um menor coeficiente de variação, da ordem de $5 \%$.

A precisão ou yrau de concoraancia entre resultados repetidos obtidos sob qualquer conjunto definido de condi. ções, è geralmente expresso como um èrro relativo. Um aumen to na precisão implica em um decréscimo no seu valor ruméri co absoluto. Para a determinação da precisão de ensajo de

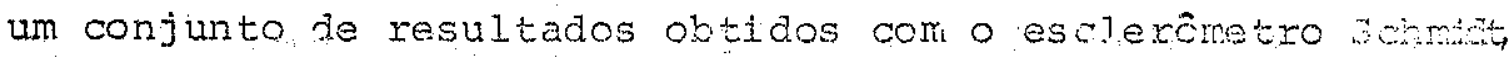
foram efetuadas 30 medidas em corpos de pcova priancices de diferentes rochas, nas faces transversais, distanciadas de $10 \mathrm{~cm}$. O maior erro relativo da média obtido foi de 0,7, que corresponde a um coeficiente de variação de $14 \%$ e des vio padrão de 4,2. Para efeito de dinensionamento de mos tras ou seja, o no minimo de ensaios necessários para se atingir $95 \%$ de, confiança nos resultados, foi considerada es ta aispersão máxima pois, os demais ensaios deverão prova velmente cair dentro desta faixa.

Iliminando-se a dispersão cevido ao equipanento, obtida com a execução de 30 ensaios en corpos de prova teuricamente isotrópicos (gesso, cajda de cimento, vidro), da dispersão acima obtida, calculoumse que são necessários no mínimo 5 leituras individuais, para se obter uma boa média representativa de um determinado ensaio, com um erro relati. 
vo inferior a $15 \%$ no valor da mëdia.

As observações revelaram que poderão ocorrer 2 valores do indice esclerométrico possíveis de serem obtidos para uma determinada rocha, um valor inferior ou inicial. e um valor superior ou mäximo quando efetuamos diversos en saios em um ponto. o valor inferior é o primeiro a ser ohti do em um ponto de ensaio. A repetição de ensajos sobre este mesmo ponto mostrou frequentemente valores crescentes at que um máximo foi obtido. Este aumento de valores incicaria um endurecimento superficial do corpo de prova. Este aspecto não é apresentado devido à insuficiencia dos dados que dispomos e deverä ser investigado oportunamente. Constituirá eventualmente, em um novo sisterna de medida dos iruicés. esclerométricos.

Obtidas as variáveis de ensaio, procedeu-se à deter. minação do Indice escleromētrico de aiversas rochas, cujos resultados estão apresentados na tabela 1 .

B) Anālise dos resultados

Estes resultados foram analisados através do mëtodo de regressão pelos minimos quadrados, para oetermiriação de re lações porventura existentes entre Indice esclerométrico e outras propriedades tecnologgicas. As equaçöes de correlaçãc encontradas, consịderando-se sempre o Indice esclexométrico. como variável independente, ercontran-se na tabela 2.

A seguinte codificação fo: estabeleçida para ᄏs equa ções de regressão:

$$
\begin{aligned}
& \text { IE - Indice Escleromētrico } \\
& \gamma \text { - Massa Especifica Aparente } \\
& \text { A - Absorção d'ägua } \\
& \text { PA - Porosidade Aparente } \\
& \text { ALA - Abrasão Los Angeles } \\
& \text { E - Esmagamento } \\
& \text { Im - Impacto Treton } \\
& \text { CSA - Compressão Simples Axial }
\end{aligned}
$$

Foram calculadas para cada equação de correlação, os 
respectivos coeficientes de correlação e erros padrão de es timativa. o coeficiente de correlação fornece uma indicação da correlação relativa e.tre variạveis e o erro padrão de estimativa constitui uma medida da variância em torno da linha de regressão. Maiores detalhes sobre o procedimento estatístico adotado, encontram-se no Apênaice C.

Os välores dos indices esclerométricos em relação às propriedades tecnolöglcas, foram colocadas em gräficos e en contram-se nas figs. $1 \in 2$, onde foram traçadas a linha de regressão com os respectivos limites obtidos pelos erros pa drão dos valores estimacios. Escolheu-se a relação linear pe la maior facijidade de interprecação e pela proximidade dos valores dos coefiaientes de correlação das vārias relações.

Os resultados da anälise de regressão indicam que. existem poucas correlações eitre o Incice esclerométrico e as propriedades tecnológicas. Existe unia correlação signifi cante entre o Indice escleromëtrico e os valores da ahrasão ios Angeles e os da Compressão simples Axial. Esta ültimacorrelação é significativamente malhorada quando muttiplica mos o valor do indjce esclerométrico com a massa espedifica aparente, o que conconda com os resultados obtidos por Deere (I2).

C) Parâmetro do estado de alteração

A aplicabilidade do ensaio com o esclerômetro schmict, como medida do estado de arter ação de cochas, foi estudada da seguirte maneira:

1. Laboratōrio

Foran preparados inicialmente 4 corpos de prova pris máticos de $5 \times 5 \times 10 \mathrm{~cm}$ de caca rocha estudada, sendo que ein 2 deles foram efetuadas 10 medias em 10 poitos de uma face, e 10 a 20 medidas repetidas em diversos pontos das de mais faces. Obtivemos assim, uma mádia dos 10 pontos ini ciais e uma outra média (geralmente mais elevada), resultan te das medidas repetidas em cada ponto. A seguir, os 2 corpos de prova restantes, foram submetidos a 30 ciclos de 1 i xiviação continua no extrator soxhlet e posterior secagem - 
em estufa a $100-110^{\circ} \mathrm{C}$. O material seco, após alteração, foi submetido ao mesmo procedimento com o esclerômetro schmidt; obtendo-se da mesma maneira, 2 medias diferentes menores pa ra cada caso descrito acima.

\section{Campo}

Os ensaios com o esclerômetro schmidt no campo, foram efetuados pela seção de Geologia Aplicada do Instituto de Pesquisas Tecnológicas, nas parecies da escavação da toma da d'āgua e tubulação, da barragem de capivara. o procedi mento adctado foj o seguinte:

Inicialmente foram escolhidas äreas de $1 \mathrm{~m}^{2}$ em diver sas paredes constituidas de basaltos do tipo "C" e "B", on de foram locados 25 pontos em cada ärea. A seguir, foram executacios mensalmente, 5 ensaios em cada ponto, perfazendo um total de 125 pontos por ärea, para se ter uma média do indice esclerométrico para cada ärea. As observações indicaram que ocorreu uma queda nas médias obtidas, de aproximada mente $I \%$ ao mès, aliada à visivel alteração superficial das paredes.

Como vemos, ocorre unà queda sistemätica tanto no campo como em laboratörio, do valor do indice esclerométxico, quancio as rochas são submetidas à alteração. Este fato indica que o ensaio com o esclerômetro schmidt poderá constituir-se em un método promissor para a obtencão de um parâ metro do estado de alteração. Entretanto, somente apos .. a padronização de um sistema mais adequado de medida, e que poder-se-á aplicar este indice em caracterizações tecnológi. cas rotineiras. Para tal, elaborou-se um método que pocierá comparar os resultados destes procedimentos (Apêndice B).

D) Conclusões

As conclusões preliminares para emprego do esclerône tro schmidt em rochas, podem ser resumidas da seguinte ma neira:

1. A reprodutibilidade de leituras em um esclerôme tro e entre esclerômetros (comparandomse com os resultados de outros autores), é muto boa. 
2. Discrepancias nas estimativas de resistência a compressão e abras̃a los Angeles são igualinente da ordem de $30 \%$.

3. Poderá constituir-se em excelente ensaio para medida do estaảo de alteração de rochas dada as suas caracteristicas de rapidez, facilidacie de execução, baixo custo, boa precisão e reprodutibilidade.

E) Recomendações

As seguintes xecomendações são sugeridas para comple tar este estudo:

1. rodas as anälises $€$ conciusões foram praticamente baseadas em resultados ảe ensaios de laboratorio. E essen cial que o valor deste Indice seja substanciado atravēs de maior quantidade de ensaios de laboratóric e de campo, em uma srance variedade de rochas.

2. Enquanto não for comprovado um sistema mais ade quado de medida, a aplicabijidade co aparelho é restringi áa.

3. Resultados de alyuns poucos ensaios, evidenciaran que as condições superficiajs (seca ou umida), tem uma in fluência significativa no resultado dos ensaios, como ocoxre nos ensains de compressão simples axial (seco e saturado). Deverão ser obtidos valores de inaices escierométricos para amostras secas e saturadas.

4. Estudo de correliçŏes do Indice esclerometrico . com o mödulo da elasticidade e coeficiente de poisson para rochas.

\section{F) Observações}

Alguns aspectos, importantes para uma padronização do ensaio, surgiram durante a execução destes ensaios e merecem registro, a saber:

1. Os ensaios deverão ser executados sempre perpendi cularmente à superfície de ensaio. 
2. O esclerómetro deve ser calibrado frequentemente, ou com o emprego da bigorna que pode acompanhar o instrumen to ou por comparação com um esclerômetro ajustado ou, com qualquer objeto de superficie dura, de valor esclerométrico previamente determinado.

3. A superficie de impacto do instrumento deverā ser previamente uniformizada (polimento com carborundum, p.ex:) e limpa.

4. O ponto de impacto deverá ser mantido pelo menos a $2 \mathrm{~cm}$ da extremidade do corpo de prova. As extremidades sempre fornecem leituras inferiores.

5. Nos ensaios em Iaboratório, deve-se usar sempre o mesmo suporte de apoio, caso não se disponha de corpos $\because$ de prova com espessuras maiores do que $8 \mathrm{~cm}$.

6. Os corpos de prova para ensaio em laboratorio de vem estar bem acabadas e sem trincas.

7. Ensaios em corpos de prova de uma determinada ro cha, devem sempre levar em conta a sua estrutura. im una rocha xistosa por exemplo, deverse efetuar ensaios paralela e perpendicularmente a esta feição.

8. Os corpos de prova devem ser convenientemente fi xados, paro evitar qualquer deslocamento durante o impacto.

9. O esclerometro schmidt para conareto possui uma energia de impacto elevada fraturando os corpos de prova de rochas. A energia de impacto do esclerômetro utilizado por Deere e Miller é de $0,075 \mathrm{kgm}$.

I.V.2 - Resistência ao impacto de coxpos de prova regulares

o ensaio de impacto descrito no método ASTM D3-18, constitui um ensaio físico bastante simples, desenvolvido para fornecer uma medida quantitativa do comportamento da rocha ao impacto. O valor obtido sera importante nos casos onde a rocha è submetida a impactos repentidos, seja como material solto, seja com ligantes. Os principais campos de aplicação constituem, poxtanto, a escolha de materiais ro - 
chosos para pavimentos de rodovias e pistas de aeroportos e lastros para vias férreas. Im concretos, o ensaio é restrito pois a aplicação da carga instantânea é puntiforme, fornecendo somente uma idëia qualitativa do ccmportamento de rochas.

A resistência ao impacto de rochas é influenciada primariamente, pelas suas características petrogräficas (9-36): mineralogia e textura. Em rochas igneas e metamórfi cas não xistosas, os grãos cristalinos estão em yeral, fọ temente interligados constituindo uma textura densa ocasionando elevadas resistências ao impacto.Por outro lado, em rochas sedimentares quartzosas, embora os grãos constituintes sejain muito duros (quartzo), a coesäc da rocha depende dasubstancia cimentante, que pode ser pouco resistente. um fator adicional, que infiuencia o comportamento mecânico de rochas crrtralinas face a essas solicitaçc̃es, é c tamanko cos grãos. O aumento desta granulação ocasiona a diminuif̧ão da superficie específica dos mesmos, enfraquecendo as ligações intergranulares, alēm de tornar as fraquezas estrutu rais intragranulares como microfraturamento, clivagem, planos de geminação, etc, bastante Linpoxtuantes.

Para a determinação ca resistência ao impacto de ro chas, existem ra literatura diversos procadimentos e equipa mentos, sendo os mais importantes, 0 ensaio de impacto Treton pelo método DER M26-52T, o mëtodo BS-812 e o método ASTM D3-18.

o ensaio de impacto em rochas pelo mëtodo ASTM D318, foi desenvolvido para medir a tenacidade a de rochas em corpos de prova cilindricos. Este mëtodo foi revisto en 1961 e continuou até hoje sem modificações. Cono se trata de um ensaio relativamente simples e de fácil execução, e como dispomos de poucos meios conhecidamerte precisos fara se medir caracteristicas tecnológicas de rochas, procuramos avaliar a aplicabilidade deste método para utilização rotineira. Para isto, foi desenvolvido nas oflcinas da seçäo de Mecânica do Instituto de Pesquisas Tecnológicas, o instru - 
mento de ensaio, conforme prescrito pelo método. o esquema do instrumento é apresentado no apênaice $B$.

com o equipamento construido, procurou-se estabele cer as caracteristicas das variāveis de ensaio: forma dos corpos de prova e procedimento. Posteriormente foram determinados a precisão dos ensaios, no de ensaios para 950 de confiabilidade e correlaçöes dos valores obtidos em diferen tes rochas, com diversas propriedades tecnológicas.

o procedimento experimental e os resultados atingi . dos, obedeceram a seguinte sequêrcia:

A) Estudo das variáveis de ensaio

Atravês de britagem, serragem e com o auxílio a a perfuratriz de laboratörio, foram preparados curpos de prova cubicos, cilindricos e irregulares de $2,5 \mathrm{~cm}$ de dimensão Iinear.

Para cada forma de corpo de prova após secagem em es tufa, foram executados 50 ensaios em uma unica rocha e com o mesmo procedimento, is to é, a cada queda de um peso padro nizado, acrescentou-se $1 \mathrm{~cm}$ na altura de queda ace ruetura do corpo de prova. Considerou-se a altura final como nedida da resistência ao impacto, em centimetros.

Os resultados encontrados apresentaram as seguintes. dispersões:

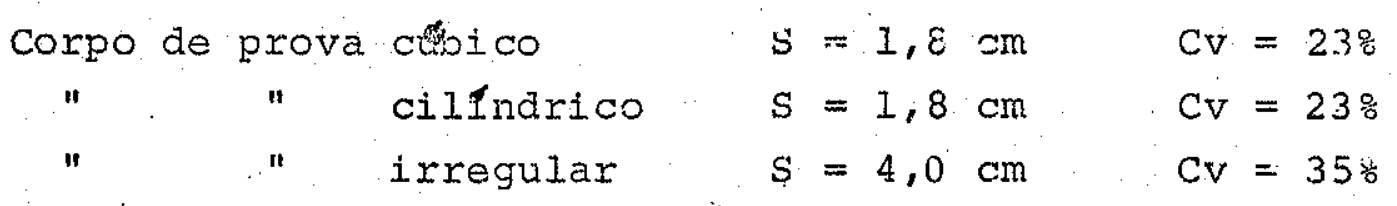

Alēm do.procedimento acima descrito, foram investiga dos 2 outros sistemas: o primeiro deles considerou o n? ce golpes necessärios para se romper o corpo de prova, caindo - peso le uma altura constante pre-tixada. os resultados pa ra 30 medidas nas alturas constantes de 5,7 e $10 \mathrm{~cm}$, deram coeficientes de variação da orden de 45 a $60 \%$. Para alturas maiores, a grande maioria das rochas ensaiadas rompeu-se com apenas 1 golpe e para alturas menores do que $5 \mathrm{~cm}$. procedimento obrigou a execução de um no exaustivo de 
saios para se romper o corpo de prova. O outro sistema de medida, consistiu numa modificação do sistema de altura fi nal, computando-se o resultaco como sendo, a soma das alturas de queda do peso até a ruptura do corpo de prova. Para este procedimento; o coeficiente de variação fol da ordem de $47 \%$

Fara a determinaçäo do exro relativo da média, foram ensaiados 30 corpos de prova de um basalto vesiculo amigdaloidal, que apresentou o maior valor äe dispersão, que foi de 0,3 , que corresponde a um coeficiente de variação de 22: e desvio padräo de 1,8 crin.

O 12 ? mirimo de ensaios, para se obter uma boa média representativa com $95 \%$ de confiança e erro relativo inferior a $15 \%$ no valor da mëdia, foi calculado a partir da dispersão total $\mathrm{S}=1,8 \mathrm{~cm}$, subtraindo-se a dispersão obtida em corpos de prova jsotrópicos (cálculos efetuados com as variâncias) - O resultaāo encontrado foi de 7 ensaios recessärios, para preencher estes requisitos de confiabilidada.

Conhecidas as variäveis de ensatos, procedeu-se à de terminação da Resistëncia ao impacto em corpos de prova cilindricos de diferentes rochás, cujos resultadics encon tram-se na tzbela

B) Anälise dos resultados

Os resultados obtidos foran analisacos pelo metodo de regressäo pelos mininos quajrados, para se determinar eventuais correlações com outras propriedales tecnolögicas. As equações de correlaçüo encontracias, considerandomse sem pre o valor da resustência ao impacto (código IC) como variävel independente, bem como os respectivos valores do coeficiente de correlação e erro paarão da estimativa ercontram-se na tabela 3 e nas figs. 4 e 5. Para a confeção dos grâficos de correlação escclheu-se a relaçăo linear pe la maion facilidade de interpretação e traçado, bem como pe la pequena diferença existente ros valores dos coeficientes de correlação.

Apesar do pequeno nümero de resultados, a análise de 
regressão revela que existem boas correlaçöes entre a resis tência ao impacto determinado por este nétodo e as propriedades tecnológicas. Ocorre uma correlação significante en tre a resistência ao impacto e os resultados de ensaios de impacto Treton, abrasão Los Angeles e compressão simples axid. As linhas de regressão obtidas para estes casos (fics 4 e 5), mostram que estão razoavelmente ajustadas aos pon tos obtidos.

C) Conclusões

As conclusões sobre a aplicabilidade do método podem ser resumidas da sequinte maneira:

1. O mëtodo AS'TM D3-18 apresentawse vago quanto ì confiabilidade para os 3 ensaios requeridos. o ne mínimo de ensalos requeridos para se ter una boa média representativa (para 95\% de confiança), com erro relativo inferior a $15 \%$ é de 7 .

2. A aplicabilidade do instrumento é limitada, com um coeficiente de variação da ordem de $22 \%$, sendo muito inferior ao do ensaio Treton (68).

3. Poderá constituix-se em ersaio expedito para esti mativa de cilgumas propriedades mecânj cas como resistència a compressão simples axial, abrasão Los Angeles e a pröpria resistência ao impacto Treton. As discrepancias nas estinativas destas propriedades são respectivamente da ordem de: $30 \%, 30 \%$ e $10 \%$.

4. Os resultados indicararn que os corpos de prova cí bicos, apesar da maior dificuldade na sua confeção, são tão adequados quanto os corpos de prova cilínaricos.

5. O procedimento de ensiio adotado pelo metodo AsTM D3-18 é o mais adequado, para este tipo de equiparion to.

D) Recomendações

Dado o pequeno numero de tipos litológicos ensaiados e os resultados promissores alcancados pelas correlasoses re 
comenda-se:

1. Execução de maior número de ensaios para uma maior variedade de rochas.

2. A determinação da resistência ao impacto poderá ser efetuada para os värios casos que a rocha apresentar. As sim sendo, poder-se-à determinar a resistência ao impacto perpendicular ao plano de xistosidade, paralelo a pilano de xistosidade (ou estratificação), seco, saturada, etc.

3. Poderá ser efetuado um estudo para aplicação des te ensaio na determinação do estado de alteração de rochas, tendo em vista que a resistência ao impacto è uma proprieda de bastante dependente das caracteristicas petrogrälicas e portanto deverä ser sensiveimente mutävel.

IV.3 - Resistência ao desgaste a úmico de rochas

Para um melhor aproveitamento de testemunhos de sondagens Franklin e outros (17) desenvolveram o aparelho de desgaste a ümido (figura e descrição no Apêndice B), que mede a velocidade de Exagmentação de uma rocha, çuando submetida a um ciclo padronizado de secagem e umedecimento. o procedimento consiste na colocação de 10 fragmentos de ro cha, cada um pusando 40-60 g, previamente secos em estufa e colocados em um tambor de ensaio o tambor é então imerso pela metade em um tanque com água e sirado lentamente pur 10 minutos. Os finos produzidos por este processc de desgas te passam através dos crivos da malha gue forma o corpo do tambor. O indice de desgaste a úmido é calculado como:

$$
R D U=\frac{\text { peso a seco da rocha retida no tambor }}{\text { peso a seco da rocha antes do ensaio }}
$$

Este Indice pode variar deste modo, de $0 \%$ quando a rocha se desintegra totalmente a 100 o de resistência quando não ocorre desintegração. Segundo os autores (17), os resuı tados dos ensaios seriam colocados em um perfil de sondagem e expressariam o comportanento da alteragão "in situ", con" 
sistindo portanto, en um ensaio de duxabilidade.

Tendo em vista, a.simplicidade do equipamento, a rapidez de execução do ensaio, sua alta reprodutibilidade (5\%) dentro do ensaio e a possibilidade de obter novos parâme tros mecânicos do estado de alteração, conseguimos a partir dos dados divulgados sobre o mesmo, desenvoiver um equipamn to semelhante nas oficinas da seçăo de Ensaios Mecânicos do Instituto de Pesquisas Tecnológicas.

Construído o equipamento, o próximo passo foi a de terminação das variāveis de ensaio, que possibilitaria elaboração de um método padronizado. As variāveis de ensaio investigadas foram: numero, peso e granulometria dos corpos de prova, precisão, tempo de ensaio e numero de cicios. pos texiormente, os resultados obtidos para diversas rochas fo ram submetido: a correlaçăo estatistica atraves da análise de regressão pelo mëtodo dos mínimos quadrados, com as vá rias propriedades temologicas determtnadas.

o procedimento adotado para determinação das variá veis de onsaio, que ainda se encontra em andamento, obede ceu a seguinte sequência: .

A) Estudo das variáveis de ensaio

Após britagem, lavagem e secagem em estuta, foram preparados corpos de prova de diferentes rochas, com pesos variando de 10 a $60 \mathrm{~g}$, que foram submetidos a ensaio, por um tempo fixo de 10 minutos de rotação, mantendo tambénl fi xo o numero de 10 fragmentos. Os rasultados obtidos mostraram que ocorra um aumento progressivo da perda até $30-35 \mathrm{~g}$ estabilizando á seguir por volta do peso de $60 \mathrm{~g}$.

Considerando-se o peso ideal dos fragmentos na fiara de $40-60 \mathrm{~g}$ e variando-se o tempo de ensaio de 5 a 70 minu tos, dentro do lambor, verificou-se que ocorre um aumento Iinear da peraa com o tempo.

Considerando-se 0 peso ideal dos fragmentos tanbëm na faixa recomendada por Franklin (18) de 40-60 g, o tempo de ensaio de 10 minutos, variou-se o no de fragmentos de 5 
a 20. Ocorreu uni aumento progressivo na perda com o aumento do ni de fragmentos ensajados até se estabilizar por volta dos 20 fragmentos.

Os resultados parciais para vários ciclos, isto é, ciclos alternados de rotação no tambor por 10 minutos subsequente secagem em estufa a $100-110^{\circ} \mathrm{C}$ por aproximadamen te 10 horas, demorstraram que pcorre um aumento progressivo da perda com o número de cíclos.

Para a ảeterminação da precisão dertro do ensaio fo ram efetuados 30 ensaios, consideranäo-se o tempo de $10 \mathrm{mi}$ nutos ce rotação e corpos de prova de 40-60 9 , como padroni zados. o srro paarào da média obtido fol de 0,1 para um desvio paarão de 0,6 e coeficiente de variação de 0,6\%.

Tendo em vista os resultacios ainda incompletos acer vadas variäveis deste ensaio, optou-se pelas recomenalações estabelecidas pelos autores deste equipamento, para determi nação da resistência ao desgaste a ümido de diversas rocias. Fara um melhor aproveitamento e conhecimento das limitações daste inatrumento, foi elaborado um plano de pesquisa $(E P C-7)$, cujo nëtodo de eisaio proposto, consta no Apênaice $B$ deste trabalho $(0$ procedimento adotado foi o de rranklin e cutros).

A anárise de regressão efetuada entre os valores de resistêrcia ao dasgaste a umido (da tabela 4 ) e as diver sas propriedades tecnológicas inaicaram que poderä haver uma correlação razoãve $\mathrm{I}$ cum a resistência a abrasão Los Angeles (figs, 5 e 6 ).

B) Conclusões

Embora os estudos estojam ainda em andamento, algu mas cunclusões prelininares pudem ser adiartadas:

1. o tempo desejāvel de rotação do instrumento duran te ensajo, não concorda com o tempo estabelecido pelos auto res (18): O tempo mínirno adequado deverá ser representado por um mäximo do desgaste, a partir do qual não deverá ocor rer modificações sensiveis na perda. 
2. As solicitaçöes imprimidas por este ensaio em rochas diferentes mostram que trata-se de um ensaio muito pou co sensivel.

3. Os resultados preliminares parecem indicar que fragmentos de 30 a $35 \mathrm{~g}$ são os que fornecem valores de re.sistência ao desgate com mator sensibilidade, dentro de um dado intervalo de tempo.

4. Embora Franklin tenha encontrado como adequado 10 fragmentos para ensaio, os resultados obtidos parecem indicar maior sensibilldade da aparelhagem com 15 fragmentos.

5. Estudos realizados no sentido de definir o nümero ideal de ciclos de ensaio, indicam a conveniência de se liti lizar vârios ciclos para aumentar sua sensibilidade.

6. O instrumento poderá ser aplicável para aistinçẽo de rochas de características tecnológicas pobres.

C) Recomendaçñes

1. Embora a precisão obtida tenha sido elevada, o instrumento não apresenta a sensibilidade desejáda. Possi .. velmente a intercalação de fases de alteração artificial neste ensaio, poderão ser de valia na investigação de sua aplicabilidade.

2. Devexão ser efetuados um mior volume de ensaios em uma maior variedade de rochas tanto para o dimensionamen to de amostras para ensaio, quanto para o estudc de coxrela ções estatísticas. 


\section{V. - ENSAIOS DE ALTERACÃO}

\section{V.I - Quadro experimental}

Os sistemas de observação puramente qualitativos " po dem fornecer uma impressão ütil do conjunto não permitindo entretanto, senão conclusões muito subjetivas sobre os "va lores apresentados pelas diversas rochas à ação de diferentes agentes. Existem na literatura diversos procedimentos experimentais para acelerar os processos de alteração : da natureza: imersão em etilenoglicol, saturação em ägua e se cagem em estufa, lixiviação continua com o extrator soxhlet, congelamento e degelo, altemancta de aguecimento e restria mento a seco, imersão em ägua oxigenada, alternância de saturaçăo em solução de sulfato de sōaio e secagem em estufa, etc. Entretanto, todos estes procedimentos apesar de consagrados, são utiljzados ra maioria dos casos sem o conteci mento de suas Iimitaçōes, seja quanto à simulação das condi ções atmosféricas; seja quanto à interpretação e aplicabili dade dos resultados. A aceitação de materiais ruchosos com base nos resultados obtidos com os ensaios citados, fica quase que exclusivamente na dependência de Ilmites empiri cos, variäveis conforme a resporsabilidade da obra.

Assim, rós procuramos estudar de um lado a comparaço entre diferentes processos de alteração aceleraca en labora törio com à alteração natural e por outro lado, o comportamento mecânico de diversas rochas face a essas diferentes solicitações fisicoquímicas, com a finalidade de escolher um mētodo mais adequado e de encontrar parâmetros numēricos que permitam prever o comportamento e estado de alteraça de rochas.

Os ensaios de alteração comparados foram: ensaio $\cdots$ de alteração por lixiviação contínua com o extrator Soxhlet, en saio de alteração por saturação em ägua e secagem em estu fa, ersaio de alteração por imersto em etilenoglicol e seca gem em estufa, ensaio de alteração por imersão em solução -

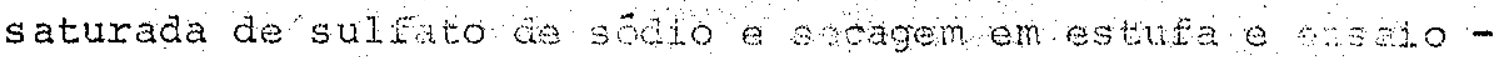
de alteração por exposição natural. 
Para a execução deste estudo, foram adotados dois ti pos de procedimentos de ensaio: o primeiro deles consistiu na execução destes ensaios de alteração em dez frações granulométricas diferentes de uma ünica rocha, em diversos ci clos de alteração; o segundo procedimento consistiu na execução destes ensaios de alteração para diversas rochas e me dida de seu comportamento mecânico a cada determinado numero de ciclos. Para este ültimo procedimento, o parâmetro me canico escolhido foi o ensaio de impacto Treton, tendo em vista que:

1. O valor de impacto Treton é bastante conhecido e muito usado em especificações principalmente para aprovação de agregados rochosos para pavimentação e concreto.

2. Trata-se de um ensaio de fácil execução, rápido, de alta reprodutibilidade (coeficiente de variação atē $6 \%$ ) ötima precisão (1\%).

3. Necessita de pequenas quantidades de amostras, $0-$ que permite realizar um grande nümero de ensaios.

4. Finalmente, a pouca disponibilidade de materiais para ensaio.

Dade as caracteristicas de elevada suscetiblinade às condị̂̃es de alteração, demonstrada por Nery, J.A.N. $\quad$ e Farjallat, J.E.S. (I5) e Farjallat, J.E.S. (14), escolheuse o basalto "C" da barragem de capivara (derrane II), para a comparação entre os processos de alteração acima citados e medida do comportamento mecânico.

\section{V.2 - Procedimentos para comparacão entre diferentes proces sos de alteracão}

Apös britagem, lavagem em água e secagem em estufa a 100-1.20 $\mathrm{C}$, as amostras de basalto tipo $\mathrm{C}$ da barragem de Capivara, foram peneiradas e separadas em dez fraçôs granulo métricas: $3^{\prime \prime}-21 / 2 ", 21 / 2 "-2 ", 2 "-11 / 2 ", 11 / 2 "-1 ", 1 "$ $3 / 4^{\prime \prime}, 3 / 4^{\prime \prime}-1 / 2^{\prime \prime}, 1 / 2 "-3 / 8^{\prime \prime}, 3 / 8^{\prime \prime}-$ No3, NO3 - NO4 e No4 - No8. A seguir, foram pesadas diferentes quantidades nas aiversas fraçoes, de tal forma que a superfỉ cie total 
dos fragmentos ("superficle especifica") oferecida aos processos de alteração seja a mais próxima possivel (tabela 5. $)$.

Conhecidas as quantidades de amostras necessärias nas diferentes fraçōes, os procedimentos adotados para os diferentes processos de alteração foram os seguintes:

A) Ensaios de alteração por lixiviação continua

Para o estudc da avaliação da alterabilidade de rochas por lixivi ação continua, foi utilizado um conjunto de extrá tores Soxhlet (descrição e fi qura no Apêndice B),

A alteração experimental de rochas em laboratörio, uti lizando extratores deste tipo foi descrita no trabalho de G.Pedro (32), que descreveu os aspectos mineralógicos e geoquimicos da alterargăo experimental, isto é, o comporta mento dinâmico dos elementos quimicos e neoformações de mi. rerais. O instrumento Soxhlet tenta simular no laboratório as condiçũes naturais de alteração, mas em velocidade muito maior, graças à temeperatura mais elevada (cerca de $70^{\circ} \mathrm{C}$ ) e velccidáde de percolação de ägua tambēm mu to maior. No "cli. ma" deste aparelic podemos distingutr duas regióes: zona otmosférica, oride as amostras ñ̃o estão submersas e onde a velocidade he percolaçâo da água è nuito grande, e zona de flutuação do nivel da āgua, onde as amostras se apresentam alternadamente imersas a emersas. Corresponderia segundo G.Pedro, a um clima tropical oceânicc exagerado.

Os ensaios para avaliação da alterabiljada ảe ro chas, submetidas ao processo de lixiviação continua, tive ram o seguinte procedimento:

Apōs cada 10 ciclos no extrator Soxhlet a partir de 20 ciclos, as amostras em diversas fracōes, foram soos en estufa a $100-110^{\circ} \mathrm{C}$ por aproximaramente 16 horas, estriadas à temperatura umbiente e peneiradas durante 5 minutos com as meamas peneiras nas quais tinham sido retidas antes do ensaio. A seguir, os materiais retidos foram pesados, computando-se as perdas en porcentagem em relação ao peso ini. cial. Este procedimento toi adotado até se completar 100 
ciclos no extrator (corresponaendo a 20 dias de ensaio), ob tendo-se as porcentagens de perdas acumuladas para os diver sos ciclos, nas diferentes fraçōes. Os resultados obtidos encontram-se relacionados na tabela 6 e colocados em grä ficos do tipo porcentagem de perda acumulada versus no de ciclos (fig. 7) e porcentagem de peráa acumulada versus superficie específica (fig. 8) ).

B) Ensaios de alteração por saturação em ägua e secá gem em estufa.

A ãgua pode ocasionar uma ação mecânica direta nos fe nômenos de alteração: o impacto das gotas de água da chuva e as äguas de rolamento são capazes de arrastar fragmentos de rochas. Mas, esta ação não é de nosso interesse pois im plica que as rochas estejam previamente desagregalas. Muito mais importante são suas ações indiretas ligadas às varia ções de tempexaturas e às alternâncias de saturą̧ão e seca gem.

- coeficiente de dilatação da água è muito superior ao das rochas, o que pode fazer com que as variações de tem peratura da água aprisionada nos poros possa provocar uina certa desagregação. Por outro iaão, as variações de umidade por si sö, sem c poder de separar os cristais pela trarstor mação da película de água jncergranular em goticulas, o que modifica as tensöes superficiais. Mas, o maximo de efeito destruidor sobre as rochas só é obtido pela combinação cos dois fatores: a variação de temperatura e umidade (P.Bírot. in (.Javey).

o estudo de avaliação da alterabilidade de rochas sob - efieito de alternâncias de ciclos de saturação e secagem foi efetuada da seguinte maneira:

Apös cada 7 ciclos de saturação em àgua durante 16 ho ras e secagem em estufa a $100-110^{\circ} \mathrm{C}$ por eproximadamenta 8 horas, a partir do 50 ciclo, as anostras en diversas fra. ções foram esfriadas a temperatura ambiente e peneiraas du rante 5 minutos com as mesmas peneiras nas quais tinham sido retidas antes do ensaio. A seguir, as amostras retidas foram pesadas, computando-se as perdas em om relaça a ao 
peso inicial. Este procedimento foi adotado até se comple tar 55 ciclos de saturação e secagem, obtendo-se as 8 . . de perda acumuladas para os diversos ciclos, nas diferentes fra ções. Os resultados obtidos encontram-se relacionados na ta bela 9 e colocados em gräficos do tipo o de perda acumu lada versus no de ciclos (fig. II) e o de perda acumulada versus superfície especifica (fig. 12).

c) Ensaios de alteração por imersão em etilenoglicol e secagem em estufa.

Sabemos que o etilenoglicol tem a propriedade de pro duzir uma expansão reticular de minerais argilosos do grupo das montmorillonitas e em algumas cloritas expansivas. De vido à sua alta polaridade e tensão superficial, acreditamos que este líguido provoque também, ao penetrar nas mi cro descontinuidades de rochas, contrações e expansões nas suas paredes.

Ensias de alteração de rochas com este If́quido foram atê hoje efetuados com a simples imersão de fragmentos de rochas na fração granulomētrica $1 "$ - 3/4", durante 15 dias. Decorrido es te tempo, as amostrás ensaiadas exam comparadas com amostras não ensaiadas da mesma rocha. Este é o procedi mento denominado "Olson test", adotado pela "U.S. Corps of Engineers" e seguido por diversos laboratöios de ensaios.

Para a avali ação da alterabilidade de rochas com imer são em etilenoglicol e secagem om estufa, escolheu-ce a priori, dois tempos diferentes de imersão: 1 hora e 6 horas. Após cada ciclo de imersão em etileroglizol. ( 1 e 6 ho ras), e secagem em estufa durante pelo menos 8 horas, as amostras nas diversas frações foram esfriadas à temperatura ambiente e peneiradas duxante 5 minutos com as mesmas penei ras nas quais tinham sido retidas antes do ensaio. A seguir, as amostras retidas foram pesadas, computando-se as perdas em $\frac{\text { a }}{\mathrm{em}}$ relação ao peso inicial. Este procedimento foi ado tado ate se completar para o caso de 1 hora de imersão, 18 ciclos e, para o caso de 6 horas de imersão, 11 ciclos, obtendo-ge as o de pexdas acumulades para os diversios ciclos, nas diferentes frações. Os resultados obtidos encontram nas tabelas $12((1)=1$ hora de imersão $)$ e $15((2)=6$ ho- 
ras de imersãol, e colocados em gráficos do tipo o de perda acumulada versus no de ciclos (figs. 15 e 19 ) e o de perda acumulada versus superficie especifica (figs. 16 e 20 ).

D) Ensaios de alteração por imersão em solução satura da de sulfato de sódio e secagem em estufa.

Os fenômenos de cristalização de sais e o crescimento de cristais, resultam de processos quase sempre físicos e por vezes químicos pois, é efetuada a partir de soluções. Segundo W. Correns (in C.Javey 26 ), podem ocorrer três casos possiveis:

a) Formaçăo de cristais hidratados. o exemplo tipico é a cristalização de gipso a partir da anidrita. Essa trans formação necessita 2 molëculas de àgua e provoca um aumento de volume importante, que desenvolve uma pressão de 1100 at mosferas.

b) Cristalização de um sal a partix de sua solução sa turada. As pressões que ela ocasiona são tais que șe fala em efeito explosivo de cristalização.

c) o crescimento de cristais pode desenvolver pres söes importantes mas é necessärio que a tensão superficial da solução permita que esta iltima penetre ras microdescontinuidades.

As alterações devidas à cristalização de sais são frequentes em ambientes desérticos, mediterrâneos e tropi cais ( 26). A resistência de rochas à desagregação por cristalização de sais, segundo G.Pedro (32) e M. Robert (37) é mais relacionada à sua estrutura petrográfica gue à sua composição química e é função de sua compacidade. As rochas porosas que possuem superficies externas rugosas, fazem com que os cristais se desenvolvam nos poros e pequenos vazios provo ando um estilhaçamento e uma desagregação superficial contínua. Uma rocha compacta apresentarâ superficies relati vamente lisas sobre os quais os cristais irão simplesmente se depositar.

Conforme G.Pedro (32), não ocorre sob a ạăo da cris- 
talização de sais, rupturas internas de um bloco rochoso em um certo numero de fragmentos de pequenas dimensões; o que acontece è uma ação superficial marcante, seja por uma regu larização das rugosidades superficiais, seja por descalça mento de minerais no caso de rochas granulares.

A determinação cos efeitos da cristalização de sais sobre uma rocha fol efetuada com o auxilio do método ASTM C 88:69 no qual, se provoca artificialmente a cristalização de sulfato de sódic. Apōs cada 2 ciclos de imersão em solução saturada àe sulfato de södio e secagem em estufa a 100$11.0^{\circ} \mathrm{C}$, a partir do 18 ciclo, as amostras nas diversas fra ções foram esfriadas à temperatura ambiente e peneiradas du rante 5 minutos com as mesmas peneiras nas quais tinham sido retidas antes do ensaio. A seguir, as amostras retidas foram pesalas, computando-se as perdas em em relação ao peso inicial, Este procedimerto foi adotado atë se comple tar 21 ciclos, obtendo-se as \& de pexdas acumulades para os diversos ciclos, nas diferentes frações. Os resultados obti dos, encontram-se relacionados na tabela 18 , e colocados em gráficos do tipo o de percia acumulada versus no de di clos (Eig. 23) e de peráa acumulada versus superfície es pecifica (fig. 24)

E) Ens zio de alteração por exposição natural

As ünicas referências existentes a respeito de en saios de alteração por exposição natural, com controle pe riödico, são as experiências de A. Demolon e E. Bastisse, efetuado em Versailies (ir M.Robert 37 ). Em 1930, estes autores instalaram $800 \mathrm{~kg}$ de granito, previamente britados; em caixas lisimétricas, expostas aos agentes atmosfëricos. As observações foram efetuadas no fim de 5,15 e 30 anos. o resultado apös 30 anos mostrou que a constituição física do granito foi profundamente modificada, para um materias pulverulento, enquanto que a alteraço quimica foi praticamento nu1a. Desta forma, em condições onde não age normalmente ne nhum fator físico (gelo ou calor), mas simplesmente fatores climäticos, que em geral produzem uma evolução tipicamente 
qứmica, obteve-se um efeito considerăvel de desagregação.

Usualmente, em estudos de alteração de rochas por exposição natural, nos locais de obras, os materiais rochosos de interesse para aproveitamento são simplesmente expostos às Intempéries sob a forma de brita, observando-se o compor tamento durante intervalos de tempo determinado, ou execu tando-se ensaios de peneiramento para a obtenção da curva granulométrica após ensaio. A \% de perda determinada ou pe neiras empiricamente estabelecidos e a observação visual, constituem os critērios de aprovação de materiais quanto à al terabiliaade.

Neste trabalho, apresentamos um novo procedimento pa ra se determinar a alterabilidade de rochas face à exposi ção natural. Os ensaios de alteração por exposição natural foram executados pelo geólogo J.A.N. de Oliveira, na barragem de Capivara, em basaltos dos tipos A, B e C. O procedimento adotado para o basalto $C$, pode ser resumido da seguinte for ma: amostras de rochas britadas e peneiradas na fração I 1/2" - 1", foram submetidas à alteração natural durante um ano. Para cada mes de exposição, eram computadas as porcentagens desagregadas nas peneiras nas quais tinham sido reti das antes do ensaio. Obteve-se assim, as o de perdas acumuladas para os diversos tempos de exposição. Os resultados obtidos foram relacionados na tabela 21 e colocados em grá ficos do tipo \% de perda acumulada versus tempo de exposi ção em meses ou dias (fig. 27 ).

V.3 - Medida do comportamento mecãnico

- controle do comportanento mecânico face às diferentes solicitações impostas pelos ensaios de alteração, foi efetuado utilizando-se o ensajo de impacto treton (nétodo IPT M-52) como parâmetro mecânico, para 18 rochas de procedências e naturezas litológicas diferentes.

o ensaio de impacto Treton consiste em se submeter 20 fragmentos de rocha entre as dimensões de $3 / 4 "$ e $5 / 8 "$, lava dos e secos, em estufa a $100-110^{\circ} \mathrm{C}$ por 24 horas, a 10 impac tos de um peso de $15,88 \mathrm{~kg}$ caindo em queda livre de uma altura de $38,4 \mathrm{~cm}$, no aparelho Ireton. Após ensaio, o mate - 
rial deve ser lavado na peneira no 12 (abertura de $1,68 \mathrm{~mm}$ ), atê que as superficies estejan livres de pó. o material é então, levado à estufa a $100-110^{\circ} \mathrm{C}$ por 24 horas, resfriado e pesado. Para cada rocha a ser ensaiada devem ser efetua das 3 determinações. O valor de impacto Treton é a relação percentual entre as diferenças de peso inicial e final pelo peso inicial, sendo que é considerada a média de 3 resultados. A relação entre o peso final, retido na peneira no 12 e o peso inicial, expresso em ó é a resistência ao impacto Treton do material (que constitui uma outra forma de expres sar o resultado do ensaio e representa o complemento da for ma anterior, para 100\%). Os valores da resistência ao impac to Treton das 18 rochas estudadas, antes dos ensaios de alteraçăo, encontram-se na tabela 23 .

- procedimento adotado para todos os ensaios de alteração efetuados, com excessão do ensaio de alteração por ex posição natural, foi o seguinte:

Apōs britagem, as amostras foram lavadas e secas na estufa a $100-110^{\circ} \mathrm{C}$ e peneiradas, após resfriamento, na peneira do ensato Treton. Do material separado, foram tomadas tantas amostras quantos foram os ensaios mecânicos intermediários efetuados, para um determinado nümero de ciclos. De corrido o intervalo de ciclos pré-estabelecido, uma das amostras de cada rocha foi retirada para medida da resistên cia mecânica, continuando as demais amostras até o próximo nümero de ciclos requerido. A amostra retirada deve ser la vada e seca a $100-110^{\circ} \mathrm{C}$ e peneirada durante 5 minutos com a mesma peneira na qual tinha sido retida antes do ensaio. A seguir, fol pesado o material retido de cada fração, consti tuindo o material passante nas peneiras, a perda em peso de vido ao ensaio de alteração, correspondendo à parte mais desagregāvel, de resistência mecânica nula. o material reti do, pesado, foi levado para o ensaio de impacto Treton, pelo mëtodo IPT M-52, correspondendo o valor obtido à resistên cia mecanica do material que resistiu ao ensaio de altera ção.

Os fragmentos de basaltos dos tipos A, B e C, submeti 
dos à exposição natural durante quase um ano, na barragem de Capivara, na granulação de $11 / 2$ - 1 ", foram britados pa ra a granulação do ensaio Treton, lavados e secos em estufa a $100-110^{\circ} \mathrm{C}$ e ensaiados pelo método IPT M-52, corresponden do o valor obtido à resistência mecânica do material que re sistiu ao ensalo de alteração. A de perda do ensaio de al teração, de resistência nula, foi obtida inicialmente, atra vës dos ensaios de exposição natural, descrito no Item ante rior.

- cálculo da resistêncla mecânica final do material, para um determinado nümero de ciclos ou tempo de ensaio, ë efetuado ponderando-se as resistências mecânicas dos materiais passante e retido apōs o ensaio, através da expressão:

$$
R f=\frac{x \cdot R p+(100-X) R r}{100}
$$

onde:

$x=\frac{\circ}{\partial}$ de perda no erisaio de alteração

$100-\mathrm{X}=\mathrm{\%}$ de material que resistiu à alteração

$\mathrm{Rp}=$ resistência mecânica do material passante

$\mathrm{Rr}=$ resistência mecânica do material retido

Rf = resistência mecânica final para um determinado nu mero de ciclos ou tempo de ensaic de alteração.

Como $R p=0$ (material desagregado), a expressão acima fica reduzida $a$ :

$$
\operatorname{Rf}=\frac{(100-X) \operatorname{Rr}}{100}
$$

Os resultados obticios da resistência mecânica finai, apös os diferentes ensaios de alteração, para as 18 rochas estudadas, encontram-se na tabela 23 . Com excessão de a guns cásos, somente para os basaltos foram efetuadas 2 a 3 medidas intermediárias de resistência, nc decorrer dos en saios. Os valores obtidos encontram-se ralácionados . na tabela 24 , sob a forma de o de perda, tanto para os en saios mecânicos, como para os ensaios de alteração e, em gräficos do tipo o de perda versus no de ciclos (figs. 30 
a $57,1$.

calculados os valores da resistência mecânica final, é possivel deterninarmos a queda porcentual de resistência, em relação à resistência mecânica injicial, dos diversos mam teriais, submetidos às diferentes condiçôes de alteração, atravēs da seguinte expressão, que é vālida para o intervaLo de ciclos ou tempo de ensajo considerado:

$$
\Delta R=\frac{R I-R I}{R i} \quad 100
$$

onde:

$$
\begin{aligned}
\Delta R & =\text { queda fercentual da resistência mecânica } \\
\mathrm{RL} & =\text { resistência mecânica inicial } \\
\mathrm{Rf} & =\text { resistência mecânica final, para un determinado } \\
& \text { no de ciclos ou tempo de ensaì. }
\end{aligned}
$$

A relação entre a queda percentual de resistencia me cânica e a resistência mecânica inicial, fornece um indice que pode exprimix a suscetibilidade de uma dada rocha em sofrer uma queda ra sua resistência quando submetida a en saios de alteração. Este Indice, proposto neste trabalho. foi denominado de cueficiente de alterabilidade especifica $K$ conce $K=\frac{\Delta R}{R i}$, cujo valor mínimo ë diference de zero e valor máximo igual a unidade. Isto significa que quanto mais próximo da unidade, maior seră a alterabilidade da rocha.

Os valores dos cueficiontes de alterabilidade especifira calcuiados para as 18 rochas estudadas, nos diterentes ensaios de alteração, encontram-se na tabela 25 , com excessão dos ensaios de exposiçäo natural, onde temos somente os valores para os basaltos de capivara.

Observa-se que para a madida e comparação do comporta mento mecâmico durante alteracão foram considerados os se guintes intervalos de ensaios: ensaio de alteração via Soxh let (30 ciclos), ensaio de alteraçâo por saturaçãomsecagem (30 ciclos), ensaio de alteração com etilenoglicol (15 dias de imersão), ensaio de alteração com sulfato de södio (15 cíclos) a ensalo de aleração por exposiçäo natural (6 me - 
ses) : O ensaio de alteração com o etilenoglicol, para diver $s$ as rochas, foi efetuado com a imersão de amostras durante 15 dias e posterior secagem em estufa, em vez do procedimer to adotado no item V.2.C., para que houvesse apenas a in fluêncla deste reagente. 


\section{TERAÇÃO}

Neste capitulo, os resultados experimentais dos ensaios de alteração são examinados estatisticamente, fornecendo as correla ções dentro dos ensaios efetuados e com novos parâmetros introdu zidos.

\section{VI.I - Comparação entre os diferentes processos de altera- ç̃̃o.}

Os resultados dos ensaios por diferentes processos de alteração, efetuados em diverșas granulometrias do basal to tipo C da barrragem de Capivara, evidenciaram um comportamento bastarite similar em todos os casos, como se pode verificar nas curvas obtiäas relacionando a 8 de perda acumulada e o no de ciclos ou tempo de ensaio. Vejamos separadamente cada prosesso de alteração:

A) Ensaio de alteração com o extrator Scxhlet

As linhas identificadas de A a i da fig. 7 , repre sentam curvas de alterabilidade nas diferentes granulome trias ensaiadas, respectivamente de $3 "-21 / 2$ " a No 4 No 8, conforme a tabela $6^{\circ}$. Verifica-se em todas as cur vas que ocorre uma perda acentuada ros prineiros ciclos, pa ra em seguida estabilizarem aproximando-se assintóica e quase paralelamente em direção à Lesagregação total. Se con siderarmos este comportamento em termos de velocidade de alteração, que seria a relação entre a o de perảa e o inta valo de ciclos ou tempo considerado, podemos dizer que a ve locidade decresce com o tempo e a função entre estas variāveis è do tipó não linear.

Do mesmo modo, relacionando-se a.superfície especifi ca dos fragmentos com a o de perda acumulada, verifica - se que a função entre estas variāveis é do tipo não linear (fig. 8 ). A \% de perda acumulada aumenta com a diminuição da granulometria, para um mesmo no de ciclos ou tempo de ensaio. As linhas identificadas de $\mathrm{C}_{20}$ a $\mathrm{C}_{100}$, representam curvas de perda no ensaio de alteraçãc, respectivamente 
para 20 a 100 ciclos. Este gräfico demonstra portanto, a in fluência do tamanho dos fragmentos no ensaio de alteração, principalmente em fragmentos maiores do que 1 1/2", dimi nuincio em torno da fração 3/4" - 1/2" em direção às granula a ções menores.

As tabelas 7 e 8 apresentam os resultadcs da anälise de regressão pelo mëtodo dos minimos cyuadrados, res pectivamente das relações: $\%$ de perda acumulada versus no de ciclos e o de perda acumulada versus superficie especifi ca. Foram obtidas as equações e coeficientes de correlaçäo para as funções exponencial e potencial, verificando-se que em todos os casos, a melhor correlação é obtida em funções do tipo potencial, que podem ser expressas genericamente por:

$$
\begin{aligned}
& \mathrm{Pi}=a i \mathrm{Ci}^{\mathrm{ki}} \\
& \mathrm{Ci}=\mathrm{bi} \mathrm{s}^{\mathrm{mi}}
\end{aligned}
$$

onde:

$$
\begin{aligned}
\mathrm{P} i= & \text { o de perda acumulada para urn determinado no ae } \\
& \text { ciclcs } \\
\mathrm{C} i= & \mathrm{n} \text { o de ciclos considerado } \\
\mathrm{Si}= & \text { superficie especifica de uma aada fração } \\
\text { ai, bi }= & \text { constantes para cada equação dás curvas de alte } \\
& \text { ração. } \\
\mathrm{ki}, \mathrm{mi}= & \text { coeficientes angulares das tangentes às curvas } \\
& \text { de alteração em cada ponto. }
\end{aligned}
$$

Representando-se us funções potenciais num gräfico bilogarítmico, obtemos as linhas teöricas para as relações acima citacas(figs. 9 e 10 ). Para a relação entre perda acumulada e o no de ciclos, verifica-se que ocorre uma nitida convergência de alterailidade de todas as fra ções, sendo que a alteração é maior nos diclos iniciais pa ra as frações menores do que $2^{\prime \prime}-11 / 2^{\prime \prime}$ (P3), diminuindo no decorrer do no de ciclos ou tempo de ensaio de alteração. Nas frações maiores do que 1 1/2", a alteração se processa muito mais lentamente nos ciclos iniciais, devendo prosse - 
guir atē a desagregação total. A queda na inclinação das li nhas de alterabilidade das frações maiores para as frações menores, demonstra que i alteração se processa rapidamente nas granulações inferioxes a 1 1/2" ao passo que, nas fra ções maiores é mais lenta, se desenvolvendo continuamente até a desagreqação total, se o processo. não for interrompido. O fato de liuha P10 (fração No 4 - No 8), estar situada entre as Iinhas P7 (fração 1/2" - 3/8") e P8 (fração 3/8" No 3), pode indicar que estamos pröximo à granulação final da alteração ou seja, a granulação para a qual tendem as de mais frações, no processo de des żregação.

- gráfico da relação entre o de perda acumulada e a superficie especifica dos fragmentos $y$ mostra nitidamente que quanto maior a qranulação, mais lentamente se processará a sua alteração (isto ë, serão recessários mais ciclos de ensaio para se atingir a mesma o de perdal, e que a medi da que aumentamos o tempo de ensaio, diminui a influência do efeito de escala. Esta infiuêricia pode ser avaliada tomando-se por exemplo, a linha $\mathrm{C}_{2} \rho^{\prime}$ onde pawa um fragmento de superficle especifica $0,1 \mathrm{~cm}^{2} 1$, temos $1,5 \%$ de perua e para um fragmento de superifice especifica $10 \mathrm{~cm}^{-1}$, temos .. 605 de perda, para o mesmo tempo de ensaio, ou seja, 20 ciclos.

B) Ensaio de alteração por saturação-secagem

As linhas identificadas de $A$ a $J$ da fig. 11 , representam curvas de a] terabilidade nas diferentes granulome trias ensaiadas, respectivamente de $3 "$ - $21 / 2 "$ a Nod - No 8, conforme a tabela 9 .

Obsarva-se em todas as curvas, que ocorre uma perda bastante rāpida nos primeiros 20 ciclos, para em seguida se tornarem quase constantes, aproximando-se assintótica e quase paralelamente em direção à desagregação total. Assin, a velocidade de alteração decresce com o tempo e a função que exprime a dependência entre estas variäveis ë tambëm do tipo não Iinear, como no ensaio anterior.

A fig. 12 apresenta vărias curvas que relacionam a 
o de perda acumulada e a superficie especifica, corresponden tes aos diversos ciclos de ensaio de alteração por satura ̧ão-secagem. As linhas identificadas de $\mathrm{C5}$ a $\mathrm{C} 48$, representam curvas de perda no ensaio, respectivamente de 5 a $48 \mathrm{ci}$ clos. Do mesmo modo, estas curvas mustram que a relação en tre estas variāveis é do tipo não linear, e a influência da granulometria no ensaio, diminui em torno da fração 3/4" $1 / 2$ " para grãos inferiores.

As equações de regressão obtidas, relacionando-se a \% de perda acumilada e o no de ciclos, e a 8 de perda acumu lada e a superficie especifica dos fragmentos, encontram-se respectivamente nas tabelas 10 e 11 . Os coeficientes de correlação para ambos os casos, demonstram que a melhor cor relação é representada pelas funções do tipo potencial, cuja expressão geral e a mesma da descrita no item anterior.

As linhas teöricas das relações acima, encontram-se nas figs. 13 e 14 . Para a relação entre $\%$ de perda zcu mulada e o no de ciclos, verifica-se tambëm que ocorre uma nítida convergência de alterabilidade de todas as frações. Do mesmo modo que no ensato de alteração via soxhlet, queda na inclinação das linhas de alterabilidade, das ere ções maiores para as menores, mostra que a alteraça se pro cessa rapidamente nas granulações inferiores a 1 1/2", ao passo que nas frações maiores é majs lenta se desenvolvendo continuamente até a desagregaçäo total, caso o processo não seja interrompido.

Para a relação entre o de perda coumulada e a superficie especifica dos fragmentos, observamos que a influên cia do efeito de escala torna-se praticamente semeihante a partir do 4 : ciclo, diminuindo sensivelmente. Este fato é demonstrado pela aglomeração das curvas $\mathrm{C4}, \mathrm{C5}, \mathrm{C6}$ e $\mathrm{C7}$ e pela queda na inclinação das curvas.

C) Ensaio de alteração com etilenoglicol

As linhas identificadas de $\mathbb{F}_{2}$ a J das figs. $15 \mathrm{e} 19$, representam curvas de alterabilidade nas diferentes granulo metrias ensaiadas, respectivamente de $3^{n-2} 1 / 2^{\prime \prime}$ a $N A=$ 
No 8 , conforme as tabelas 12 e 15 - o tempo de imersão no etilenoglicol, afetou consideravelmente o comportamento du rante o ensaio pois, no caso (1), imersão de 1 hora, foram

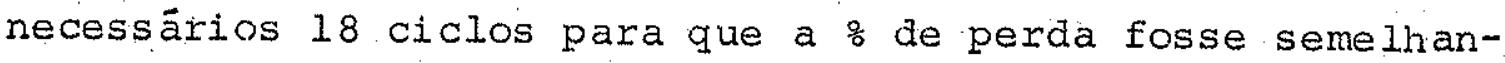
te ao caso (2), imersão de. 6 horas, onde foram necessärios apenas 12 ciclos, para uma desagregação quase total. Entretanto, devido ao major no de fases de aquecimento e resfria mento para o caso da imersão de 1 hora, a perda ros primeiros ciclos é mais räpida que no caso da imersão de 6 horas. No primeiro caso, até a estabilização das curvas são necessärios apenas 3 a 7 ciclos enquanto que, para o segundo ca so, são necessärios 3 a 10 ciclos.

Apesar destas diferenças iniciais, a configuração das curvas em ambos os casos é a mesma, mostrando que a ve locidade de alteração decresce com o tempo e a função que exprime a dependência entre estas variāveis è tambārn do ti po não linear, como nos processos de alteraçăo vistos anteriormente.

As figs. 16 e 20 , apresentam diversas curvas que relacionam a o de perda acumulada e a superficie específica, correspondentes aos diversos ciclos de alteração por satura ção em etilenoglicol e secagem em estufa. As linhas laentificadas de $C_{1}$ a $C_{18}$ ( 1 hora de imersão) e $C_{1}$ a $C_{11}$ (6 horas de imersão), representam curvas de perda no ensaio, respectivamente de 1 a 18 ciclos e de 1 a 11 ciclos. O fato áa configuração das curvas no caso da imersão de 1 nora, se apresentax muito mais irregular do que no caso da imersão de 6 horas, pode ser interpretada como uma saturação incompleta no priméiro caso, que depende da maior ou menor facilidade de acesso do etilenoglicol nas microdescontinuidades; - que só poderia ser efetuada por uma saturação mais comple ta. Em anbos os casos, entretanto, a relação entre estas va riāveis é do tipo não linear, e a influência da granulome tria no ensaio diminui em torno da frargão $I^{\prime \prime}-3 / 4 "$ em dire ção às frações menores.

As equações de regressão obtidas, relacionando-se a 
\& de perda acumulada com o no de clclos ey a o de perda acu mulada com a superfície específica dos fragmentos, encontran -se respectivamente nas tabelas 13,16 e $14,17$. Os coeficientes de correlação encontrados para estas rela ... ções, demonstram que a melhọ correlação é representada pe las funções do tipo potencial, cuja expressão geral è a inệ ma da que se encontra no item A. Além disso, invariavelmente este coeficiente é mais elevado para o caso da imersão durante 6 horas, demonstrando que as curvas das relações en contradas são melhor ajustadas aos valores obtidos. As 1 i nhas teóricas destas correlaçōes encontram-se nas figs. 17 , 21 e 18,22 . Para a relação entre o de peráa acumula da e o no de ciclos, verifica-se em ambos os procedimentos, uma ótima convergência na alterabilidade de todas as fra. ções sendo entretanto, melhor para o caso da imersão durante 6 horas. A diminuição da declividade das curvas de aj.terabilidade das frações maiores para as menores, demonstra que decorridos os ciclos iniclais, onde a alterabilidade é maior nas frações menores, ocorre uma diminuição das veloci dades de alteração para os ciclos subsequentes, com a diminuição do tamanho dos frágmentos.

Para a relação entre o de perda acumulada e a superficie especifica dos fragmentos, as curvas teóricas evidenciam que a influência do efeito de escala se torna semelhan te e diminui, para o caso de 1 hora de imersão a partir do 88 ciclo e, para o caso de 6 horas de imersão, a partir dc 68 ciclo. Este fato è demonstrado pela aglomeração e queda na inclinação das linhas, em ambos os casos.

D) Ensaio dè alteração com sulfato de sốcio

As iinhas identificadas de A a J da fig. 23 , re presentam curvas de alterabilidade nas granulometrias en saiadas, respectivamente de $3 "-21 / 2 "$ a No $4-$ No 8 , con forme a tabela 18 . Observa-se em todas as curvas, que ocorre uma perda bastante rápida nos primairos 7 ciclos, pa ra em seguida se tornarem quase constantes aproximando-se assintótica e quase paralelamente, en direção à desagrega ção total, e a velocidade de alteraça decresce com o tempo 
atravēs de uma função do tipo não linear.

A fig. 24 apresenta diversas curvas que relacionam a $\frac{0}{b}$ de perda acumulada e a superficie especifica dos frag mentos, correspondentes aos ciclos de ensaio de alteração por saturação em solução de.sulfato de sōdio e secagem em estufa. As linhas identificadas de $C_{1}$ a $C_{17}$, são as curvas de perda no ensaio, respectivamente de 1 a 17 ciclos. Verifica-se tambëm que a relação entre estas variáveis é do ti po não linear e a influência das dimensões dos fragmentos diminui a partir da peneira 1 1/2" - 1 ", em diréção às granulaçōes inferiores. Apesar de seguir a mesina tendência das demais curvas, a irregularidade da curva $c, \vec{e}$ explicada $p e$ la heterogeneidade das amostras ensaiadas pois, cada ponto indicado na mesma, representa amostras diferentes da mesma rocha.

As equações de regressão obtidas, relacionaildo-se as variăveis acima, encontram-se nas tabelas 19 e 20 . os coeficientes de correlação para ambos os casos, demonstram que a melhor correlação e representada pelas funções do po potencial, cuja expressão seral é a mesma dos ensatos ar, teriores. As linhas teoricas obtidas a partir destas equações encontram-se nas figs. $25^{\circ}$ e 26 . Com excessão de algumas diferenças na ordem de distribuição das linhas de alterablitidade, o comportamento tocal é semelhante ao dos ensaios anteriores, para ambas as correlaçóes. A queda mais acentuada na inclinação das linhas de alteração se processa a partir da fração 1" - 3/4" em direção às grarulações infe riores e o efeito de escala torna-se praticamente semelhante a partir dó 6\% ciclo, diminuindo em secuida. As divergên cias observadas em algumas destas Iinhas são devidas essencialmente à heterogeneidade das amostras ensaiadas.

E) Ensajo de alteração por exposição natural

Os ensaios de alteração por exposição natural, efe tuados em uma única fração (1 1/2" - 1"), no basalto tipo c da barragem de Capivara, evidenciaram nitidamente dois comportamentos (mëdia de 6 amostras cada uma), como se pode ve 
rificar na tabela 21 . As linhas identificadás como $D_{1} e$ $\mathrm{D}_{2}$ da fig. 27 , representam as curvas de alterabilidade obtidas. A curva $D_{I}$. representa a curva da rocha mais altera da. Em ambas as curvas, observa-se que ocorre uma perda bas tante räpida nos primeiros 2 a 4 meses de exposição, para em seguida se estabilizarem tornando-se quase constantes mas, aproximando-se assintótica e quase paralelamente em di reção à desagregação total, sendo que a velocidade de alteração decresce com o tempo através de uma função do tipo não linear.

A anälise de regressão pelo método dos mínimos qua drados, para as variāveis, of de perda acumulada e tempo de exposição, demonstrou que a melhor correlação é representada pelas funções do tipo potencial, que pode ser expressa da mesma forma genërica dos ensaios anteriores. As equações obtidas encontram-se na tabela 22 , e as Iinhas teoricas obtidas a partir das mesmas, na fig. 28 . As Iirhas $P_{1}$ e $\mathrm{P}_{2}$ deste gräfico, representam o comportamento das 2 amos tras diferentes de uma mesma rocha $\left(D_{1}\right.$ e $\left.D_{2}\right)$. Também neste caso, ocorre uma converôência ne alterabilidade das duas amostras em diferentes estados de alteração, com o tempo. Isto è devido ao aumento da velocidade de alteração com o tempo de exposição, da amostra $D_{2}$ em relação à amostra $D_{1}$ (apesar de ambas as velocidades decrescerem no decorrer do ensaio). A amostra $D_{1}$ estaria mais próxima do equilíbrio com as condições naturais possuindo portanto, menor velocidade de alteração.

F) Comparação entre os resultados

Obtidas as Linhas teóricas de regressão das relações entre 8 de pexda acumulada e o no de ciclos ou tempo de en saio, foi conscruido o gráfico da fig. 29 , que permite a comparação entre os resultados de diferentes procedimentosde ensaio de alteração. como o ensaio de altexação por expo sição natural foi efetuado em uma ünica granulação, e como a alteração decende da granulometria considerada, para um determinado intervalo de tempo (efeito de escala), tomanos 
os resultados da mesma fração em cada processo de alteraçäo (fração $11 / 2^{\prime \prime}-I^{\prime \prime}$ ), para tornar possivej a comparação. Além đisso, como para os ensaios de alteração por satura ção-secagem, por imersão em etilenoglicol e com o emprego da solução saturada de sulfato de sódio, cada ciclo tem apro ximadamente 1 dia de duração, foi feita a equivaiência: 1 dia $=1$ ciclo. Para o ensaio de lixiviação continua com o extrator Soxhlet, a eguivalência efetuada foi de: I dia = 5 ciclos, pois este jirstrumento efetua 5 ciclos de lixiviaç̃o por dia. Desta forma, cada ciclo neste grâfico, repre senta tamoen um dia de ensaio por exposição natural.

Considerando-se a mesma de perda acumulada para to dos os provessos de alteração, por exemplo 50\%, verifica-se que são necessários aproximauamente 2 ciclos de saturação em solução de sulfato de súdio, 3 ciclos de 6 horas de imer são em etilenoglicol, 4 ciclos de saturação em ägua, 4 a 5 ciclos de 1 hora de imersão em etilenoglicol, 10 ciclos de lixiviação no extrator soxhlet e, 320 dias ou ciclos de aterậo pox exposiçăo natural, paxa o caso do basalto C da Iinha $\mathrm{P}_{2}$, gue é o que foi ensaiado em todos cs procedi mentos, para se atingir a mesma o de perda acumulada cita da. Portarto, o ensaio de alteração com a soiução de sulfato de sódio apresentou-se como o processo miais eficaz de desagregação para esta rocha. o major paralelismo entre as linhas de alteração via soxhlet e lo ensaio de alteração por exrosição natural, polería ser uma inaicação do grau de simulação das condições naturais imprimidas pelo processo de lixiviação continua, o que constituiria em mais un argumento a favor de G.Pedro (32). Entretanto, a comprovação deste fato está na dependência da execução destes mesmos en saios em diferentes rochas.

Derivando-se a equação yeral, válida para todos os processos de alteração, obtem-se teoricamente as velorida des imprimidas pelos mesmos:

$$
\mathrm{Pi}=\mathrm{ai} \mathrm{Ci}^{\mathrm{ki}}
$$


$\frac{d P}{d C}=a i k i \cdot(C i)^{k i-1} \quad$ (equação geral da velocidade de altera ção).

Os resultados obtidos relacionando-se as velocidades de alteração com o tempo ou no de ciclos, encontram-se na fig. 58. Neste gráfico, observa-se nitidamente que a velocidade de alteração em todos os processos, diminui com - tempo eque, excetuando-se o caso do ensaio con etileno glicol ( I), de validade limitada, a maior velocidade é imprimia pelo ensaio com a solução saturada de sulfato de sô dio.

VI.2 - Comportamento mecânico nos diferentes processos de alteração

Os gräficos das figs. 30 a 57 ilustram o compor tamento mecânico de todos os basaltos estudados, submetidos aos diferentes processos de alteração. De um modo geral., ocorreu uma maior ou menor queda de resistência mecânica, .. (amento da de perda), decorridos um deterninado no de ciclos, em todos os processos. O aparente eumento da resistência mecânica registrado em alguns casos, se deve única e exclusivamento à heterogeneidade da própria rocha pois, cada ponto de medida, corresponde a amostras diferentes de uma mesma rocha. Vejamos separadamente o comportamento de cada basalto estudado:

O basalto "A" da barragem de Capivara não sofreu modificações no ensaio de lixivi ação conínua mas, foì sensivelmente afetado pelos demais processos, sendo o mais efi caz a alteração por ciclos de imersão em solução de sulfato de södio e secagem em estufa.

Os basaltos "B" $e$ "C" de Capivara foram quase que to talmente desagregados em todos os processos de alteração com excessão do ersaio por lixivi ação continua. Este fato se deve a presença nestas rochas, de feições potencialmente favoräveis ao progresso da alteração (vesilculas, amígalas. minerais argilosos expansivos), identificadas na anälise pe 
trogräica.

o basalto de Salto osório se mostrou extremamente : suscetível à alteração com sulfató de sódio e, praticamente não foi afetada pelos demais ensiaios. A sua desagregação se processou por Ixagmentação, evidenciando uma abertura Eorça da de suas vesículas e amigdalas bem como de eventuais mi crodescontinuidades, pela cristalização deste sal.

o basalto de olimpia passou quase incólume pelos pro cessos de alteração por lixiviação contínua, etilenoglicol e saturação-secagen, sencio sensivelmerte afetada pela alteração com sulfato de sódio. Como se trata de uma rocha ex tremamente compacta, este fato poderia ser explicado por uma menor capacidade em resistix às variações termométricas, fazendu com que as alternâncias de dilatações e contrações originem pequenas descontinuidades, favorecencio a percola ção e cuistalização da solução salina.

o basalto da serra de Brotas comportou-ge satisfatoriamente nos ensaios ds alteração por lixiviação continua e sulfato de södio, sendo medianamente afetaöo pelos ensaios de saturação-secagem e etilenoglicol. A presença de uma quain tidade razoävel de vidro $(\sim 30 \%)$ e de argilas expansivas poderia explicar este comportamento.

o basalto da I Iha Solteira resistiu razoavelmerte bem a todos os processos de alteracão a que foi submetido, com excessão do ensaio com suifato de sōdio, onde foi media namente afetado. A mesma interpretação emitida para o basa to de Olimpia deverá ser aplicável para este caso.

obtidos os valores das resistências ao impacto Tre ton final das diversas rochas, submetidas aos diferentes processos de alteração, foram calculados os valores dos coe ficientes de alterabiliaade específica, que se encontram na tabela 25 - Os valores deste coeficiente variaram de $10^{-3}$ a 1 , o que permitiu diferenciar as diversas rochas quan to à maior ou menor suscetibilidade face às diferentes soli citações impostas peios ensaios, que podem ou não se mani festar em um determinado ambiente. 
De um modo geral, rochas com resistêncị as mecânicas inicjais elevadas aproximadamente $90 \%$, se mostraram resis tentes a todos os processos de alteração efetuados, como se pode verificar na fig. 59 . Dos ensaios de laboratörio, o ensaio de alteração com sulfato de söaio se revelou como o mais ativo, enfrquecendo a grande maioria das rochas. 0 en saios de alteração com etilenoglicol se mostxou mais sensivel às rochas portadoras de argilominerais expansivos, como era de se esperar. Entretanto, aparentemente, nas rochas não portadoras de argilominerais expansivos, este ensaio atuou semelhantemente ao ensaio de alteração por saturaçãosecagem. O ensaio de alteração via Soxhlet se mostrou, de um modo geral, como o processo majs lento de alteração acelerada.

Os valores de suscetibilidade das rochas aos diferen tes processos de alteração permitem ainda observar que, as particularidades texturais das rochas, alëm de sua mineralo gia, đevem relacionar-se com as suas resistências à alteraÇã. De um moảogrel, rochas compactas, menos microfissura das e de granulação fina com grãos bem imbricados, apresencaram comportamentos satisfatórios perante a alteração $\left(\mathrm{K}=10^{-3}\right.$ a $\left.10^{-2}\right)$. Por outro lado, rochas de granulação mé dia a grossa, xistosas ou estratificadas, ou com cimento, apresentaram coeficiente de alterabilidade especifica da or de de $K=10^{-2}$ a 1 , portanto, de comportamento méaio a não satisfatōio ( $K=1$, rocha totalmente alterada e portanto, de resistência mecânica nula).

Em todos os processcs de alteração estudados, a água deve ter sido um dos agentes que afetaram em maior ou menor grau, os resultados dos ensaios. A reatividade rochas $x$ água resulta da reatividade de cada constituinte mineralögi co à ägua e da interação das diversas reações na matriz rochosa. A anālise geoquímica do processo, embora imprescindí. vel na compreensão dos mecanismos de alteração, não serä abordada neste trabalho pois, um dos objetivos principais foi a avaliação mecânica da alteração, qualquer que seja o 
agente responsāvel. Assim, um indice que reflete mecanica mente a interferência da ägua no seu valor, é a relação en tre a resistência à compressão saturada e a seco, que é conhecido impropriamente como coeficiente de enfraquecimento (40-48). Este coeficiente varia de 0 a 1 . Quando for igual a zero, a resistência a compressão sacurada é igual a zero e quando for igual a unidade, a resistência a compressão sạ turada é igual a resistência a compressão seca.

Tendo em vista a importância da àgua nos processos -. de alteração, nas condiçöes de utilização e mesmo nos en saios de alteração efetuados, procurou-se correlacionar os valores dos coeficientes de alterabilidade específica das rochas para os diferentes processos de alteração, com os coeficientes de enfraquecimentos cálculados, com a finalida de de encontrar um novo parametro que permita estimar a terabilidade de rochas. Dc mesmo modo, foi efetuada a corre lação entre os coeficientes de enfraquecimento e a resistén cia Treton inicial, para se complementar açuelas relaçoes.

os resultados obtidos através da análise de regresuöo pelo método dos minimos quadrados para eslas correlações, en contram-se relacionados na tabela 26 . Os coeficientes de correlação encontrados incicam que a melhor correlação para estas variäveis è basicamente a relaçâo linear. As retas de regressão, traçadas a partir das equações, entre os coeficientes de alterabilidade especitica e os cceficien tes de enfraquecimento, permitem observar que (figs. 60 a 63 ):

1. Quanto maior o coeficiente de enfraquecimento, me nor é a alterabilidade da rocha, isto é, quanto rienor for a suscetibilidade à ägua da rocha, menor será sua suscetibili dade aos processos de alteração.

2. O ajuste da linha teórica aos pontos obtidos é me thor para rochas de coeficiente de enfraquecimento elevado (acima de 0,7 ).

3. O melhor ajuste da linha teórica foi obtida para - coeficiente de alterabilidade especifica do ensaio cie al- 
teração por lixiviação contĩnua $(r=0,85$ e sy $x=0,05)$.

A relação entre o coeficiente de enfraquecimento e a resistência Treton inicial (fig. 64 ), indica que apesar do baixo coeficiente de correlação e do elevado erro pa drão da estimativa, os pontos acham-se razoavelmente ajusta dos à linha teórica. Entretanto, esta anälise necessita de maior volume de dados para confirmação. 


\section{VII. - CONCLUSÕES GERAIS}

As conclusões mais importạntes e observações pertinentes ob tidas como resultado desta pesquisa apresentam-se resumidas nos seguintes parágrafos:

1. Os resultados desta investigação indicam que os ensaios com o esclerônetro schmidt podem ser apiicäveis a rochas, como estimativa de suas resistências mecânicas. Sua aplicabilidade ë indi cada pela:

a. Suas relações com propriedades constantemente citadas em especificações para emprego de rochas: resistência à compressäo uniaxial e resistência à abrasão Los Angeles.

b. Suz simplicidade, baixo custo e rapidez na determinação

c. Sua reprodutibilidade

2. O método de ensaio de impacto em corpos de prova regulam res, ASTM D3-18, sofreu modificações quanto à forma do corpo de prova e no mínimo de corpos de prova. Possivelmente, a aplica bilidade deste ensaio na estimativa da resistência à compressão uniaxial de rochas poderá ser melhorada com maior volume de da dos.

3. O ensaio de desgaste à ümido proposto por Franklin, J.A. e outros (17), revelou-se muito pouco sensivel, devendo ser aplicável para rochas de caracteristicas tecnológicas mais po bres. Alëm disso, para uma padronização adequada deste ensaio ë necessário um melhor conhecimento de suas variāveis, tendo em vista algumas discordâncias encontradas em relação à duração e no de ciclos.

4. Os ensaios de alteração devem ser efetuados sempre que possivel ra granuláção de uso do material (devido ao fator de escala). Caso conträrio, pode-se ensaiar em outras frações desae que se conheça a lei de variação.

5. A comparação de diferentes ensaios de alteração em laboratório, mostrou que o ensaio que imprime maior velocidade de alteração é o de alteração com sulfato de sōdio, que afetou praticamente todas as rochas.

6. De um modo geral, rochas de alta resistência mecânica - 
inicial, são pouco afetadas pelos processos de alteração.

7. O coeficiente de enfraquecimento ( $C E=\sigma s a t / \sigma s e c o)$, apre senta-se ccmo um Indice promissor para estimativa da alterabilidade de rochas, tendo em vista as razoāveis correlaçốes obtidas na anālise de regressão.

8. A resistência ao impacto Treton reveloumse um indice sen sível às variações do estado de alteração.

9. O coeficiente de alterabilidade especifica permite dis tinguir as rochas quanto à maior ou menor suscetibilidade em resistir aus processos de aiteração, em 3 categorias:

a. $K=10^{-3}$ a $10^{-2} \rightarrow$ rochas de baixa alterabilidade

b. $\mathrm{K}=10^{-2}$ a $10^{-1} \rightarrow$ rochas inedianamente alteräveis

c. $K=10^{-1}$ a $I \rightarrow$ rochas muito alteräveis.

10. Quanto à validade dos ensaios de alteraçäo acelerada,ob servou-se que ocorre uma atuação seletiva em rochas de naturezas diversas (uns poein a trabaihar mais a composição mineralógica, ou tros mais a estrutura). Para exemplificar, citamos o caso de ro chas de alterabilidade quase nula para um determinado processo, em xelaçăo a un outro: enguanto un dos processos de alteração aceleracia pode atuar positiva e eficazmente sobre uma determinaäa rocha, um sutro processo poderă não ter quase nenhuma influên cia sobre a mesma rocha. Nestas condições, considerando a conclu são do Item 6., podemos dizer que: os diferentes processos de alteração acelerada só poderão ser comparados na nedida que re iletirem as mesmas ações ou cordições fisicocuímicas. Alëm disso, a não reprodução de condições naturais não jnvalida um determina do processo de alteração. Estes processos, deverão antes de tudo serem encarados como simples mëtcolos de ensaios destinados a solicitar as rochaś ém seus aspectos mais suscetíveis, seja a composição mineralógica, seja o seu estado de fraturamento, crue poderão ser ativaâos por condições particulares (representados felos ensaios), eque poderão ou não se manifestar em um determi nado ambiente.

11. De acordo com o que foi verificado, pode-se concluir que uma anälise petrográfica detalhada, e um ensaio mecânico co mo o ensaio de impacto Treton serão excelentes guias para a esco 
- Iha do melhor ensaio de alteração para aquela rocha. Caso o re sultado no ensaio mecânico seja elevado (evidenciando präticamen te a ausência de qualquer fraqueza estrutural), o ensaio de alte ração escolhicio deverá solicitar de alguma forma a composição mineralógica daquela rocha.

12. Considerando os resultados de ensaios fisicomecânicos e os coeficientes de alterabilidade especifica, as rochas segura mente aprovadas para material de construção em geral são: basalto de Olimpia, basalto Serra de Brotas, diabäsio de Campinas, miq matito de Jaborandi, basalto de Ilha Solteira, granito são de Anhanguera e calcärio Apiar. As rochas de características intermediärias, de emprego restrito são: basalto "A" de Capivara, quartzito Jequitaí, calcário do Rio Grande do Sul, granito Sacos, basalto de Salto Osório, charnockitode ubatuba, granito alterado de Anhanguera e piroxenito de Niquelandia. Finalmente, as rochas não recomendäveis para qualquer finalidade são: arenito Bauru e os basaltos "B" e "C" de Capivara. 
VIII. - RECOMENDACOES PAPA PESQUISAS PUTURAS

Inumeras sugestões para estudos futuros surgiram durante o desenvolvimento deste traballo. Algumas destas, podem consti tuir-se numa continuação natural do presente estudo, enquanto que outras, são observações isoladas, que podem ser desenvolvi das. As recomendações sugeridas encontram-se. comentadas nos pa rägrafos seguintes:

1. são necessärios ensaios adiciorais sobre uma maior quan tidade de rochás para os novos indices investigados: indice es cleromëtrico, resistencia ao impacto e resistência a desgaste a umido. Os novos resultados poäerão auxiliar na verificação ou modificaçâo áas curvas de regressăo de forma a aumentar o nivel dè significancia.

2. Existein atualmente diversos mëtodos para estudo de pro priedades fisicas de rochas mas, frequentemente, os valores de termirados são inconsistentes. o objetivo da tecnologia de ro chas é então. o de encontrar nëtotos comuns para a determinação de caracteristicas tecnológicas. Os principajs requisitos dese jāreis de tais mëtodos são os seguintes (40):

a. Possibilitar a determinaçãc de propriedades a partir de grandes corpos de prova.

b. Possibilitar a determinação de um nümero náximo de pro priedades a partir de um nümero minimo de amostras.

c. Possibilitar uma coinbinação de operações em um ünico cor po de prova para determinar diferontes propriedades.

d. Possibilitar a determinação de propriedades em condiços de diferenies campos externos (naturais e artificiais).

3. Como vimos, as jescontinuidades de rochas em quaisquer dimensões, desempenham papel fundamental nos processos de alteração. Possivelmente uma correlação estatística entre os valo res que definem o campo microfissural e os valores de alterabilidade especifica encontrados neste trabalho, poderá constituir se em um teste de validade para estes parametros.

4. O ensaio de resisuencja ao impacto Treton mostrou-se sensivel às variações do estado de alteração. Entretanto, para que tenhamos uma lei geral de comportamento mecanico face à a 
teração, é necessáxio efetuar ensajos comparativos utilizando se värios parametros mecanicos.

5. Jä vimos que um dos fatores que afetam sensivelmente os resultados dos ensaios de alteraçào é o fator de escala. As cur vas de $\%$ de perda acumulada $x$ superficie especifica permiten so licionar em parte este problema, atravēs da extrapolação de re sultados tanto para amostras de granulometrias maiores quanto para as menores. Entretanto, o iimite de validade destas extrapolações para amostras cie grandes dimensões fica indeterminado e c ensaio se torna impraticävel. Possivelmente a execução de ensajos sismicos "in situ", medindo-se a queda da velocidade de propagação äe onảas com a alteração poderá contornar este incon veniente.

6. Até o romento, todos os ensajos de alteração, como são entendidos por nōs, são destinados a evidenciar as fraquezăs das rochas nos seus aspectos meis suscetiveis. No entanto, pouco se sabe sobre o effeitc leal da desagregação de rochas colocadas em diferentes condições de serviço. Para isto, a realizaçäo de ensaios de alteração e medila do comportamento mecanico em corpos de prova conieccionados para estruturas (concretos e pavi... nentos), com agregadus rochosos de caracteristicas tecnolögicas conhecidas, poderá cortribuir grandemente nos critërios de esco Iha e dimensionairiento de quaisquer volumes de rochas para vā rias finalidades. 
1. Aires Barros, I. (1970) - "Note preliminaire sur un indice d'alterabilité" - Ist Intern. Cong. of the Intern. Assoc. of Eng. Geol., Tome I, theme 4, pp. 573-577, Paris.

2. Aires Barros, L. (1971) - "Alteração e alterabilidade de ro chas Igneas" - Laboratório Nacional de Engenha ria Civil, Lisboa, 1971.

3. ASTM D-3-18 (1918) - "Resistência ao impacto" - American So ciety for Testing Materials, Pniladelphia.

4. ASTM (1948) - "Symposium on mineral aggregates" - American Society for Testing Materials, Fifty-tirst Annual Meeting, Detroit.

5. ASTM-C88-69 (1969) - "Soundness test" - American Society for Testing Materials, Philadelphia.

6. Bernaix, J. (1967) - "Etude geotechnique de la roche de Malpasseill-Dunod, Paris.

7. BS 812 (1967) - "Methods for sampling and testing of mireral aggregates" - British standards Instiwution, London.

8. Chefdeville, J. (1955) - "La resistance à la compression du bëton, sa mesure par la méthode d'auscultation dynamique" - Annajes du I.T.B.T.P. NQ 95 , Paris.

9. Chevassu, G. (1969) - "Influência das caracteríscicas petro gräficas de várias rochas sobre a resistência ao atrito" - Bull. Liaison Labo. Routiers P. et Ch. no 59 , julho-agosto; 1969.

10. Considine, D.M. e Ross, S.D. (1964). - "Haildbook of Applied Instrumentation" - McGraw-Hill Book Company, New York.

11. Day, H.L. (1962) - "A progress report on studies of degrading basalt aggregate bases" - HRB Bulletin $344, \mathrm{pp}$. 8-16. 
12. Deere, D.U. e Millex, R.P. (1966) - "Engineering classifica tion and index properties for intact rock" Air Force Weapons Lab., Technical Report-AFWLTR-65-116, Kirtland, New Mexico.

13. DNER (1971) - "Mëtodos de ensaios" - Divisão de Pesquisas Tec nolögicas do Departamento Nacional de Estradas de Rodagem, Rio de Janeiro.

14. Farjallat, J.E.S. (1971) - inédito - "Estudos experimentais sobre a degradação de rochas basälticas" - In tituto de Geociencias - USP, são Paulo.

15. Farjallat, J.E.S. e Nery de Oliveira, I.A. (1972) - inédito "Experimental studies on the weatherability of the Capivara Dam basalts, Rio Paranapanema, Brazil" - Bull. of the Intern. Ass. of Eng. Geol., Paris.

16. Farran e Thenoz (1965) - "L'alterabilité des roches, ses facteurs, sa prevision" - Annales I.T.B.T.P., Novembre, 1965 - Paris.

17. Franklin, I.A.; Brock, E. e WaIton, G. (1971) - "Logging the mechanical character of rock" - Trans. Inst. Min. Metal1. 80, Al-Alo.

18. Franklin, J.A. e Chandra, R. (1972) - "The slake-durability test" - Int. J. Rock Mech. Min. Sci. vol. 9, Pp. 325-34I, Pexgamon Press, Great Britain.

19. Gitahy, H.S. (1960) - "Controle estatístico da qualiciade do concreto" -- Instituto de Pesquisas Tecnológi cas, Bol. no 49 , são Paulo.

20. Goni, I.; Ragot, J.P. e Sima, A. (1968) - "Méthodes d'étude du champ microfissural des minéraux et des roches et possibilités d'application en gëologie" - Bulletin du B.R.G.M. (deuxième sê rie), Section II ne 4, 1968, p.51-92.

21. Habib, P. e Bernaix, J. (1966) - "La fissuration des roches"Proc. $1^{\text {st }}$ Congress of the Int. Soc. Roc. Mech. 
VoI. 1 , pp.185-190.

22. Hamrol, A. (1962) - "A quantitative classification of the weathering and weatherability of rocks" - 5 th Intern. Conf. Soll. Mech., Vol.2, pp.771-774, Paris.

23. Hawkes, I. e Mellor, M. (1970) - "Uniaxial testing in rock mechanics" - Engineering Geology, vol. 4, no3, julho de 1970 .

24. HRB (1970) - "Degradation of aggregates" - no 51, Research Board, Washirgton.

Highway

25. Iliev, I.G. (1966) - "An attempt to estimate the degree of weathering of intrusive rocks from their physi co-mechanical properties" - Proceedings of the first congress of the Intern. Soc. Rock Mecha nics, pp.109-114, Lisboa.

26. Javey, C. (1972) - "L'altération des roches et des monuments Etude documentaire" - Bull. B. R.G.M. (2) III, 1., pp. 39-66.

27. Kolek, J. (1968) - "Using the Schmidt rebouna hamner" - Con crete, vol.2, no10, October.

28. Kolek, J. (I@69) - "Analysis of answers to Rilem questionaire on the Schmidt Rebound Hammer" - Materiaux et Constructions, Juillet waut, n810.

29. Leme, R.A.S. (1965) - "Curso de Estatistica" - Ao Livrc Técni co.s.A., Rio de Janeiro.

30. L'Hermite, Robert (1966) - "Methodes gërērales d'essai et de controle en laboratoire" - Institut Techniqua de Batiment et Travaux Publics, I.T.B.T.P.; Pa ris.

31. Morais Rego, L.F. e Souza Santos, T.D. (1938) - "Contribuição para o estudo dos granitos da serra da Canta reira" - Bol. no. 18, Instituto de Pesquisas Tecnológicas, jurho 1938, são paulo. 
32. Pëdro, G. (1964) - "Contribution à I'ëtude expéximentale de I'altëration gëochimique des roches cristali nes" - Ann. Agro. 2-3-4, 344 p.

33. Pichler, E. (1942) - "A petrologia e os ensaios tecnológicos de rochas" - Bol. Dep. Estradas de Rodagem, são paulo.

34. Prevosteau, J.M.; Ragot, J.P. e Sima, A. (1970) - "I.e spèctre de porosité des rocies-critëre possible de leur degré d'alteration et de leur alterabili té" - Io Int. Congr. Inst. Ass. Eng. Geology, pp. 548-560, Paris.

35. Programa EPC-7 (1972) - "Usina de Água Vermelha - proposta pa ra um ensaio de durabilidade de maceriais ro chosos" - Instituto de Pesquisas Tecnológicas, são Paulo.

36. Ramsay, D.M. (1965) - "Factors influencing aggregate impact value in rock aggregate" - The Quarry Maragers' Journal, April 1965, pp. 129-134.

37. Robert, M. (1970) - "Etude experimentale de la desagregation du granite et de l'evolution des micas" - Fa cultē des sciences de paris.

38. Rocha, M. (1971) - "Mecänica das Rochas" - Lab. Nac. Eng. Ci vil, Iisboa.

39. Ruiz, M.D. (1.966) - "Caractexisticas tecnolögicas de rocias do Estado de são Paulo" - Bol. ne 50, Instituto de Pesquisas Temolögicas, são Paulo.

40. Rzhevsky, Y. e Norik, G. (1971) - "The physias of rocks"-Mir Publishers, Moscow.

41. Schneider, A.W. e Rocha, F.X.P. (1968) - "Emprego de basaltos em pavimentação rodoviäria" - Instituro de Pes quisas Rodoviārias, Publicação 433,42 p., Rio de Janeiro.

42. Sigvaldason, O.T. (1964) - "The influence of the testing ma chine on the compressive strength of concretel 
Proc, Symp. Concrete control, ist. Imperi al College, pp.62-171, London.

43. Spiegel, M.R. (1971) - "Schaum's outline of theory and prob lems of estatistics" - Tradução Pedro Consenti no, Editora MoGraw-Hill do Brasil Ltd., Rio de Janeiro.

44. Struiliou, R. (1969) - "Prevision de l'alterabilité des matëriaux employeēs en Gënie Civil" - Coloque de Gëotechnique, Mars-1969, pp. 35-46, Toulouse.

45. Talobre, J.A. (1967) - "I ma mécanicue des roches" - Ed. Dunod, Paris.

46. Thénoz, B. (1966) - "Contribution a l'ētucie de la perméabili té des roches et de leur altérabilitë" - Appli cation a des roches granitiques, Facultē des Sciences de l'université de Toulolise.

47. Vollmex, E. (1967) - "Encyclopaedia of hydraulics, soij and foundation engilleering" - Elseviex Publishing Company.

48. Vorobiev, V. (1967) - "Matériaux de construction" - Edition Mir, Moscow.

49. Weinert, H.H. (1964) - "Lasic igneous rocks in road founda tions" - Irational Institute for Road Research, Bull. n.5, Pretoria, South Africa.

50. West, T.R.; Johrison, R.B. e Smith, N.M. (1970) - "Test for evaluutirig degradaition of base course aggre gates" - Natioral Cooperative Highway Research Program, Report 38,92 w. Washington.

51. White, C.G. (1909) - "A rock drillability index" - Quarterly of the Colorado school of Mines, vol. 64,n?2.

52. Yoshida, R.; Frazäo, E.B. e Giroldo, A.M.P. (1972) - "Revisão cxitica dos métodos de ensaios de forma de fragmentos" - Anais da IV Semana Paulista de 
Geologia Aplicada, 1972, são paulo (no prelo). 53. Yoshida, R.; Farjallat, J.r.S.; Caruso, L.G. e Frazão, E.B. (1972) - "Sugestão de roteiro e escolha de en saios tecnolögicos." - Anais da IV Semana Paulis ta de Geologia Aplicada, 1972, são Paulo, (no prejo). 
APENDICE A

DESCRIÇÕES PETROGRÄEICAS E EOTOMICROGRAFIÄS

DE SECÇÕES DELGADAS DAS ROCHAS ESTUDATAAS 


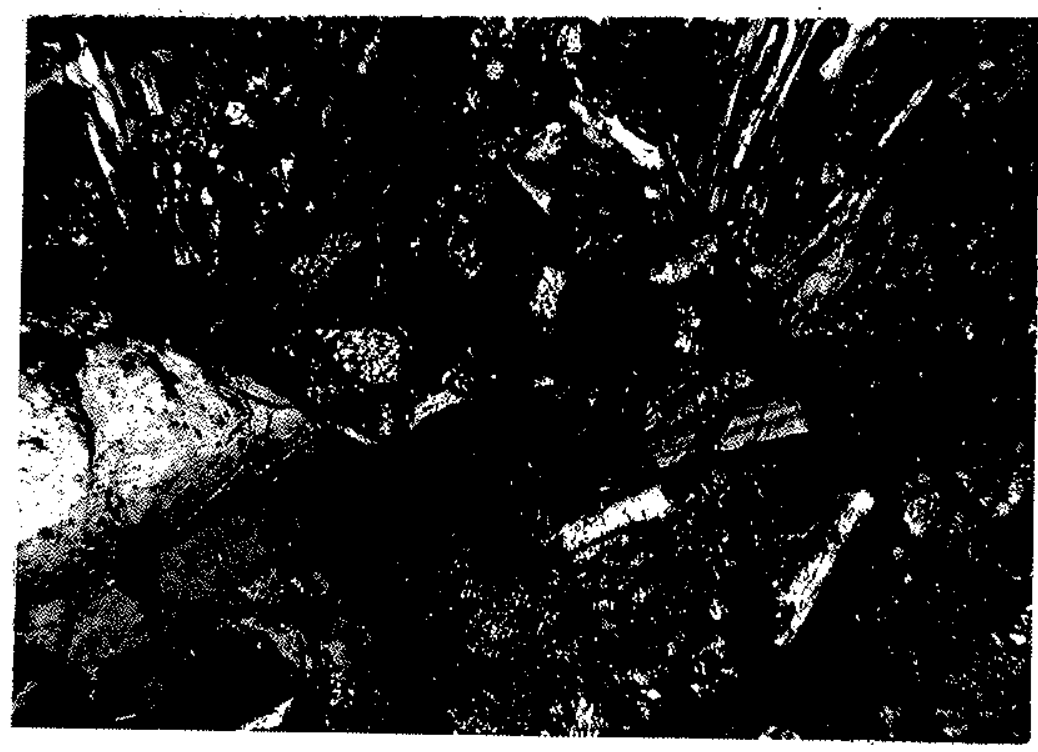

Fotomi crografia - $170 \mathrm{x}$, nicóis cruzados AMOSTRA NO 1 - BASALTO "A" DA BARRAGEM DE CAPIVARA

Basalto compacto, afanitico, homogêneo, não orientado, de cor cinza escuro esverdeado. As amostras estudadas não apresenta vam fraturas macroscopicamente visiveis. A textura e granular, ruj crosristalina e oligohialira (hipocristalina). O plagioclásio(1 bradorita An60) é ripifomme, normalmente idionorfo, finamente geminado segundo albita e albita-Carlsbad. Os piroxênios (augita $2 V x \sim 50^{\circ}$, são hipidiomorfos e xenomorfos, intergranulares. Os cristais são suhmilinétricos $(0,1$ a $0,2 \mathrm{~mm})$ ocurrendo alguns cristais milimëtricos de plagioclásio e piroxênio. Observa-se tambēm um material vítreo ou parcialmente desvitrificado. Mine rais esverdeados identificados como rontronitu ocorrem preenchen do os intersticios, ocupando a mesma situação textural que o vi dro. O mineral acessório é magnetita ou magnetita titanífera iaio morfa e tambëm esquelëtica. Ocorre apatita acicular associada ao feldspato, vidro e'argi ia.

A anälise modal, média de 3 amostras, apresentou:

$\begin{array}{ll}\text { Augita } & -37,2 \% \\ \text { Labradorita } & -38,7 \% \\ \text { Nontronita (+ vidro) } & -15,2 \% \\ \text { Vidro } & -3,5 \% \\ \text { Magnetita } & - \\ \end{array}$

Rocha com alteração apenas incipiente. 


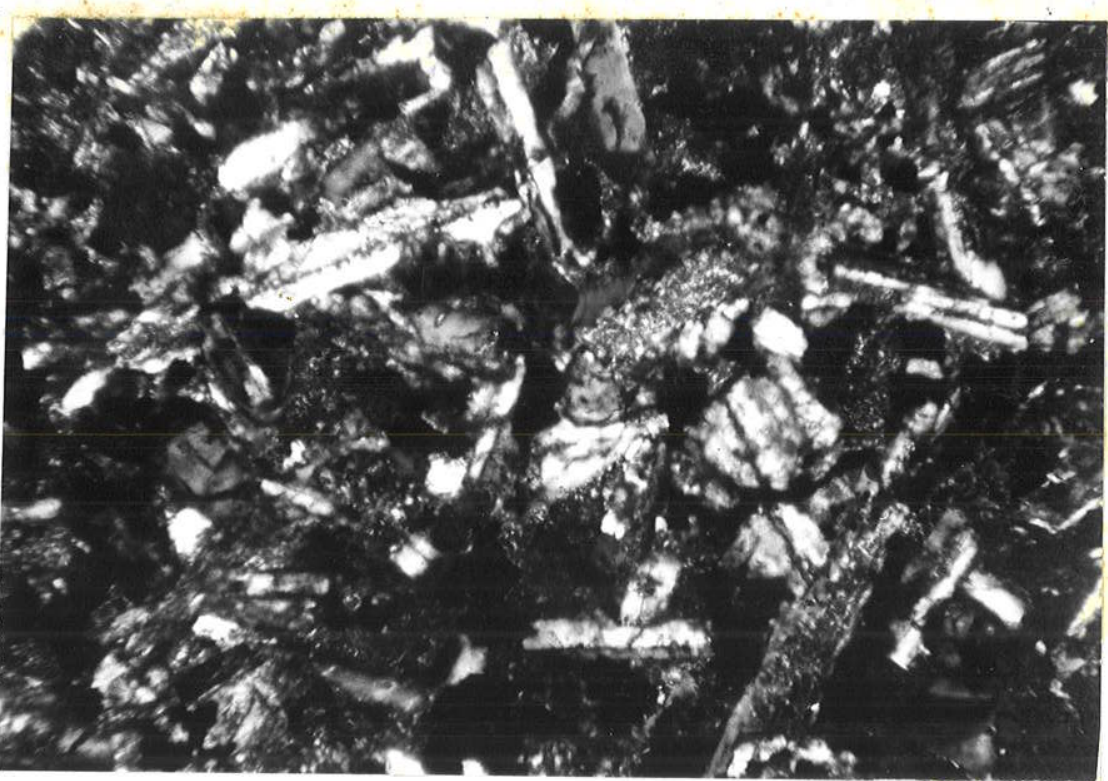

Fotomicrografia - 170 x, nicóis cruzados AMOSTRA NO 2 - BASALTO "B" DA BARRAGEM DE CAPIVARA

Os basciltos tipo B são basaltos vesiculares e/ou amigdaloidais caracteristicos do topo de derrames. As amígdalas ou vesícu las são de dimensões variáveis de milimetros a alguns centímetros. Ocupam em volume 20-25\% da rocha. A rocha estudada é afanítica, de cor cinza escuro a castanho avermelhado. As amígdalas são preenchidas por zeólitas, quartzo; calcita, calcedônia e montmorillonita.

A análise modal típica apresenta:

$\begin{array}{ll}\text { Augita } & -20,8 \% \\ \text { Labradorita } & -30,2 \% \\ \text { Minerais argilosos verdes (+ vidro) } & -34,0 \% \\ \text { Magnetita } & -9,2 \% \\ \text { Zeólita e calcedônia } & -5,8 \%\end{array}$

A textura é mal cefinida, tendendo a vitrofírica. A granula ção varia principalmente no intervalo 0,25 - 0,5 mm.

A rocha é pouco alterada, caracterizando-se a alteração principalmente por limonitização. 


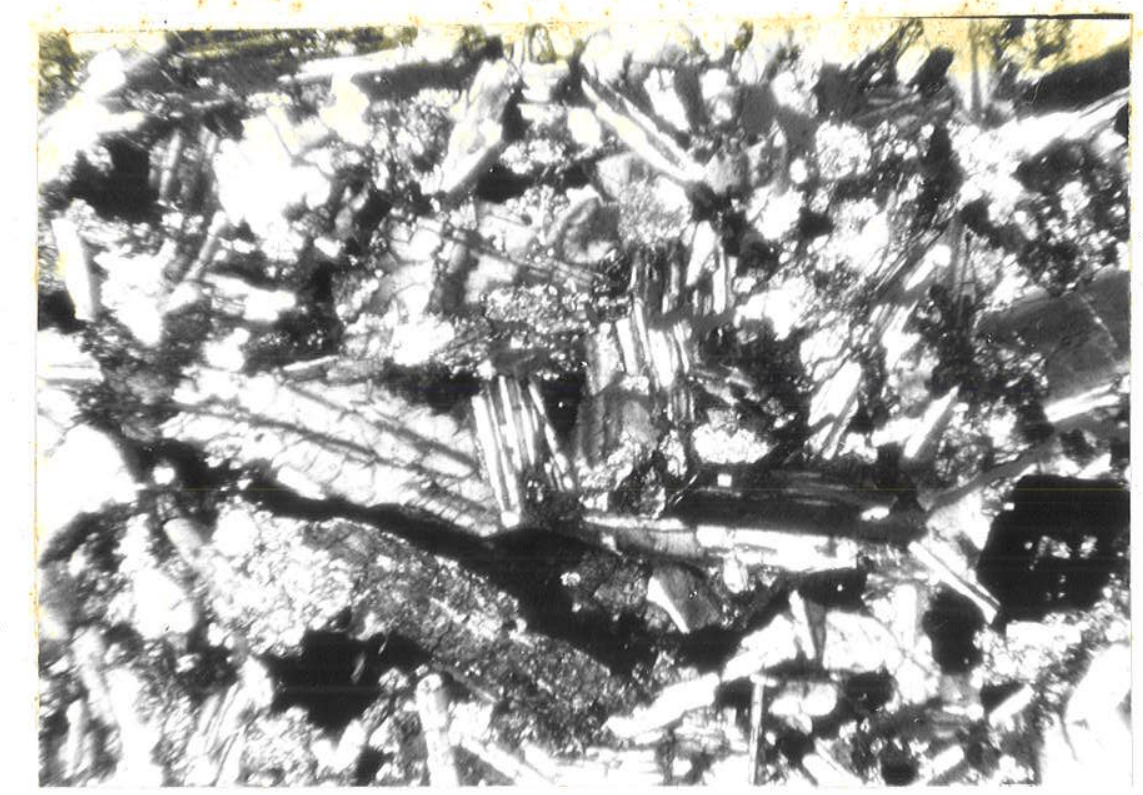

Fotomicrografia - $60 \mathrm{x}$, nicóis semi-cruzados

AMOSTRA NO 3 - BASALTO "C" DA BARRAGEM DE CAPIVARA

Basalto compacto, fanerítico, granulação fina, cox cinza më dio esverdeado. A labradorita e a augita apresentam característi cas ópticas semelhantes aos da rocha tipo A. A granulação da ro cha é urn tanto variävel, incoo de 0,4 a 0,7 e mesmo $1 \mathrm{~mm}$. A texiu ra é semelhante à da rocha tipo A. A quantidade de nontronita é variävel, alcançando atë $35 \%$ em volume, porém os valores mais cornuns estão próximos a 10-15\%.

A anáiise modál, média de 12 amostras, apresentou:

Augita - 33,1\%

Labradorita - 38,3\%

Nontronita $8,3 \%$

Vidro $11,5 \%$

Magnetita $\quad 6,7 \%$

Ocorre uma quantidade pequena e variável de minerais secundários, principalmente zeólitas, calcedônia e óxidos de Fe secun dários.

A rocha ミ mineralogicamente pouco alterada, caracterizandose a alteração principalmente por limonitização a partir da magnetita e do piroxênio. 


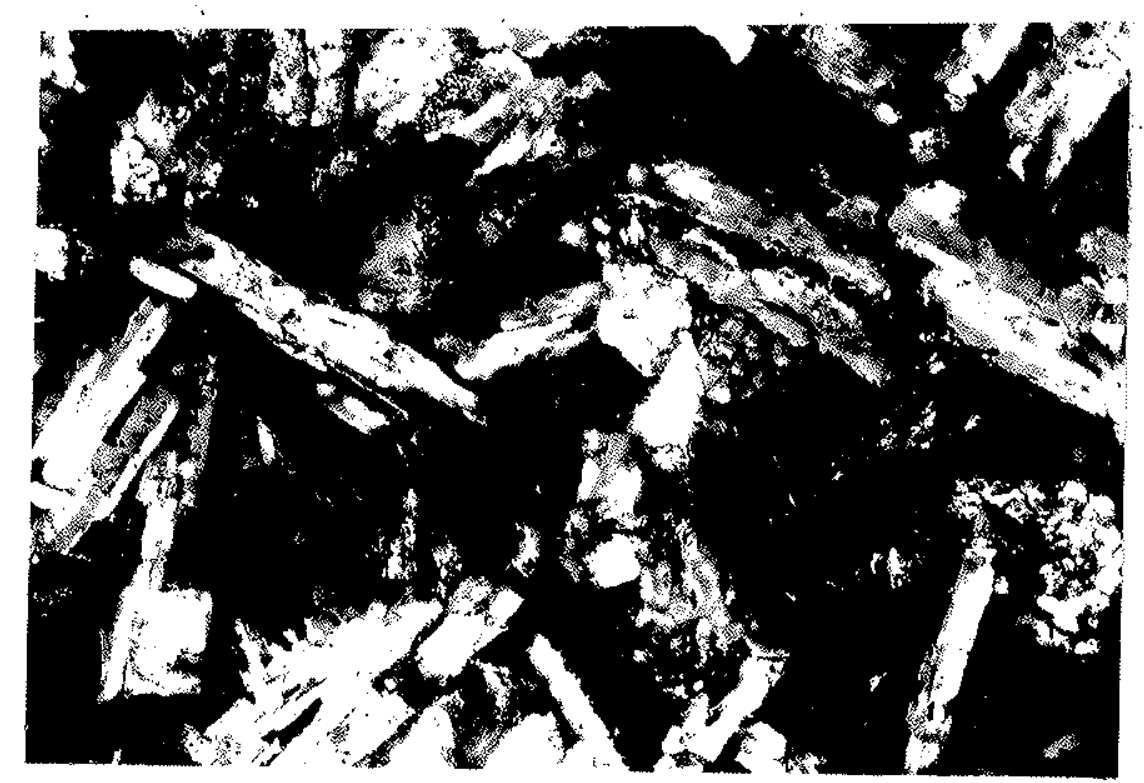

\section{Fotomicrografia - $425 \mathrm{x}$, nicöis semi - cruzados AMOSTRA NO 4 - BASALTO DE SALTO OSÓRTO}

Basalto vesiculo-amigdaloidal, cor castarho avermelhado, afa nitico. As amígdalas e vesículas são de dimensões variāveis, des de milimëtricos até alguns centimetros. A dimensão média está em torno de $0,5-0,8 \mathrm{~cm}$. A forma das vesículas e amígdalas é normalmente esférica ou ovalada, raramente alongada. Preenchem as amis. dalas os seguintes minerais: zeólitas, calcedônia e filossilicatos (clorita,montmorillonita e camada mista de clorita e montmorilionita).

A rocha apresenta poucas macrofraturas preenchidas e suldadas por minerais hiärotermais, principalmente calceaônia e zeóli tas. Os constituintes primários são:

I. Plagiocläsio - 40-50\% (labradorita) - praticamente apenas uma só geração, ripiformes, muitas vezes geminados e segundo al bita $\in$ albita-carlsbad, granulaçäo média $(0,1-0,15 \mathrm{~mm})$.

2. Clinopiroxênio - t 20\% (Augita) - uma só geração, intergranulares, elevada tendência a xenomorfismo, dimensões mëdias em torno de $0,03 \mathrm{~mm}$.

3. Magnetita ou magnetita titanifera - 5-7\% - hábito variävel, alongada e isodiamëtrica, esquelētica; dimensões variāveis, os alongados próximos ao plagioclásio e os não alongados próximos ao piroxênio.

4. Vidro e minerais secundärios - 20-25\% - vidro desviturifi cado em cristalitos não identificados e magnetita esquelética;mi nerais secundärios são zeölitas (heulandita ?), calcedônia. fi lossilicatos e óxidos de ferro (limonita e goethita). 


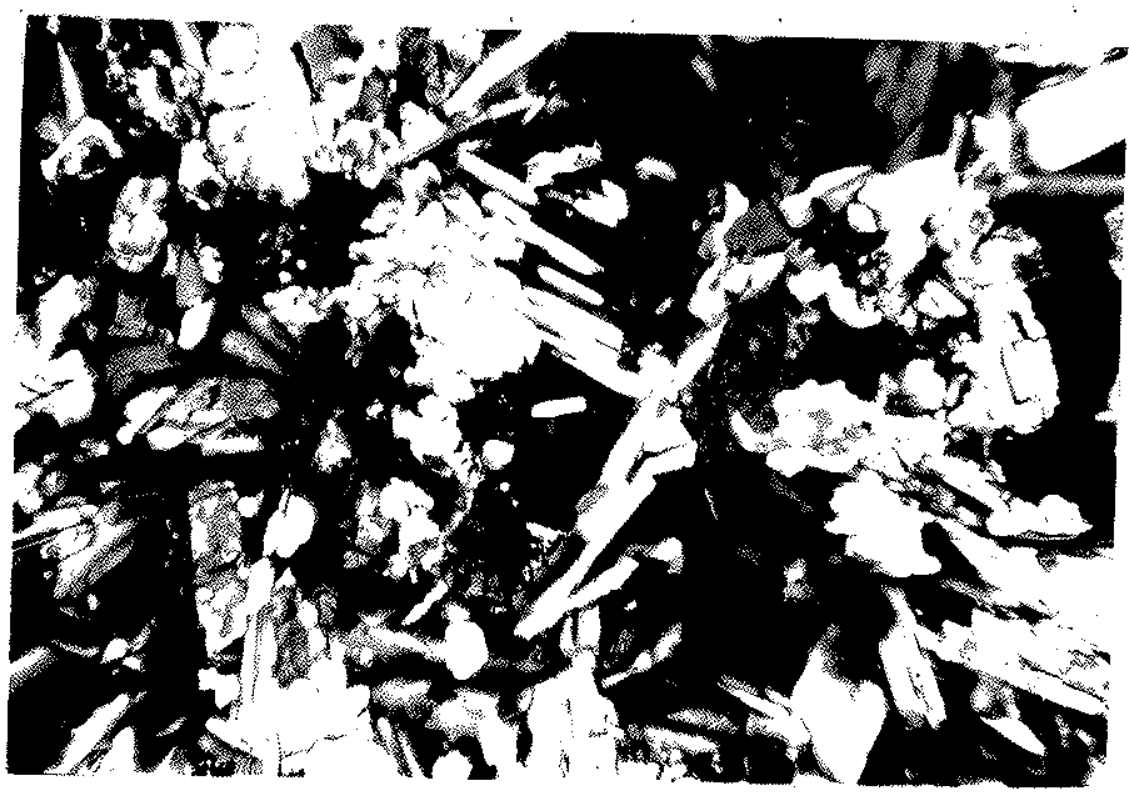

Fotomicrografia - $170 \mathrm{x}$, nicóis cruzados AMOSTRA NO 5 - BASRITO DE OLIMPIA

Basalto compacto, homogêreo, afanitico, cor cinzamescuro. Não se notam fraturas nas amostras em blocos.

Os minerais constituintes são:

1. Plagiocläsio - 35-45\% - Iabradorita ( An 60) - uma gera ção, idiomorfos, ripiformes, fine mente geminados (albita e albitaCarlsbad) $-0,15-0,2 \mathrm{~mm}$.

2. Piroxênio - 35-45\% - aucita e traços de pigeonita - haj to variâvel, normalmente alotricmor fos dimensões pröximas às do plagie cläsio.

3. Magnetita ou mag.titanifera. - 5\% - tendêrcia idiomörfi ca porëm grãos parcialmente reabsor vidos.

4. Vidro - 10\% - acastanhado, isótropo, apenas parcialmente recristalizado.

5. Minerais secundārios verdes - 5u10\% - 2 tipos: pseudomor fos de olivina (traços mineral serpentínico ?) intersticial - mineral montmo rilionitico.

Altexačăo - minerais praticamente sãos.

Textura - variável de subofítica a intergranular. 


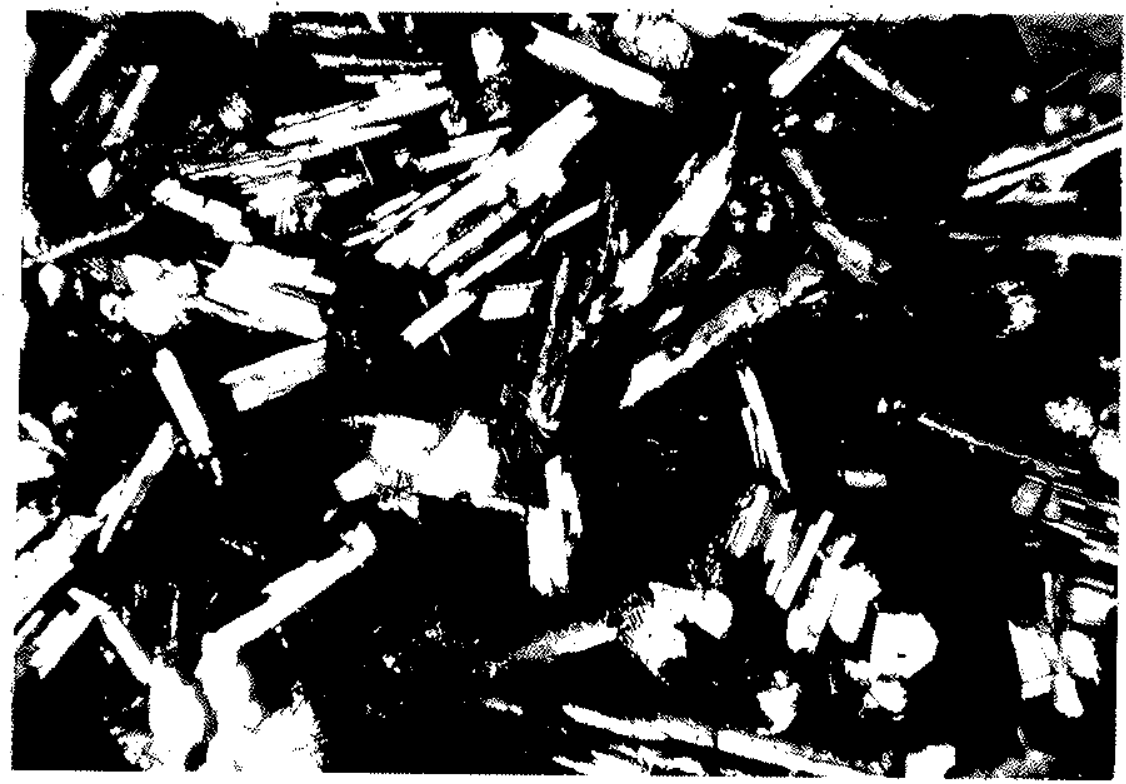

Foromicrografia - $170 \mathrm{x}$, nicöis cruzados AINOSIRA NO 6 - BASALTO DA SERRA DE BROTAS

Basalto compacto, homogeneo, afanitico, de cor cinza escu ro, quase preto. Apreserta fiaturas soldadas por minerais secun-
därios.

Os minerais constituintes são:

1. Plagioclásio - 30 a 35\% - (An 50-60) - Labradorita -idio morta, ripifcrme, finamente geminăo; apenas uma geração de mi crocristais; dimensão pröxima a 0,1.2 - 0,1.5 mm.

2. Piroxento - 20 a $30 \%$ - praticamente apenas augita intergranular, alotriomorfa; dimensões ligeiramente inferiores às do piagiuclásio. trica.

3. Magnetita (titanifera ?) - 3 a 5\% - idiomorfa, isodi amë-

4. Viaro 30: - desvitrificado, acastanhado, quase opaco, rico em magnetita esquelética e cristalitos.

5. Minerais secundārios verdes - ja loo - na sua maioria constituidos de argilas 2:1 expansivas, mas tambëm pseudomorfos de olivina. Ocorre normalmente de forma irtersticial.

Alteração - piroxênio e plagioclásin praticamente sãos. o vidro apresenta-se alterado e desvitrificado - traços de öxidos de $F e$ dispersos na rocha.

Textura - variävel de intergranular a vitrofirica. 


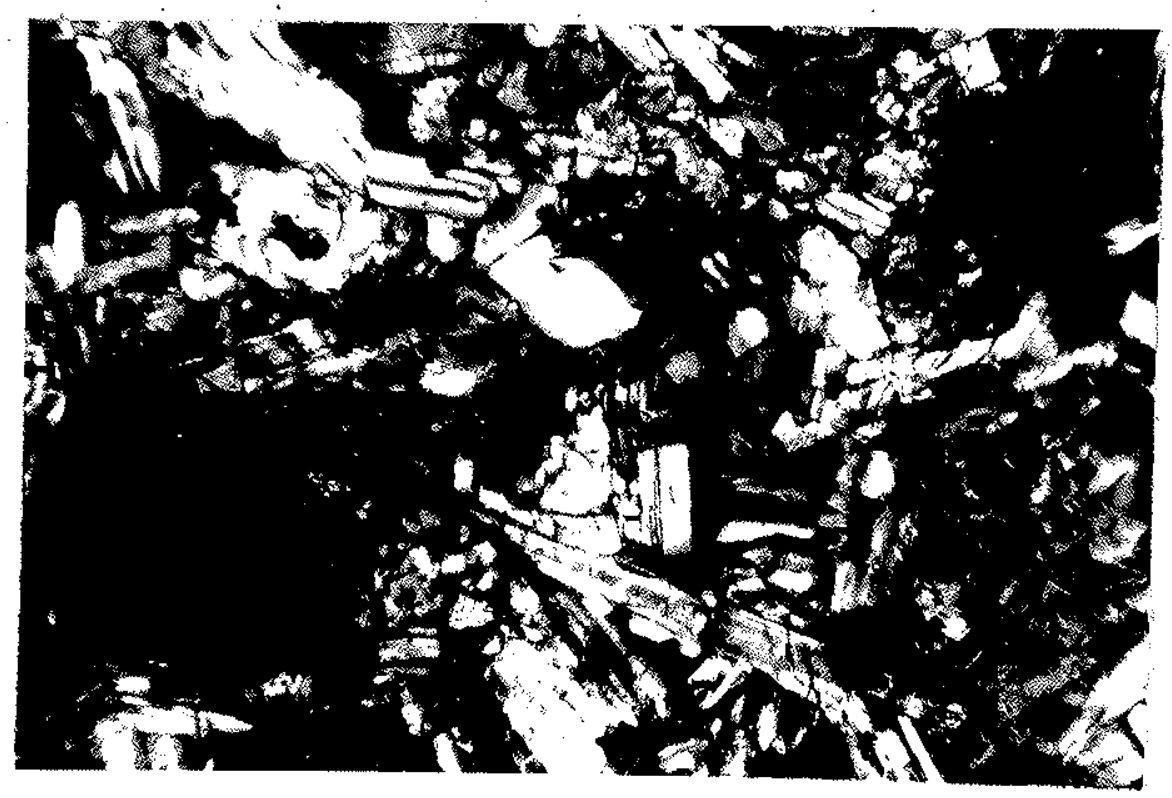

Fotomicrografia - $170 \mathrm{x}$, nicóis cruzados

AMOSTRA NO 7 - BASALTO DA ILHA SOLTEIRA

Basalto compacto, homogêneo, afanitico, de cor cinza escu ro esverdeado. As amostras estudadas não apresentaram fraturas macroscopicamente visiveis.

or minerais constituintes são:

I. Plagioclásio - 35 a 45\% (labradoritico) - composição pou co variāvel em torno de An 60; ocorce como microfenocristais (pou cos grãos) e como microcristais; estes são idiomorfos, ripifor mes, finamente geminados; dimensão mëdia em torro de 0,07 mm.

2. Piroxênio - 30 a $40 \%$ (augita e traços de pigeonita) - a augita tem tendência a xenomorfismo, porém a pigeonita muitas ve zes é idiomórfica; dimensões semelrantes à do plagioclásio.

3. Magnetita (titanífera) थ 5 a 7\% - grãos isodiamétricos, com tendência a idiomorfismo, poxëm com reabsorção.

4. Viaro 3-5\% - desvitrificado em cristalitos não identificados; cor acastanhada.

5. Minerais secundārios verde acastanhädos $\sim 5 \%$ - ocurrem 2 tipos:

a. Pseudomorfos de olivina (mimeral sexpentinico ?).

b. Filossilicato expansivo 2:I (montmorilionita)

Alteração - rocha com alteraçäo incipiente, caracterizanciose por limonitização de öxidos de Fe, alteração do vidro.

Textura - variāvel de subofitica a intergranular 


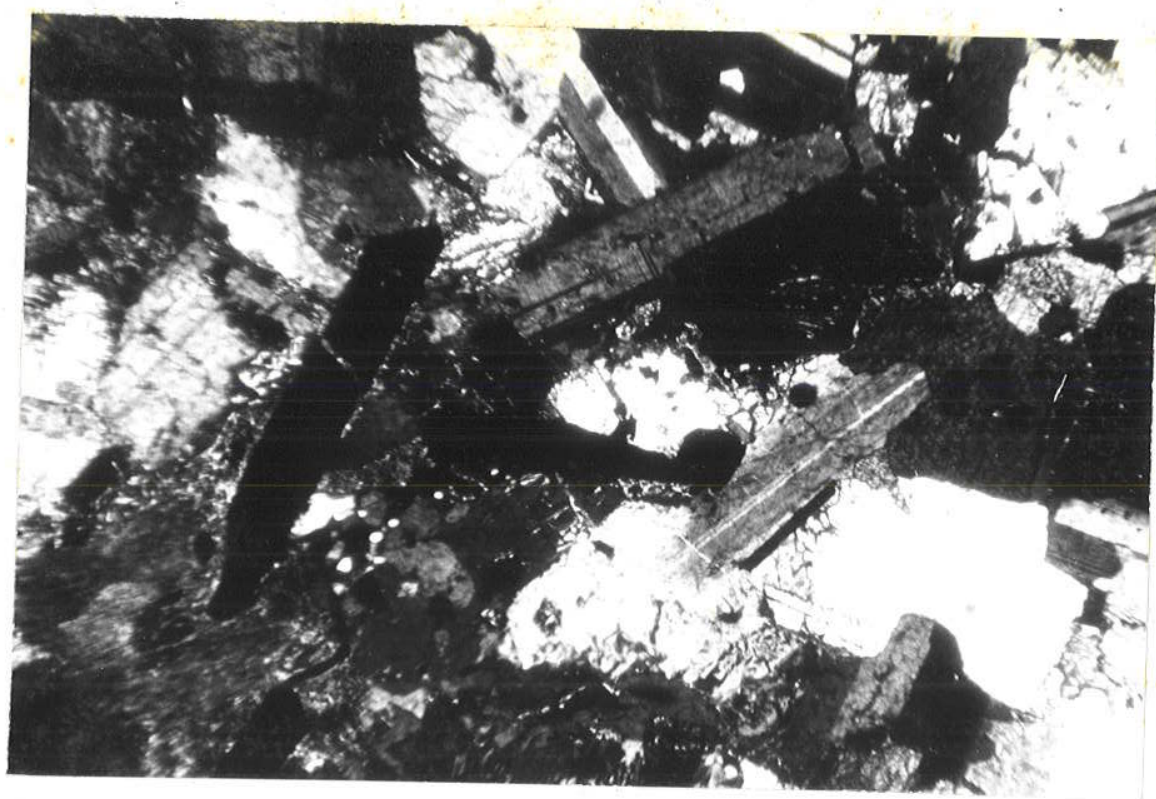

Fotomicrografia - $60 \mathrm{x}$, nicóis cruzados AMOSTRA NQ 8 - DIABĀSIO CAMPINAS

Rocha de cor cinza escuro a preto, compacta, homogênea, não orientada, fanerítica, granulação fina a média.

Segundo Hypolito ( ) é constituída de:

$\begin{array}{ll}\text { Plagioclásio (An } 55 \text { - 60) } & -45,4 \% \\ \text { Piroxênio (Augita e pigeonita) } & -25,6 \% \\ \text { Olivina } & -1,4 \% \\ \text { Ooacos (magnetita titanifera) } & -7,8 \% \\ \text { Intercrescimento gräfico } & -7,4 \% \\ \text { Minerais argilosos (nontronita) } & 5,6 \% \\ \text { Apatita } & -0,2 \% \\ \text { Anfibólio } & -2,6 \%\end{array}$

A granulação é um pouco variävel, com maior frequência de valores entre $1,5-2 \mathrm{~mm}$, porém ocorrem fenocristais com até $15 \mathrm{~mm}$ A textura é variável de subofítica a intergranular.

Alteração - alteração deutērica pouco acentuada, caracteri zando-se pela formação de anfibólio; alteração intempérica inci piente. 


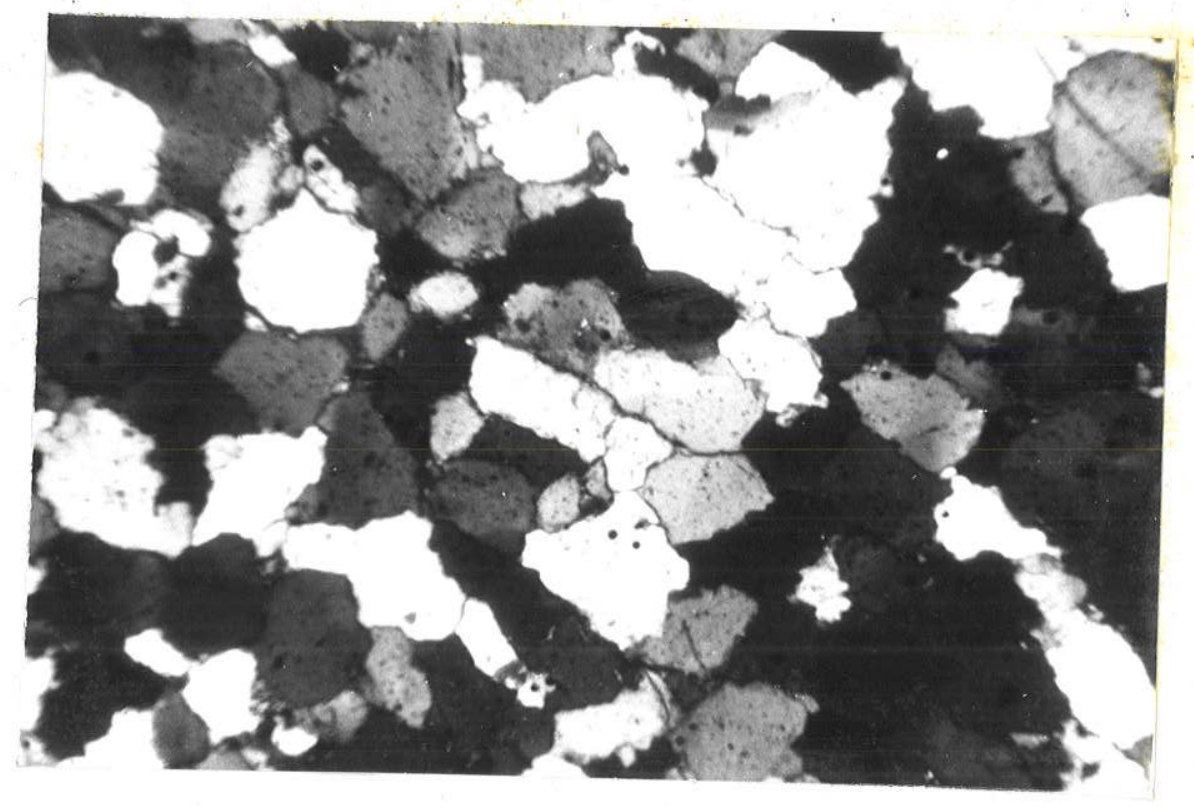

Fotomicrografia - 60 x, nicöis semi - cruzados AMOSTRA NO 9 QUARTZITO JEQUITAI

Rocha mal orientada, compacta, granulação muito fina, cor cinza claro a creme. Apresenta fraturas de pequena extensão, mui tas delas soldadas por quartzo.

A textura é granoblástica, equigranular,com interpenetração acentuada dos minerais. A rocha ’ constituida essencialmente de quartzo com extinção ondulante, de diâmetro médio próximo a $0,25 \mathrm{~mm}$. Possui ainda 3-5\% de feldspato sericitizado e 1-2\% de outros acessörios, incluindo um mineral opaco e zircão. 


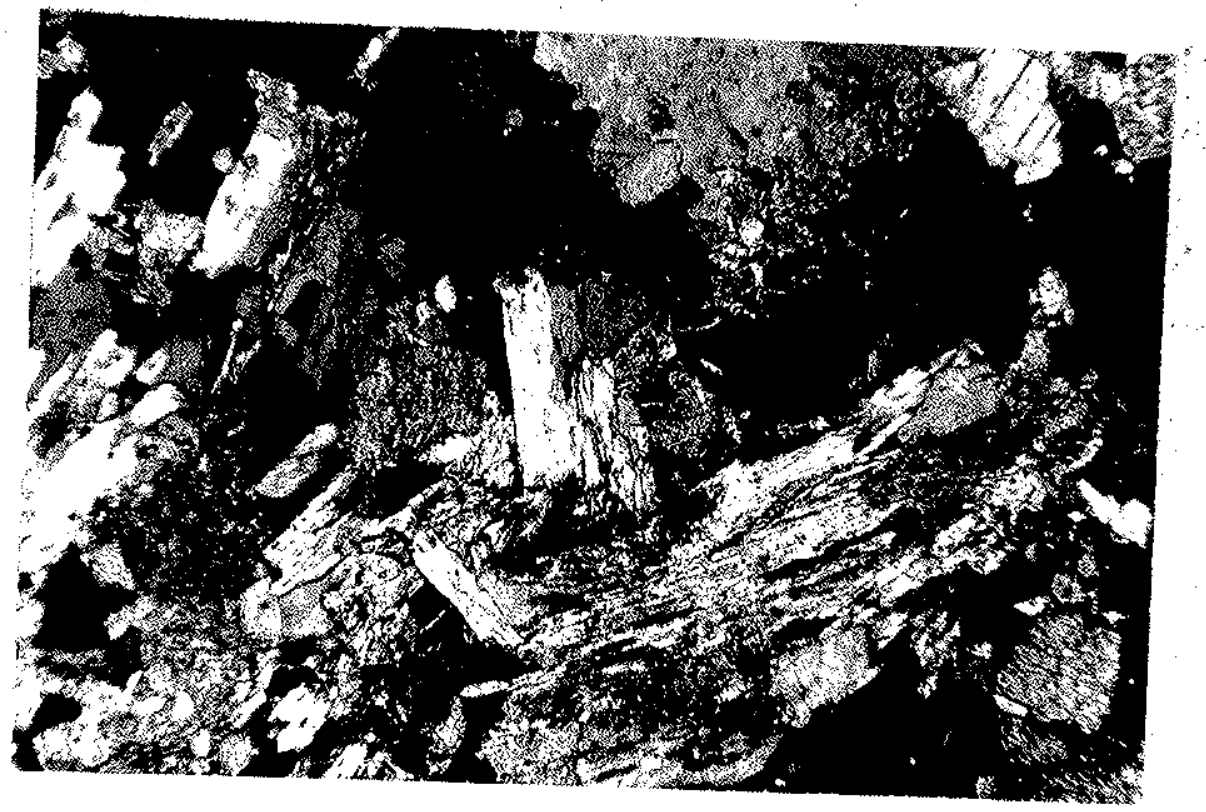

Fotomicrografia - $60 \mathrm{x}$, nicöis cruzados AMOSTRA NO 10 - CAJCÄRIO DO RIO GRANDE DO SUL

Rocha compacta, homogênea, não orjentada, granulação fina, cor cinza claro. A rocha em blocos apresenta algumas fraturas normalmente soldadas pelo pröprio carbonato. A anälise quimica expedita pelo aparelho de Chittick mosirou $81 \%$ de carbonato e $19 \%$ de resíauo insolivel.

A textura è grancblāstuica. Com uxcessão do anfibölio que se apresenta normalmente idioblästico, alongädo, os outros minerais: são xenoblästicos.

Os minerais constituintes são:

\begin{tabular}{|c|c|}
\hline Calcita & - \\
\hline Dolomita & - \\
\hline Tremolita-actinolita & - \\
\hline
\end{tabular}

A granulação média está em torno de $0,15 \mathrm{~mm}$, porëm ë bastan te variāvel na rocha, alcançando até $2 \mathrm{~mm}$. 


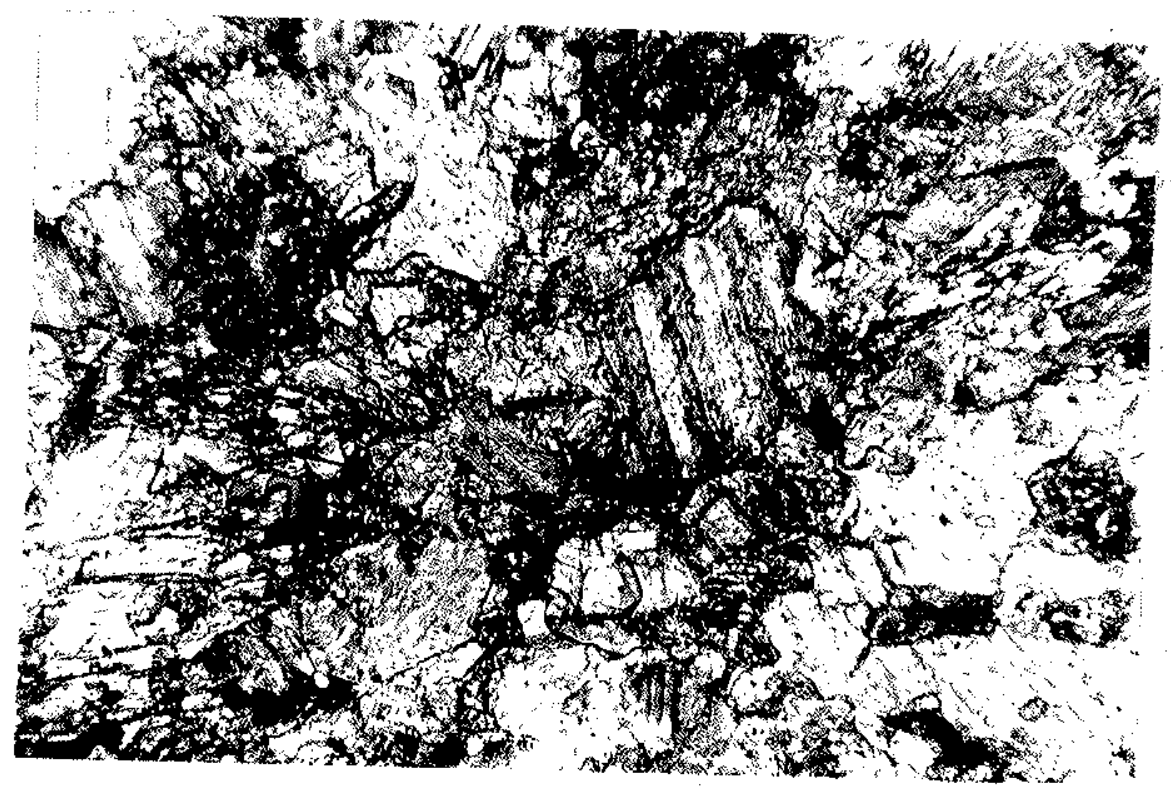

\section{Fotomicrografia - $170 \mathrm{x}$, nicöss cruzados AMOSTRA NO 11 - CALCARIO APIAI}

Rocha compacta, bastante homogenea, não orientada, granulaÇão fina, cor cinza médio. Os blocos de rocha apresentam fraturas soldadas por calcário mais claro, em distribuição irregular por toda a rocha.

A textura é granoblästica, equigranular, a granulação média estando próxima a 0,12 - 0,15 mm.

A anälise quimica expedita por neio do aparelho

de Chittick forneceu $56 \%$ de calcita e 8: de dolonita. O resicilo in solüvel (36\%) é constituído de: quartzo, tremolita-actinolita, muscovita e biotita e minerais opacos (pouco). Destes, apenas 'o quartzo è xenoblästico, sendo os outros minerais normalmente idioblästicos. 


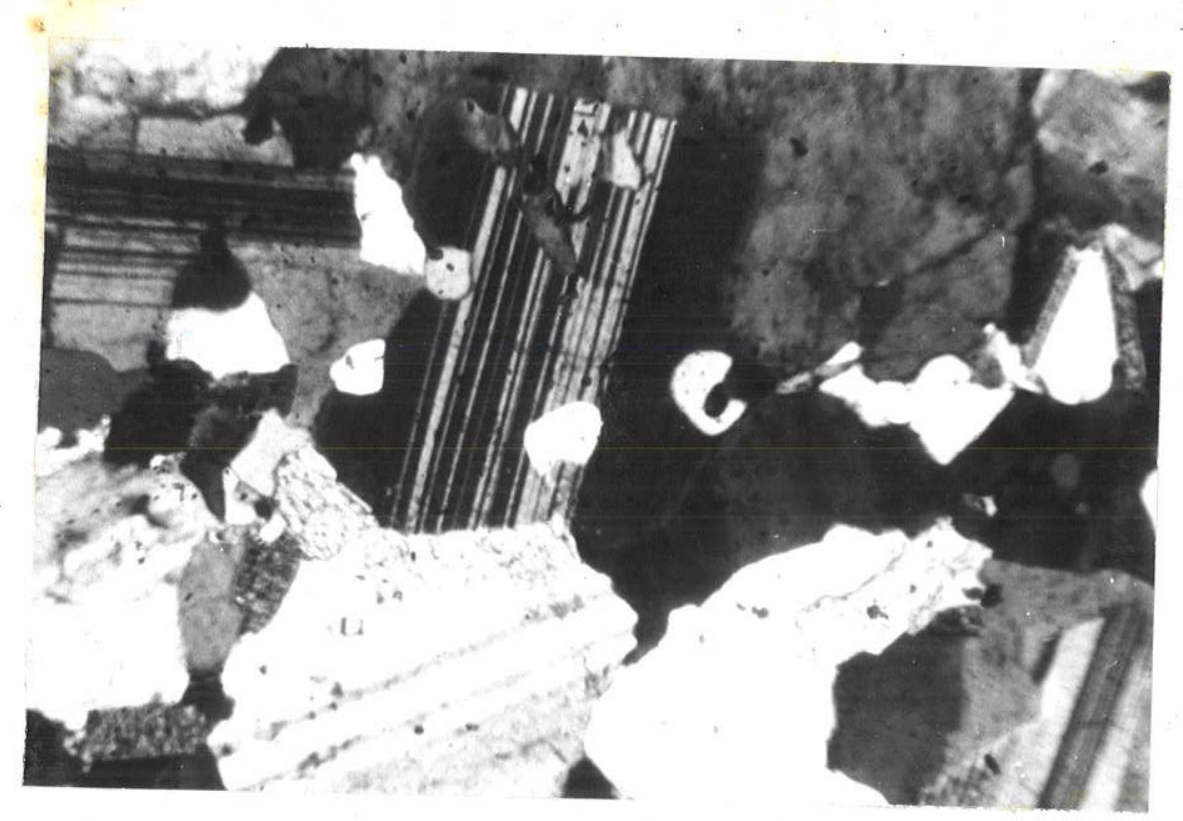

Fotomicrografia - $60 \mathrm{x}$, nicöis semi-cruzados AMOSTRA NO 12 - GRANITO SÃO DA ANHANGUERA

Rocha granitóide, compacta, faneritica, leucocrätica de cor cinza claro. A grande maioria da rocha ë equigranular, porëm apresenta alguns poucos cristais maiores de feldspato alcançancio 2-3cm. No campo, observam-se cavidades miaroliticas completamente preenchidas. Macroscopicamente apresenta uma pequena orientação, mal desenvolvida evidenciada pelos minerais micáceos. Os mi nerais principais são:

Plagioclásio (oligoclásio A An 20-30) 40\%

Feldspato potássico (pertita) 20\%

Quartzo 15-20\%

Muscovita (e alguma biotita) 5-10\%

Clorita, granada, zircão, epídoto, apatita - traços

A textura é do tipo hipidiomórfica granular. A granulação é média, a maior parte dos grãos entre 1,2 e 1,5 mm. O plagioclä sio domina sobre o feldspato potássico, situando a rocha como "Adamelito" ou mesmo "Granodiorito".

A altexação da rocha é incipiente, notando-se apenas descoloração da biotita; ocorre a].guma sericitização ou caulinização de feldspato e alteração hidrotermal ou deutērica fraca, formando clorita e epidoto. 


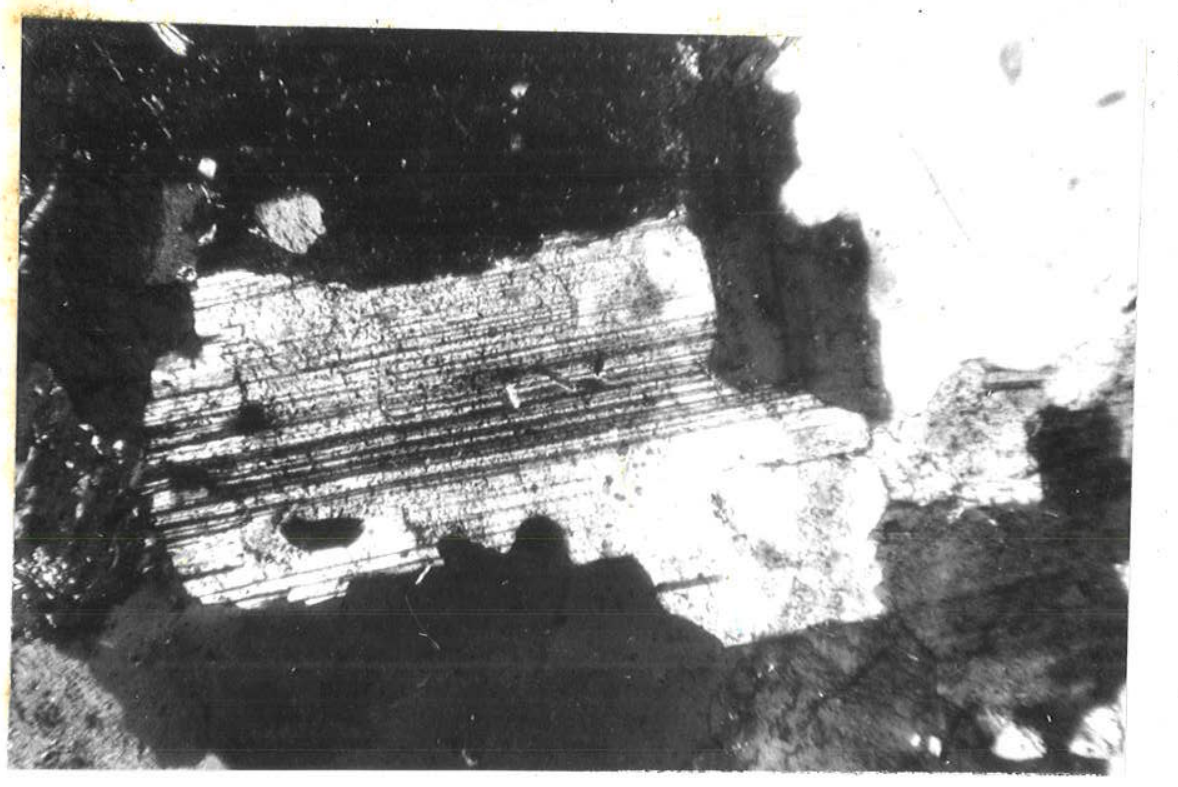

Fotomicrograíia - $50 \mathrm{x}$, nicōis semi-cruzados AMOSTRA NO 13 - GRANITO ALTERADO DA ANHANGUERA

O granito da pedreira Arhanguerá mais alterado (amostras mais superficiais) apresenta cor creme amarelado.

A alteração caracteriza-se for uma argilização mais acentua da dos feldspatos $\epsilon$ a coloração é devida aos óxidos de ferro em pequena quantidade. A biotita apresenta-se mais descolorida. 


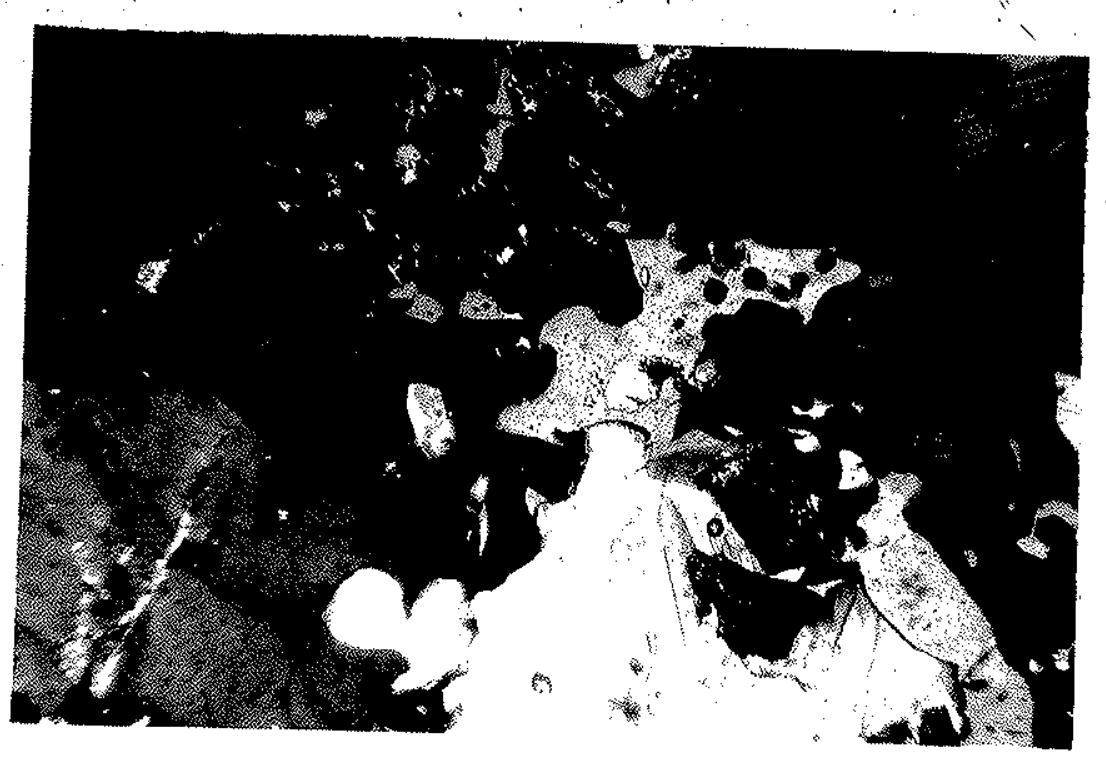

Fotomicrugrafía - 60 x, nicöis semi-cruzados

AMOSTRA NO 14 - CHAKNOCKITO DE UBATUBA

Rocha faneritica, de granulação grossa, leucocrätica, cor cinza esverdeado, aparertemente näo orientada. Apresenta numerosas fiaturas e fissuras, perceptirej.s macroscopicamente mesmo à escala dos cristais.

A textura é duvidosa, gmanobiästica ou granitica (nipidio múrfica granular: A granulação ê variāvel alcançando os feluspa tos dimensão centimëtrica. Os minerais constituintes são: feldapato potässico pertitico: plagioclásio sódico-cálcico loligoclá sio): quartzo e intercrescimento grärico, biotita e acessórios (hornblenda è anfibólios, hiperstênio - bronzita, mineral opaco, apatita e zircĩu) .

A rocha apresenta alteração mineralögica apenas incipiente, caracterizando-se por pequena liberaçãc de öxidos de ferro dos minerais ferromagiesiaros e alteração deutérica ou hidrotermal, caracterizada pela'formação de anfibólios fibrosos a partir de piroxênios. 


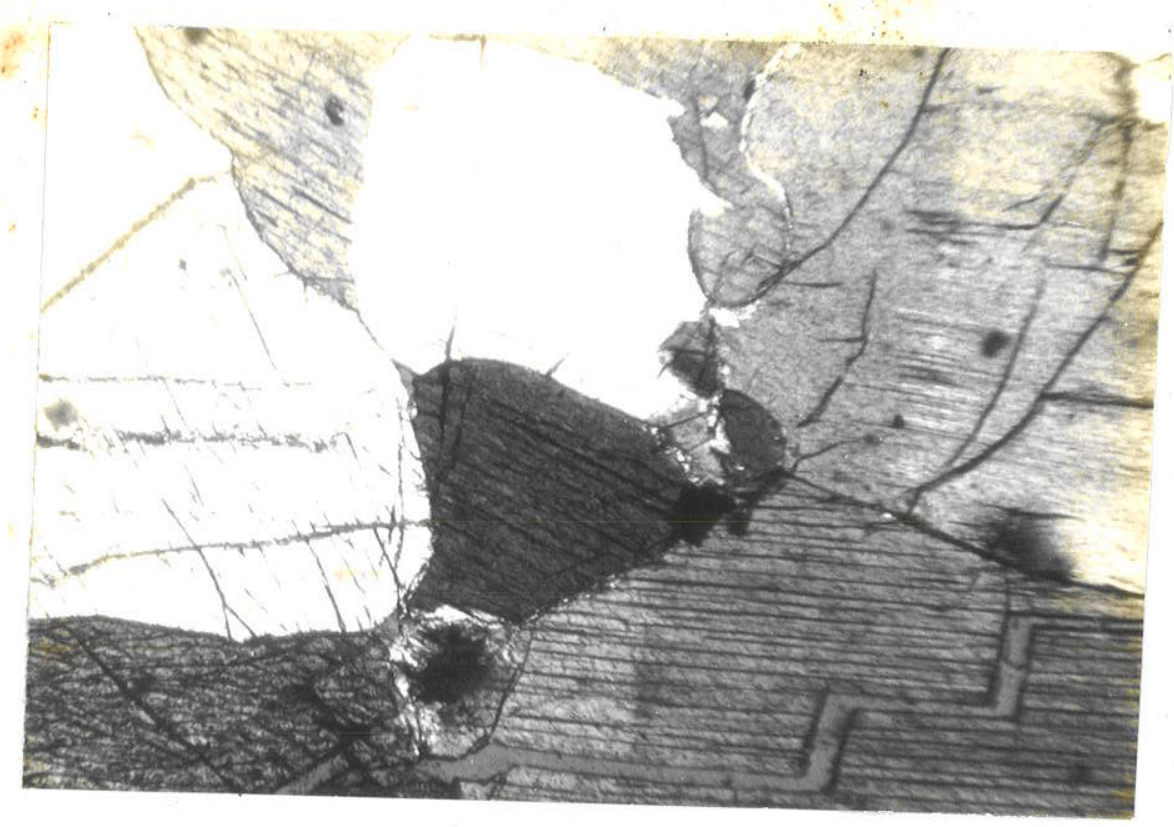

Eotomicrografia - 60, nicóis semi-cruzados AMOSTRA 15 - PIROXENITO DE NIQUELÂNDIA

Rocha compacta, homogênea, não orientada, granuiaçãu dia, fanerítica, melanocrātica, cor esverdeado claro. A amostra estudada apresenta manchas de óxidos de ferro avermelhadas e escuras, de distribuição irregular algumas vezes localizadas em fra
turas irregulares.

A textura é holocristalina, hipidiomórfica granular. A granuỉação é variável, a média dos grãos estando próxima a $2 \mathrm{~mm}$.

Os mirerais ccnstituintes são: ortopiroxênio (hiperstênio), clinopiroxênio (provavelmente augita ou diopsiaio) e mineral opa
co.

Os dois piroxênios ocorrem em proporções equivalentes (Websterito ?).

A rocha apresenta-se pouco alterada, caracterizando-se a al teração pela liberação de öxidos de ferro. 


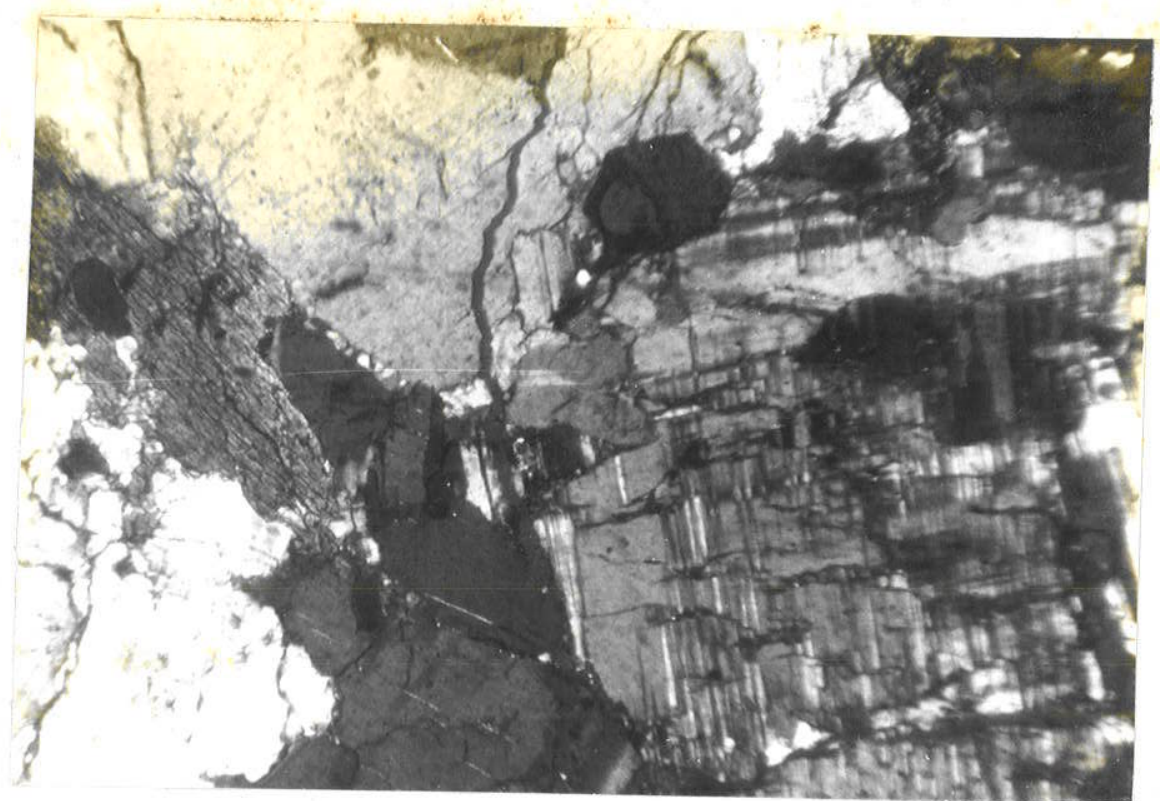

Eotomicrografia - $60 \mathrm{x}$, nicóis semi-cruzados AMOSTRA NO 16 - GRANITO DE SACOS

Granito gnāissico, compacto, de granulação mëdia, cor ró-sea, com gnaissificação pouco desenvolvida, dada por minerais ferromagnesianos. As amostras estudadas não apresentam fraturas desenvolvidas mas apenas fissuras na escala dos cristais.

A textura é granoblāstica, fracamente lepidoblāstica. Os cristais são inequigranulares, estando a granulação média em tor no de 1,0 - 1,2 mm.

Os minerais constituintes são:

Microclinio pertítico 50-60\%

Plagioclásio sódico ? $5-10 \%$

Quartzo

ح 15-20\%

Hornblenda

$\sim 10-15 \%$

Biotita

$\sim 5 \%$

Titanita

$\sim 2 \%$

Apatita e opacos - traços

A rocha se apresenta com alteração incipiente ou praticamen te $s \tilde{a}$. 


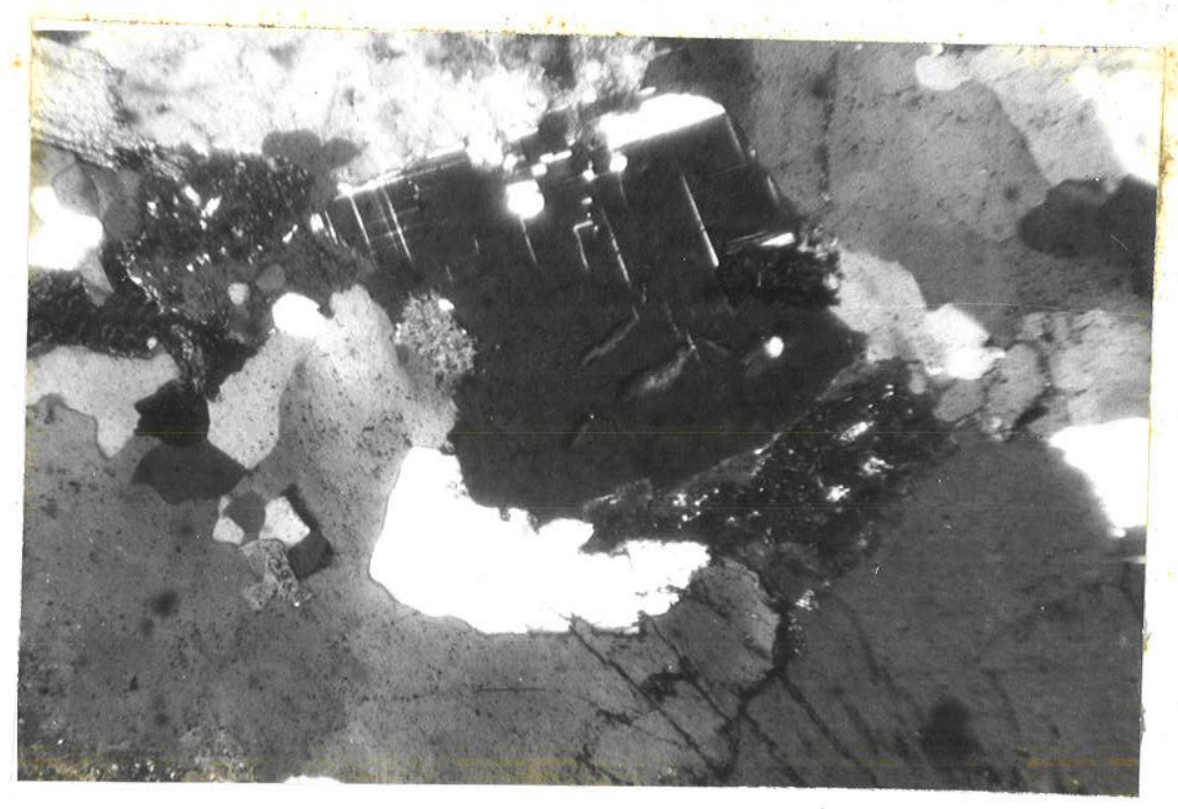

Fotomicrografia - $60 \mathrm{x}$, nicóis cruzados AMOSTRA NO 17 - MIGMATITO DE JABORANDI

Rocha gnáissica de composição adamelitica, estrutura em ban das normalmente mal definidas e nebuliticas. A rouha apresentase compacta, com granulação média a fina, e cor cinza mëdio. As vezes distinguem-se faixas mais claras, mais pohres em minerais ferromagnesianos.

A textura é granoblästicá, normalmente xenoblästica, com ex cessão da biotitu que algumas vezes è idioblástica. A granulação é um pouco variárvel, estando a média dos gräos próximo a 0,6 $0,7 \mathrm{~mm}$.

As amostras estudadas não apresentavam fraturas macroscopicamente reconhecíveis.

Os minerais constituintes são: micrcclinio pertitico (mui tas vezes zonado), pllagioclāsio sódico - cálcio (cligocläsio ?), quartzc, biotita, minerais opacos, apatita e zircão.

o microclinnio e o plagioclásio ocorrem em proporções equiva lentes. o plagioclásio apresenta-se parcialmente alterado em sericita, material argiloso e algum epidoto. o faldspato potássico apresenta-se são. A rocha no seu conjunto apresenta-se pratica mente sã. 


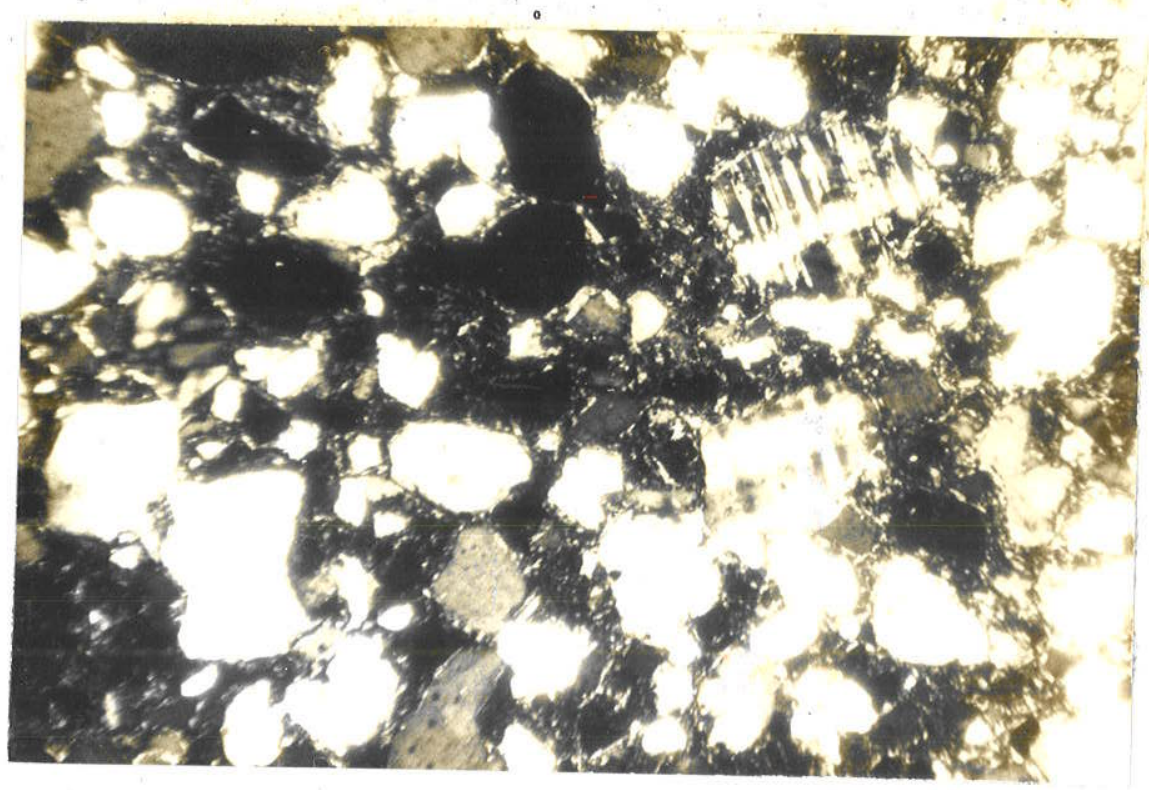

Fotomicrogratia - $60 \mathrm{x}$, nicöis cruzados

AMOSTRA NO 18 - ARENTTO BAURU

Rocha mal estratificada, bascante porosa e friävel, de cor creme acastanhacio. E constituida predominantemente (80-90\%) de grãos de quartzo subarredondados a subangulosos, normalmente iso diamétricos, com boa selef̧ão grarulométrica e diâmetro médio prô yimo a 0,25 rm. Observam-se ainda: microclírijo (pouco alterado), epídoto, muscovita; turmalina e mineral opaco.

A matriz da rocha é de natureza argilosa (sericita-ilita), associada a óxidos de $\vec{F}$. Coorre ainda uma pequena quantidade de cimento calcífero. 


\section{APENDICF B}

METODOS DE ENSAIOS PROPOSTOS

ENSAIOS MECANICOS E DE DURABIIIDADE 
$. M-1$

METODO NÃO DESTRUTIVO PARA DETERMINACR̃O DA RESTSTENCIA E ESTADO DE ALIERAC ÃO DE ROCHAS

\section{1. - OBJETTVO}

Este mëtodo tem por finalidade definir um sistema de medi. das, que possibilite a aplicação do esclerömetro schmidt na ava liação da resistêncja mecônica e estado de alteração de rochas, tarto no campo como em labosatörio.

\section{2. - $A P A R E L H A G E M$.}

Os equipamentos necessários consistem basicamente no seguin te:

2.1 - Esclerômetro schmidt com energì de percussão

$0,225 \mathrm{kgm}$, conformie figura em anexo.

2.2 - Suporte de corpos de prova err aço ou ferro fundido, com nlacas e varatusos de fixação reguláveis e dotado de haste guia para manter o esclerômetxo na vericical.

2.3 - Bigorna de calibração com inaice escleromētrico conhe cido.

2.4 - Estufa vertilada capaz de manter uma temperatura de $105^{\circ} \mathrm{C}$ (ou $70^{\circ} \mathrm{C}$ ) com uma variação definida cara um período de pelo menos 10 horas.

\section{3. - PREPARACÃO DAS AMOSTRAS}

\section{1 - Laboratöxio}

Os corpos de prova para ensaio em laboratôrio deverão ser prismáticos com palo menos uma dimensão de $10 \mathrm{~cm}$ ou ci Ifndricos de $10 \mathrm{~cm}$ de comprimento. A faces de ensaio, deverão permitir pelo menos 10 leituras em pontos com espaçamen to minimo de 1 cin. O no mínimo inicial de corpos de prova nestas condiçöes, deverá ser de 6 em perfeitas condições, is. to $\bar{e}$, com faces planas, horlzontais e sem trincas nem imper feições. Para os ensaios de ạ̣teração, o no de corpos de 
prova necessarios sera: o ho de ensaios a serem efetuados durante e upós alteração vẹes 3 e soma-se 3 .

\section{$3.2-$ Campo}

Delimita-se inicialmente âreas em paredes rochosas, de tal modo que abranja una superficie unjerme quanto à natureza petrogräfica. Se a superfície for relativamente unifor me: a área escolhida poderā ter aproximadamente $1 \mathrm{~m}^{2}$, e dividida na vertical em 2 partes: $A$ e B. Na parte A, demarcam se tantas linhas parale las verticais, espaçadas de no minimo $2 \mathrm{~cm}$, quatos forem os meses dis observaça a a serem efe tuajos. A seguix, em cada uma destas Ijrhas Locammse no minimo 30 ponto: distribuidos conforme a regularidade da. su perfïcie (espaçamento mínimo de $2 \mathrm{~cm}$ ). Na outra retede da

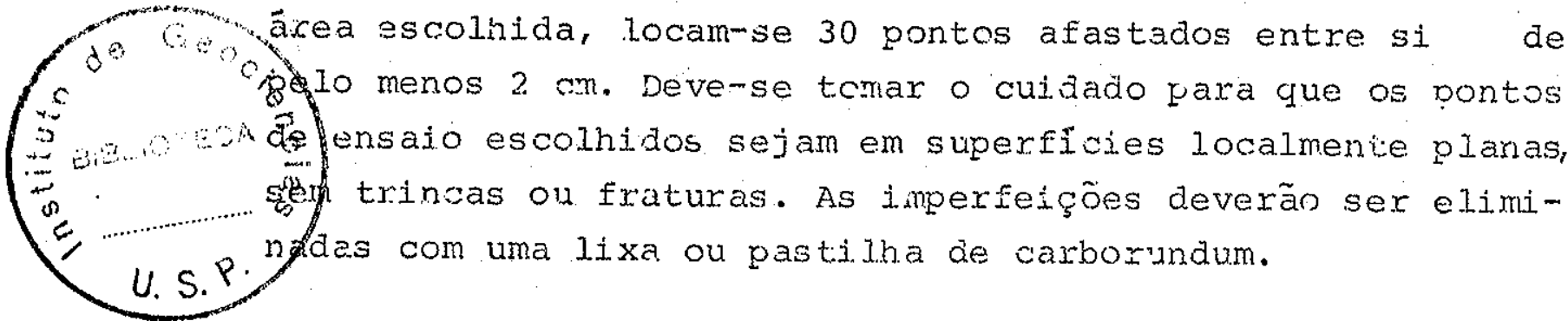

\section{4. - PROCEDIMENIO}

Apös a seleção de anostras de rocha, nas quais emprecaremos o esclerômetro, o instrumento é removido de seu escojo e a pon teira de impacto É des locada de sua posição fixa e ajustada contra a superfície da rocha, o esclexômetro é colocado perpencícum larmente à superficie, no ponto de ensaio e a ponteira é comprimida pela aplicação građural de pressão até zeu impacto. A seguir. pressiona-se o botäo da trava e anota-se a leitura na escała lateral do instrumento. Este botäo nunca deve ser pressionado du .. rante a quela dä ponteira.

Uma leve pressão sobre a ponteira deverä destravámla e,quan do inteiramente distendida, o instrumento está automaticamente preparado para o ensaio seguinte.

o sisterna de tomada de leituras é variável conforme o en saio seja executado no camoo ou laboratörio:

\section{1 - Laboratōrio}

Em 3 curpos de prova, nas condições do item 3.1. e ete 
tuam-se 30 leituras. Nos demais 3 corpos de prova, execu tam-se diversas leituras em 30 pontos, até que haja uma estabilização nos valores obtidos. Caso isto não ocorra, exe cutam-se no máximo 30 leituras.

paxa os ensaios de alteração, para cada determinado nümero de ciclos procede-se analogamente.

\section{2 - Campo}

Inicialmente, efetua-se uma leitura em cada ponto ca primeira linha vertical, da parte $A$, perfazendo urn total de 30 leituras. Na parte $B$, efetua-se diversas leituras em ca da um dos 30 pontos, até que haja uma estabilização nos vá lores obtidos. Procede-se analogamente nos meses subsequertes, somente que, na parte $A$, passa-se para as linhas conse cutivas seguintes, de tal forma que nunca ocorra uma repeti ção de ensaics num mesmo ponto.

\section{5. - CÁLCULOO DOS RESULTADOS}

Apös a realização das leituras atravës dos procedimentos descritos, comparamise os resuitados, calculando-se as mécias dispersões. O procedimento que apresentar o menor coeficiente de variação deverá ser o mäis adequado. Para o cálculo da média no caso do procedimento de impactos repetidos em um mesrio ponto, adotamse o último resultado ou a média dos ültimos, como valof do indice esclerométrico, quando ocorrer estabilizaçäo nas leitu ras. Caso isto não aconteça, até um máximo de 30 leicuras, o re sultado para aquele ponto deverä ser abancionado. Considera-se uma estabilização de leituras, quando ocorrer uma repeticiaade .. de valores seguidos, ou intercalados com uma diferença mäima de 15 음

Para avaliação da resistēncía mecânica antes e após alteração, transportam-se os resultados do melhor procedimento para os äbacos obtidos por Deere e Niller, que acompanham o instrumento, desde que seja conhecida a massa específica seca aparente da ro cha ensaiada (antes e após alteração) .

A seguir, aciota-se o procedimento descrito para cälculo da queda percentual de resistencia mecânica e coeficiente de altera 
bilidade, aos ensaios de alteração.

\section{6. - RELATORIO}

o relatório deverá incluir os seguintes dacios:

6.1 - Dimensões dos corpos de prova ou esquema da área da parede com os pontos locados.

6.2 - Mëdia e dispersöes obtidas para cada procedimento.

6.3 - mabela de observações periódicas.

6.4 - Estimativa da resistência mecânica apōs cada série de ensaios.

6.5 - Queda percentual de resistência e o coeficiente de al terabjlidade especifica.

6.6 - observações macroscöpicas sobre o estado de alteraçäo apös ensaio.

6.7 - Consideraçöes a respejto do mëtodo e curabilirade da rocha.

\section{7. - OBSERVACÕES}

7.1 - As superfícies de paredes rochosas deverãc ser previa mente limpas con escovas antes de cada ensaio.

7.2 - Para os ensaios de al teração en laboratörio, utilizase o procedimento descrito nos mätoäus de alteração, com os coxpos de prova obtidos.

7.4 - Caso se disponha de amostras, poderä ser tentada luma correlação dos, Indices escleromëtricos com os indices de compressão puntiforme.

7.5 - Em laboratório, aconselha-se utilizar o ensaio de alteração com o extrator soxhlet. Os demais ensaios de altera ção, poderão destruir muito rapidamente cs corpos de prova. confeccionados.

7.6 - Em rochas de estrutura vesicular, os pontos de ensaio não deverão estar sobre as vesiculas. 
7.7 - Modificações no ponto de ensaio como trincamento ou lascamento farão com que este ponto seja abandonado, computando-se até o penúlimo valor obtido. 


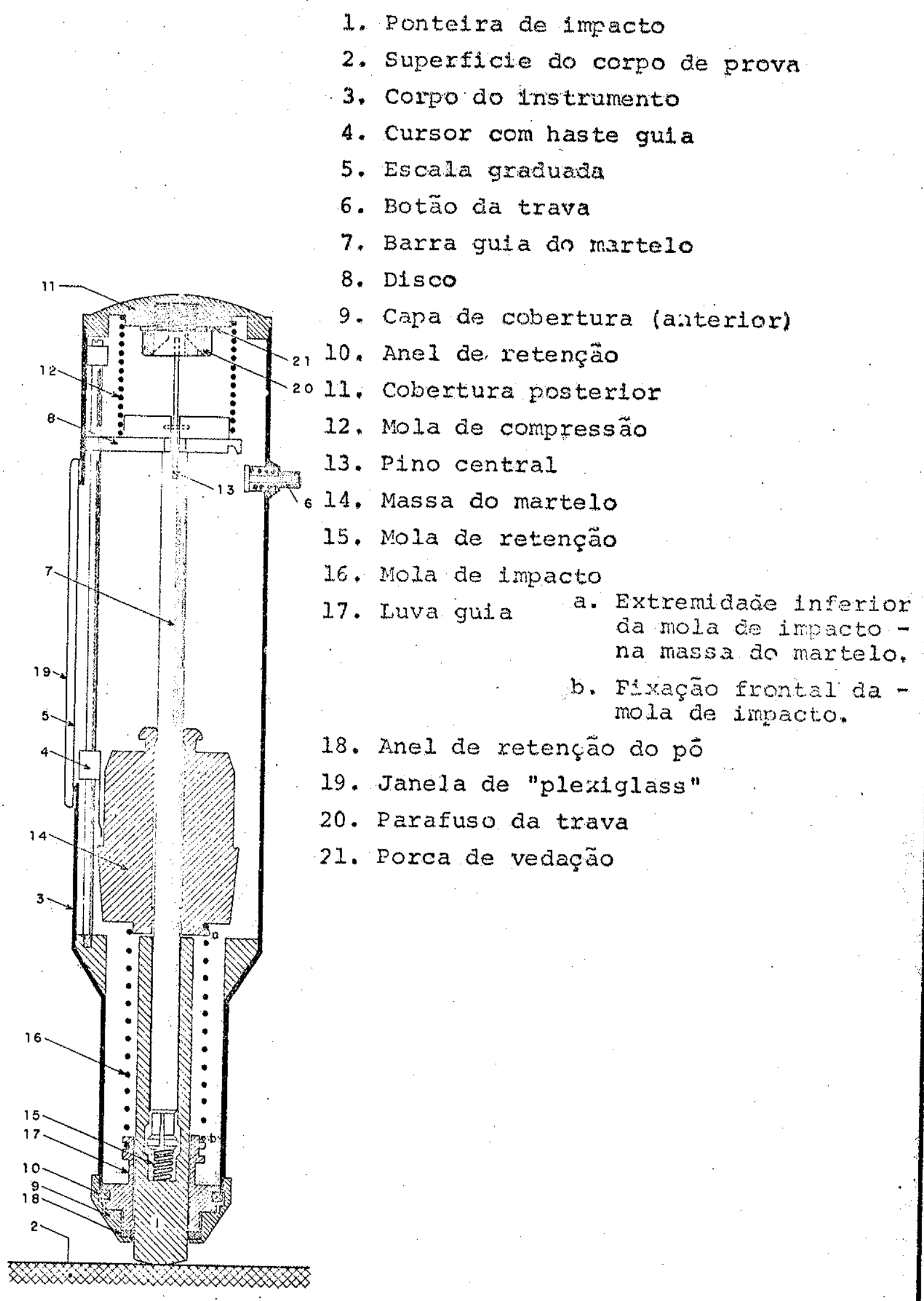




\section{I. - OBJETIVO}

Este mêtodo tem por finalidade determinar a resistência que uma rocha oferece ao impacto de um peso que cai de uma certa al tura. Vem expresso pela sltura de queda de um peso padrão para fraturar o coxpo de prova.

\section{2. - APARELHAGEM}

2.1 - Qualquer equipamento de impacto pode ser usado desde que possua (figura em anexo):

a) Uma base de concreto pesando não menos de $50 \mathrm{~kg}$, Fimemente fixada sobre funăação sólida.

b) ITm peso de $2 \mathrm{~kg}$ que caia livremente entre guias.

c) Un êmbolo de aço duro: pesarido $1 \mathrm{~kg}$ arranjado de tal modo que desize verticalmente, livremente, sendo sua parte inferior esferica convexa de raio i $\mathrm{cm}$.

d) Métos para elevar o peso e deixă-lo cair sobre c êrnolo de uma altura especificada desde l até não monos de $75 \mathrm{~cm}$, e meios para medir a altura de queda até $1 \mathrm{~mm}$.

e) Meios para segurar o corpo de prova na bigorna sem 3uportes laterais rigidos e sob o êmbolo de maneira tal que os centros coincidam durante o ensaio e a parte superior do corpo de prova seja tangenie à parte mais baixa, esférica do ềnoolo.

2.2 - Serra parra corte de rochas com djscos de carborundum e perfuratriz de laboratörio com coroa diamantada de $2,5 \mathrm{~cm}$ de diämetro.

2.3 - Estufa ventilaca capaz de manter uma temperatura de $105^{\circ} \mathrm{C}$ (ou $70^{\circ} \mathrm{Cl}$, com uma variação definida para um período de pelo menos 10 horas. 


\section{3. - PROCEDIMENTO}

os corpos de prova deverão'ser cúbicos de 2,5 cm de aresta ou cilínaricos de $2,5 \mathrm{~cm}$ de altura e 2,4 a $2,5 \mathrm{~cm}$ de diametro, em no de 7, de eixos retos formando ângulo de $90^{\circ} \mathrm{com}$ as superfi. cies planas. Caso haja anjsotropia nitida (como planos de fraque za), deveräo ser preparados 7 corpos de prova com estes planos perpendiculares ao eixo e 7 paralelos ao mesmo. Se näo for evi. dente tal anisotropia, deverão ser preparados por torneamento ao acaso. Durante a preparação, deverão sex tomados cuidados para que os corpos de prove não sejam suometidos a tensöes indevidas, que causen trincas ou rupturas.

Após a preparação dos corpos de prova, estes deverão ser lavados e secos em estufa a $1.00-11.0^{\circ} \mathrm{C}$, durante aproximadamente 10 horas. A seguir, retiram-se os corpos de prova da estufa e deixa-se esfriar por aproximadamente 2 horas, quando estarão pre parados para ensaio.

colocado o corpo de prova sob o émbolo, deixa-se cair o peso sobre o êmbolo de $1 \mathrm{~cm}$ de altura. Acrescenta-se $1 \mathrm{~cm}$ em ca. da nova queda atë a ruptura do corpo de prova. A altura da queda que causa a ruptura será a resistencia do impacto da rocha.

para que se obtenha uma boa mëdia representativa (para 95\% de confiança), com um exro relativo inferior a $15 \%$, efetuamse en saios em 7 corpoe de prova e extrai-se a mëdia dos valores obtidos, quardo não houver planos de fraqueza.

\section{4. - RELATORIO}

o relatório deverá incluir os seguintes dados:

4.1 - Os valores encontrados e a média dos mesmos.

4.2 - Quando houver planos de fraqueza, relatar os valores para os ensaios efetuados paralela e perpencicularmente aos mesmos com as respectivas mëdias.

4.3 - Qualquer anomalia nos corpos de prova deve ser relata da, como por exemplo, fraturas, planos de xistosidade, etc. 


\section{5. - OBSERVACÕES}

5.1 - Os corpos de prova deverão ser bem acabados, com fa ces planas e paralelas, bem horizontais. O acabamento pode ser efetuado em politriz de disco com esmeril ou carborun dum 500 .

5.2 - Dada as dimensões reduzidas dos corpos de prova, as amostras deverão ser representativas da rocha estudada.

5.3 - Corpos de prova com irregularidades de confecção como trincas e lascas, devexão sex eliminados. 


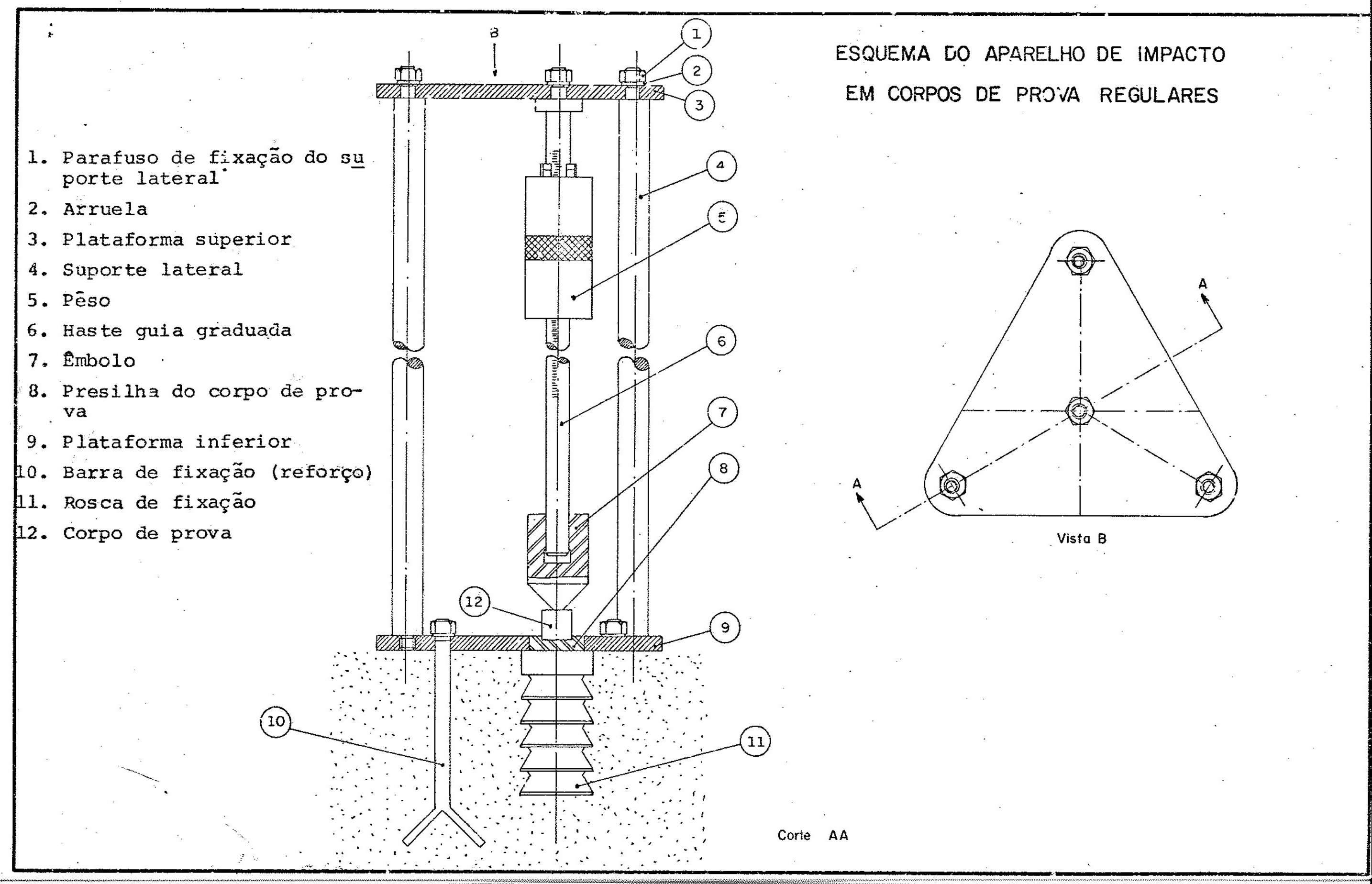




\section{1. - OBJETIVO}

Este ensaio é executado para indicar a resistência apresentada por uma amostra rochosa ao enfraquecimento e desintegração por atrito mütuo quando submetida a modifjcaçōes no conteúdo ae ăgua.

\section{2. - EQUIPAMENTOS NECESSARRIOS}

Os equipamentos necessários consistem basicamente no se guinte:

2.1 - Um tambor de ensaio cnde a geratriz é constituída por um cilindro crivado em uma malha de $2 \mathrm{~mm}$ de abertura, com uma base sólida fixa. Este tambor ë dotado de uma tampa só lida removível. Tanto o tambor quanto a tampa soliza removi vel é manufaturada em latão, que resiste a uma temperatura de $105^{\circ} \mathrm{C}$, é fácil de sex trabalhada e é suficientemente re sistente pasa não se deformar durante c uso. o tambor de ensaio deve ter $100 \mathrm{~mm}$ de comprimento e $140 \mathrm{~mm}$ de diâmetro. Deve-se tomar o cuidado para que a malha do cilindro esteja sempre desobstruida;

2.2 - Um recipiente de acrijico transparenta, para conter o tanbor de ansaio que é mortado de forma a permitir um vão livre de 40 mm entre o recipiente e a base da malha. O tambor é sustentado por um eixo horizontäl que repousa sobre mancais de ebonite e grafite que cobrem as calhas dos la dos do recipiente, permitindo uma rotação livre, o recipien te que deverá conter o líquido de hidratação até um nivel de $\pm 20 \mathrm{~mm}$ abaixo do eixo do tambor, tem as seguintes dimen sóes: $190 \mathrm{~min}$ de comprimento, $149 \mathrm{~mm}$ de largura e $120 \mathrm{~mm}$ de altura. 
2.3 - Um motor com redutor com as seguintes características:

a. Rotação dè saída do redutor: $20 \mathrm{rpm}$

b. Tensão: $1 \geq 0 \mathrm{~V}$

c. Motor de indução monofäsico, protegido contra pene tração de água.

d. Frequéncia da rede: $60 \cdot \mathrm{Hz}$

e. Torque: a $16 \mathrm{kgf} \mathrm{cm}$ (na saida do redutor 8 para cada 1 ado)

f. Sáda do eixo do redutor para os 2 lados.

Este dispositivo motorizado deverá ter a capacidade de yirar 2 ou 4 tambores a uma velocidade de 20 revoluçós por minuto, riantendo a velocidacie constante dentro de um pe riodo de lo ritinutos.

O equipamerto montado encontramse na fotografia, e no esquema, em anexo.

2.4 - Uma estufa ventilada capaz de manter uma temperatura cie $105^{\circ} \mathrm{C}\left(01 \mathrm{~d} 70^{\circ} \mathrm{C}\right)$ com uma vaxiação definicia para um perïom do de pelo menos 10 horas.

2.5 - Uma balança edequada para pesar o trambor mais a amostra com uma precisão de 0,5 a $1,0 \mathrm{~g}$.

\section{3. - PREPARO DO CORPO DE PROVA E IPROCEDTMEITO DE ENSAIO}

3.1. - Seleciona-se uma amostra representativa composta de 10 fragmentos, pesando entre $40.60 \mathrm{~g}$, para dar um peso total entre 450 a $550 \mathrm{~g}$. Os fragmentos devexĩo ser afeiçoados pa ra que tenham formas aproximadamente equidimensionais.

3.2 - A amostra é culocada em um tambor previamente limpo e é secacia até a constância de peso a uma temperatura de $105^{\circ} \mathrm{C}$ $\left(0 u 70^{\circ} \mathrm{C}\right)$, durante geralmente 5 a 10 horas na estufa.

3.3 - A seguir, registra-se o peso do tambor mais amostra: peso A.

3.4 - Recoloca-se a tampa e o tambor ë montado no recipiente e acoplado ao notor.

3.5 - Preanche-se o recipiente com un Iíguido de hidrataçäo 
até ur nivel de \pm 20 mm abaixo do aixo do tambor e a seguin gira-se o mesmo a 20 revoluções por minuto aurante un perío do de 10 mínutos.

3.6 - Remove-se o tambor do recipiente, retiramse a tampa do mesmo e este, mais a porção retida da amostxa são secados até um peso constante a $105^{\circ} \mathrm{C}$ (ou $70^{\circ} \mathrm{C}$ ).

3.7 - o peso do tambor mais a porçäo retida da amostra é registrado (B).

3.8 - Registra-se por rim, o peso c do tambor limpo e seco.

\section{4. - CAMCULOS}

- Iradice de aurabijiłade à hidratação é calculado como a relação percentual entre os pesos secos inicial e firial de uma amostra rochosa submetida a ciclos padronizados de secagem e une decimento.

Indive de desgaste a ümido

(Indice de curabilidade à hidratação)

$$
I d=\frac{B-C}{A-C} \times 1.00 \%
$$

onde:

$A=$ peso do tambor $t$ amostra seca antes do ensaio (em g).

$B=$ peso do tambor + amostra seci reticia (em g).

$C=$ peso do tambor limpo e seco (em g).

\section{5. - ELABORACCÃO DO REIATORIO}

Para cada ensaio realizado, deverão constar as seguintes in formações :

5.1 - o indice de desgaste a ümido, com precisão de l\%

5.2 - A natureźa do İ́quido de hj.dratação

5.3 - Observações sobre os frammentos retidos e sobre o material passante na malha do tambor.

\section{6. - NOTZS}

6. 1 - Os ensaios poderão ser executados com 1 ou mais tambo

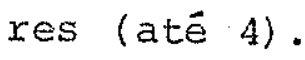


6.2 - Amostras de rochas sãs poderão ser previamente submetidas a ciclos de alteração artificial (Soxhlet, etilenogli col, äguamestura), tendo-se o cuidado de se conhecer os vam lores de desgaste a ümido, antes de qualquer ciclagem.

6.3 - O ensaio poderá ser executado com outros líquidos de hidratação além da ägua, como por exemplo, āgua desti.lada,ãgua salgada, ägua com ácidos diluídos ou pode-se empregar agentes expansivos como o etileno-glicol ou ägua oxigenada (30 volumes).

6.4 - Materiais que apresentam grande desagregação, a fra ção passante na nalha do tambor poderia ser submetida aos ensaios de classificação de solos (p. ex., ensaio de expansão em pastilhas). 


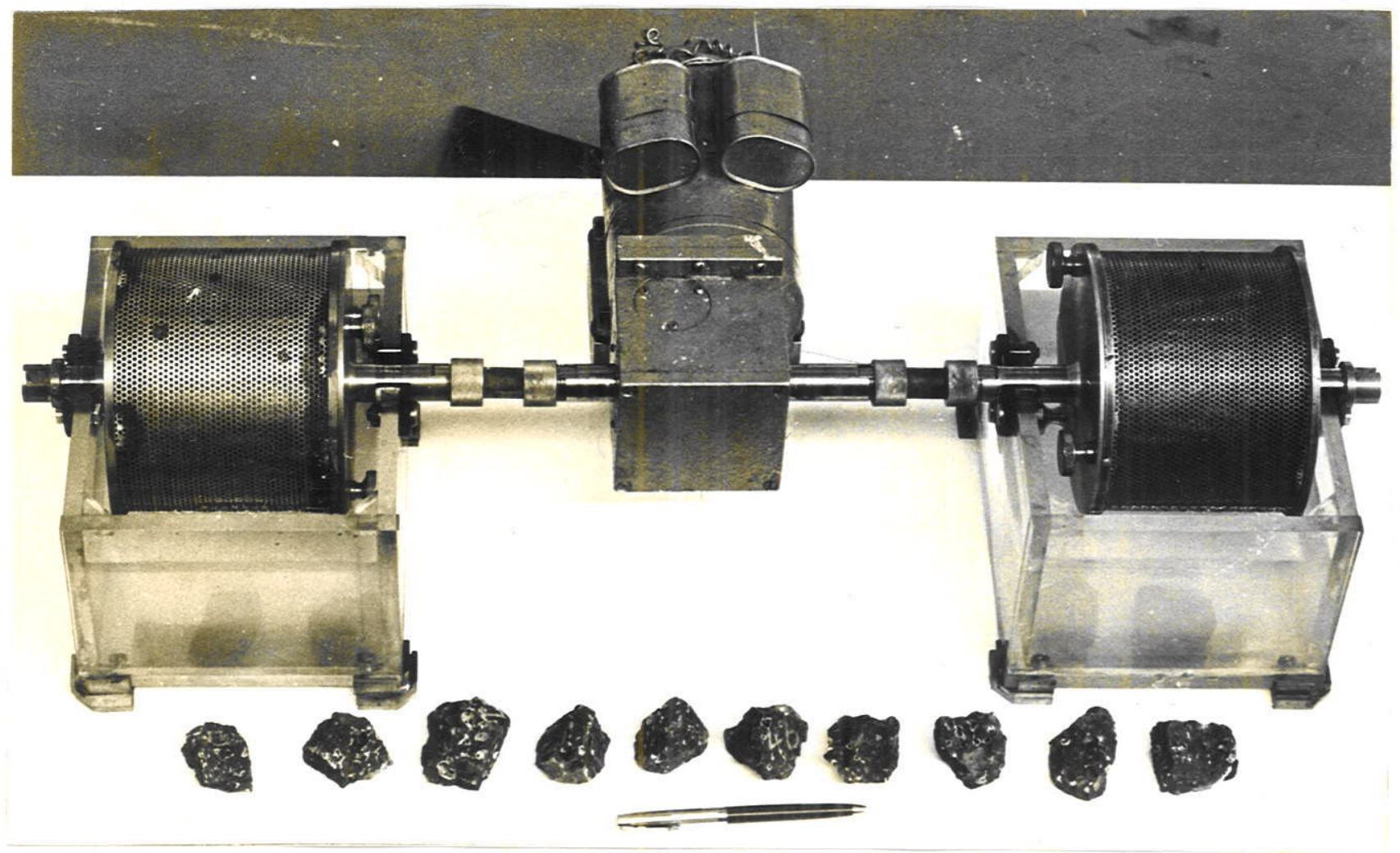

Equipamento para determinação do Indice de desgaste a úmido

1 - Tambor de ensaic confeccionado em latão. Dimensões: $100 \mathrm{~mm}$ de com priinento e $140 \mathrm{~mm}$ de ai âmetro.

2 - Recipiente de acrílico transparente

3 - Motor e redutor com duas saidas laterais

4 - 2uantidade de amostra para ensaio de cada tanbor

5 - Calhas dos recipientes de acrílico reforçadas com inancais de ebcnite e grafite. 


\section{1. - OBJETIVO}

Este mëtodo tem por finalidade determinar a resistência à alteração de rochas, submetidas a uma lixiviação contínua em. ex trator soxhlet, que reproduz razoavelnente bem, determinadas con dições da iatureza. Este mëtodo permite tambēm uma previsão da queda de resistência mecânjca, principalmente de agregados susce tîveis à ação química da ägua.

\section{2. - APARELHAGEM}

A aparelhagem necessäria constitui bàsicamente no seguinte: 2.1 - Uma estufa ventilada capaz de manter uma temperatura de 105 a $110^{\circ} \mathrm{C}$ (ou $60-70^{\circ} \mathrm{C}$ ), com una variação definida para um período de pelo menos 10 horas.

2.2 - Para pesar o agregado miúdo ou pequenas quantidades de agregado graúdo, uma balança com capaciade de no mínimo $500 \mathrm{~g}$ e sensibilidade de $0,1 \mathrm{~g}$, e para o graúdo uma balança com capaciclade de no mínimo $5000 \mathrm{~g}$ e sensitilidade de $1 \mathrm{~g}$. 2.3 - Bandejas metälicas de folhas de dimensões adequadas,para secagem dos materiais na estufa.

2.4 - Manta aquecedora com regulador de voitagem.

2.5 - Extrator Soxhlet de sifão baixo, conforme a figura do anexo II.

2.6 - Peneiras de malhas quadradas com caixilhos metalicos de $203,2 \mathrm{~mm}$ de diâmetro, $50 \mathrm{~mm}$ de altura, de acordo com a especificação ASTM: El.l-39, de aberturas nominais respectivamerte de 19,1 a $15,9 \mathrm{~mm}$ e 1,68 mm para o ensaio de impacto Treton, de $19,1 \mathrm{~mm}$ a $9,46 \mathrm{~mm}$ e $1,68 \mathrm{~mm}$ para o ensaio de abrasão Los Angeles, de 38,1 mm a 25,4 min para o ensaio de desgaste a umido. 
2.7 - Aparelho rreton, do padräo DER: P81-52T.

2.8 - Mäquina de abrasão Los Angeles, conforme MB-170 do DER.

2.9 - Aparelho de desgaste a úmido, conforme descrito na pesquisa EPC-7 e Ilustrado no anexo $I$.

\section{3. - PPEPARZCẼO DAS AMOSTRAS}

Após a britagem, peneirar o material a ser ensaiado em fraçc̃es individuais conforme a sërie de peneiras mencionada.

lorna-se tantas amostras de cada fração cuantos forem os en saios mecânicos a serem executados, para um determinado no de ci clios. Desta maneira, o peso de cada fração deve concordar com o indicado a seguix, para um único ensaio mecânico a ser executado apōs um determinado no de ciclos. Os pesos de cada fração a ser ensaiada, deverão ser multiplicados por $2,3, \ldots, n$, se o no de ensaios mecânicos intermediários de controle for respectivamente $1,2, \ldots \ldots, n-1$.

Granulação

(mm)

38,1 a 25,4

19,1 × 15,9

19,1 a 12,7

12,7 a 9,5
Peso da amostra para ensaio

$(\mathrm{kg})$

1,2

1,5

5,0

5,0

Observa-se que as amostras obtidas devem ser bem lavadas e secas atë um peso constante.

\section{4. - PROCEDIMENTO}

Após lavagem e secagem em estufa a $100-110^{\circ} \mathrm{C}$ até atingir pê so constante, separa-se a amostra em diferentes frações conforme - item 2.6, por peneiramento. Pesam-se as quantidades nas dife rentes frações, que são colocadas separadamente dentro do extrator soxhlet, onde sofrerão um processo de lixiviação continua.

Um extrator Soxhlet (fig. ), consta essencialmente de um 
balão, tuoo extrator, e uma unidade de condensação. Un ciclo no extrator constitui-se basicamente no seguinte: a água evaporada no balão, graças a uma unjdacie de aquecimento controlävel (manta aquecedora com regulador de voltagem); condensa-se, precipita-se sobre a amostra e infiltra-se nos fragmentos. Quando a ägua atin ge o nivel do sifão, $\bar{e}$ sifonada de volta para o balão, recome çando o ciclo da ägua. No interior deste aparelho distingue-se 2 regiōes:

\section{A. Zona atmosferica}

Anostras nunca submexass, velocidade de percolação da água muito grande.

B. Zona de flutuação do nível da ägua

zimostras alternadamente imezsas e emersas.

Para que as condiçōes de alteração sejam aproximadamente uniformes, a quantidade de amostra nunca deverä ultrapassar a al tura do sifão, no tubo extrator.

Após cada $30 \mathrm{cjcjos}$ no extrator, retiráse uma das amostras de cada fração para medida de sua resistência mecänica. As de niais amostras deverão continiar até os pröximos ciclos requeri dos.

\section{5. - ANAAIISE QUANGITATIVA}

A anālise quantitativa è efetuada da seguinte forma:

A amostra retirada deve ser lavada e seca na estufa a 100$110^{\circ} \mathrm{C}$. Lurante o periodo de secagem, retiram-se as amostras dir estufa, esfriam-se à temperatura ambiente e pesan-se a interva Ios de 3 horas apös pejo menos 8 horas na estufa. Após ter sido atingido o peso constante, esfriam-se as amostras (por aproximadamente 3 horas), que são peneiradas durarte 5 minutos com a mes ma peneira na qual tinham sido retidas antes do ensaio. A seguir, pesa-se o material retido de cada frậão com a precisão ae $0,1 \mathrm{~g}$.

o naterial passante nas peneiras, constitui a perda en peso devido à ciclagem, correspcndente à parte mais desagregável, de resistência mecânica nuia. O material retido, pesado, das fra.ções consideradas, é ensaiado da seguinte forma: 
Granulação (mm)

19,1 a 15,9

19,1 a 12,7

12,7 a 9,5

38,1 a. 25,4
Ensaio

impacto Treton

abrasão Los Angeles

desgaste a úmido.
Método

IPT $\mathrm{M}-52$

$M B-170$

Descrito na pesquisa $\mathrm{EPC}-7$

o călculo da resistência mecânica final do material, para um determinado no de ciclos é efetuado ponderando-se as resistên cias mecânicas dos materiais passante e retido apōs a ciclagem, atravês da förmula:

$$
R . f=\frac{X \cdot R P+(100-X) R x}{100}
$$

onde:

$\mathrm{X}=\frac{\circ}{\mathrm{a}}$ de perda na ciclacern

$100-X=\%$ de material que resistiu à ciclagem

$R p=$ Resistência mecânica do material passante

Rr = Resistência mecânica do material retido

RI = Resistência mecânica final para um determinado no de cí clos.

Como $\mathrm{Rp}=0$, a fórmula acima fica reduzida a:

$$
R f=\frac{(100-X) R r}{100}
$$

A queda percentual da resistência mecânica inicial, vâlida para o intervalo de ciclos considerado, pode ser expressa como:

$$
\Delta R=\frac{R i-R \dot{E}}{R E} \cdot 100
$$

onde:

$\Delta \mathrm{R}=$ queđa percentual da resistência mecānica inical

Ri = Resistência mecânica inicial

Rf = Resistência mecânica final para um determinado no de ciclos.

A relaçăo entre a queda percentual de resistência mecânica e a resistência mecânica inicial fornece um índice que exprime a suscetibilidade de uma determinada rocha em sofrer uma queda na sua resistência mecãnica quando subrnetida a ciclos de lixiviação no extrator Soxhlet. Este indice è designado coeficiente de alte 
rabilidade específica $K$, obtido pela förmula:

$$
K=\frac{\Delta R}{R i}
$$

\section{6. - ANALISE QUALITATIVA}

A anälise qualitativa deverá constar de observações periódi cas sobre o aparecimento de fragmentos desagregados, trincados,fragmentados; modjficações na cor dos fragmentos; acompanhamerto fotogräfico e exame petrogräfico antes cio ensajo e após carla de terminado no de ciclos, caso se mostrem afetados. Somente frag mentos maiores que $3 / 8^{\prime \prime}(9,51 \mathrm{~mm})$, são adequados para esta anäl se.

\section{7. - REIATORIO}

O relatörio deve incluir os seguintes dados:

7.1 - Peso de cada fração de cada amostra antes do ensaio.

7.2 - Porcentagem de perda para cada peneiramento efetuado. A peneira usada na determinação da perda deverä ser a pró pria peneira da granulação do ensaio de alteraç̃o.

7.3 - Resistênuia mecânica do material retido apös cada determinado no de ciclos.

7.4 - Resistência mecânica final após cada determinado no de ciclos.

7.5 - A queda percentual de resistência mecânica e o ccericiente de alterabilidade específica.

7.6 - Fotografias de acompanhamento e anälise petrogräfica com fotomicrografias.

7.7 - Observaçōes rnacroscōpicas sobre o estado de alteração após ensaio.

7.8 - Se possivel, execução da difrutometria de raios $\mathrm{X}$ ar tes do ensaio e após, no pó formado pela alteração, para de terminação da natureza do produto e, principalmente das pro 
porçôes dos argilominerais presentes.

7.9 - Considerações a respeito da durabilidade da rocha.

\section{8. - OBSERVACÕES}

Utiliza-se diferentes tipos de ensaios mecânicos neste méto do, para verificar se:

A. Tanto a tenacidade como a resistência à abrasão, podem constitulr-se em parâmetros mecânicos do estado de alteração.

B. Como o cälculc dos valores nos ersaios necânicos citados segue a mesma diretriz: os inaices de alterabilidade deverão ser. aplicáveis para todos.

C. Conforme a quantidade de material disponivel, pode-se em pregax qualqier um äos parâmetros vitados. 
ENSAIO DE RESISTENCIA À ALTERACT̃O COM SATUPACÃO-SECAGEM E MEDIDA DO COMPORTAMENTO MECANICO DA ROCHA

\section{1. - OBJETIVO}

Este método tem por finalidade determinar a resistência alteração de rochas, submetidas a ciclos sucessivos de saturação em ăgua à temperatura ambiente e secagem em estufa a $100-110^{\circ} \mathrm{C}$. Este método permite também uma previsão da queda de resistência mecânica de agregados subretidos a condições particulares de uso, principalmente variações de temperatura e umidade.

\section{2. - APARELHAGEM}

A aparelhagem necessaria constitui basjcamente no seguinte: 2.1 - Uma estufa ventilada capar de manter uma temperatura de 105 a $110^{\circ} \mathrm{C}$ (ou $60-70^{\circ} \mathrm{C}$ ), com uma variaça definiaa para um periodo de pelo mersos 10 horas.

2.2 - Para pesar o agregado miúdo ou pequenas quantidadas de agregado graúdo, uma balionça com capacidade de no mínimo 500 y e senstbiljade de 0,1g,e para o qrắa uma balanģa com capacidade de no mínimo $5000 \mathrm{~g}$ e sensibilidade àe $1 \mathrm{~g}$. 2.3 - Bandejas metälicas de folhas de dimensões adequadas,. para secagem dos materiais na estufa.

2.4 - Tanques abertos para saturação das anostras em ägua.

2.5 - Penejras, de malhas, quadradas com caixilho metälico de $203,2 \mathrm{~mm}$ de diâmetro, $50 \mathrm{~mm}$ de altura, le accordo com a especificação ASTM: ElI-39, de aberturas nominais respectivamente de 19,1 $\mathrm{mm}$ a $15,9 \mathrm{~mm}$ e $1,68 \mathrm{~mm}$ para o ensaio de im pacto Treton, de $19,1 \mathrm{~mm}$ a $9,46 \mathrm{~mm}$ e 1,68 $\mathrm{mm}$ para o ensaio de desgazte a ümido.

2.6 - Aparelho Treton, do padrão DER: P81-52T.

2.7 - Máquina de abrasão Los Angeles, conforme MB-170 do DER. 
2.8 - Aparelho de desgaste a ümido, conforme descrito na pes quisa EPC-7 e ilustrado no anezo I.

\section{3. - PREPARACÃO DAS AMOSTRAS}

Após a britagem, peneirar o material a ser ensaiado em frações individuais conforme a sërie de peneiras mencionada.

Toma-se tantas amostras de cada fração quantos forem os en saios mecânicos intermediārios de controle a serem executados, pa ra um deterninado no de ciclos. Desta maneira, o peso de cada. fraça deve concordar com o inaicado a seguir, para um ünico en saio mecânjco a ser executado apös um determinado no de ciclos. Os pesos de cada fração a ser ensajada, deverão ser multiplica dos por $2,3, \ldots$, se o no de ensajos mecânicos irtermediarios de controle for respectivamente $1,2, \ldots, n-1$.

$\begin{array}{lc}\begin{array}{c}\text { Granulação } \\ (\mathrm{mm})\end{array} & \text { Peso da amostra para ensaio } \\ 38,1 \text { a } 25,4 & (\mathrm{~kg}) \\ 19,1 \text { a } 15,9 & 1,2 \\ 19,1 \text { a } 12,7 & 1,5 \\ 12,7 \text { a } 9,5 & 5,0 \\ \end{array}$

Observa-se que as amostras obtidas deven ser bem livadas $\epsilon$ secas até um peso constante.

\section{4. - PROCEDTMENTO}

Apös lavarem e secagem em estufa a 100-110 ${ }^{\circ} \mathrm{C}$, atë atingi: peso constante, separa-se a amostra en diferentes frações confor me o item 2.5, pox peneiramento. Pesam-se as quantidades nas di ferentes fraçóes, que são colocadas separađamente em bandejas identificadas e levadas à imersão, atê saturação completa em àgua por 16 horas.

Após o período de imersão, removem-se as amostras de agrega. do e levam-se à estufa a $100-110^{\circ} \mathrm{C}$ até que seja atingido um peso constante. Durante o periodo de secagem, retiram-se as amostras da estufa esfriam-se à temperatura ambiente e pesam-se a interva 
Ios de 3 horas apös pelo menos 8 horas na estufa. Após ter sido atingido o péso constante, esfriam-se as amostras (por aproximadamente 3 horas), à temperatua ambjente, quando estarão prepara das para nova imersão na ăgua.

Repete-se o processo de saturação e secagem alternada atẻ - que o no requexido de ciclos seja atingido.

\section{5. - ANALISE QUANTITATIVA}

A anälise quantitativa $\ddot{e}$ efetuada da seyuinte forma:

Após caủe 10 ou 20 ciclos, retiram se amostras para a medi da de sua resistêncira mecânica. para isto, as ser atingido o no ce viclos reguexido e apös resfriamerto, retira-se uma das amostras de cada fração. As demais amostras deverão continuar até o próximo no de ciclos requerido. A amostro retirada deve ser lava da e secada a $100-110^{\circ} \mathrm{C}$ e pereirada durante 5 minutos com a mes ma peneira na qual tirham sido retidas antes do ensaio. A seguir. pesa-se o material retido de cada fraçăo corn a precısão de 0,19 .

o material passante nas peneiras, constitui a perda em peso devicio a ciclagem, corxespondente à parte mais desagregável, de resistência mecârica nula. O material retido, pesado, das fra. ções consicieradas, è ensalado da seguinte forma:

$$
\begin{aligned}
& \text { Granulaç } \Xi \text { (mm) } \\
& \text { Ensaio } \\
& \text { Mëtodo } \\
& 19,2 \quad 3.15,9 \\
& \text { impacto ireton } \\
& \text { IPTM- } 52 \\
& 19,1 \text { a } 12,7 \\
& 12,7 \text { a } 9,5 \\
& \text { abrasão Los Angeles } \\
& M S-170 \\
& 38,1 \text { a } 25,4 \\
& \text { desgaste a úmicio }
\end{aligned}
$$

$$
R f=\frac{X \cdot R p+(100-x) R E}{100}
$$


- onde:

$X=\frac{o}{\partial}$ de perda na ciclagem

100-X $=8$ de material que resistiu à ciclagem

$R p=$ Resistência mecânica do material passante

$\mathrm{Rr}=$ Resistêncja mecânica do material retido

Rf = Resistência mecânica final para um determinado no de ciclos

Como $\mathrm{Rp}=0$, a förmula acima fica reduzida a:

$$
R E=\frac{(100-x) R r}{100}
$$

A queda percentual da resistência mecânica inicial, välida para o intervalo de ciclos considerado, pode ser expressa como:

$$
\Delta R=\frac{R i-R f}{R I} \cdot 100
$$

onde:

$\Delta \mathrm{R}=$ queda percentual da resistência mecânica inicial

$\mathrm{Ri}=$ Resistência mecânica injicial

$\mathrm{R} f=$ Resistência mecânica final para um determinado no de cicios.

A relação entre a queda percentual de resistência mecânica e a resistência mecânica inicial fornece um indice que exprime a suscetibilidade de uma determinada rocha em sotrer uma queda na sua resistência mecânica quando submetida a ciclos alternados de saturação em àgua e secagem em estufa. Este indice è designado coeficiente de alterabilidade especjufica $\mathrm{K}$, obtido pela fórmula:

$$
K=\frac{\Delta R}{R i}
$$

\section{6. - ANÁLISE QUALITATIVA}

A anälise qualitativa deverä constar de observações periödi cas sobre o aparecimento de fragmentos desagregados, trincados, fragmentados; modificações na cor dos fragmentos, - acompanhamen to fotográfico e exame petrogrä́fico antes do ensaio e após cada determinado no de ciclos, caso se mostrem afetados. Somente frag 
mentos maiores que $3 / 8 "(9,51 \mathrm{~mm})$, são adequados para esta anäli se:

\section{7. - RETATORIO}

o relatörio deve incluir os seguintes dados:

7.1 - Peso de cada fração de cada amostra antes do ensaio.

7.2 - Porcentagem de perda para cada penejraniento efetuado. A peneira usadia na determinação da perda deverá ser a prô pria peneira da granulação do ensaio de alteração.

7.3 - Resistência mecânica do naterial retido após cada de terminado no de ciclos.

7.4 - Resistência mecânica final após cada determinado no de ciclos.

7.5 - A queda percentual de resistência e o coeficiente de alterabilidade especifica.

7.6 - Fotografias de acompanhamento e analise petrogräica com fotomicrografias.

7.7 - Observações mäcroscöpicas sobre o estado de alteração apös ensaio.

7.8 - Se possivel, execução da difratometria de raios $x$ an tes do ensalo e após, no pó formado pela alteraçäo, para determinação da natureza do produto, e principalmente das proporções dos argilominerais presentes.

7.9 - Considerações a respeito da durabilidade da rocha.

\section{8. - OBSERVACÕES}

Utilizamse diferentes tipos de ensaios mecânicos neste mēto do, para verificar se:

A. Tanto a tenacidade como a resistência à abrasão, podem constjtuir-se em parâmetros mecânicos do estado de alteraçäo.

B. Como o cálculo dos valores nos ensaics mecânicos citados segue a mesma diretriz; os irdices de alterahilidade deverão ser 
aplicäveis para todos.

C. Conforme a quantidade de material djsponível, pode-se em pregar qualquer um dos parâmetros citados. 
ENSATO DE RESTSTENCIA Ä ALTERACÃO RM SOLUCÄO DE EITLENO GLICOL E MEDIDA DO COMPORTAMENIO MECANICO DA ROCHA

\section{1. - OBJETIVO}

Este método tem por finalidade determinar a resistência à altexação de rochas, submetidas a ciclos sucessivos de imersão em etileno ylicol, a secagem em estura a 1.00-110 $\mathrm{C}$. A solução de etileno gicol deverá pexnitir a identificação de rochas portado ras de argiloninerais expans vos, pois estas são particularmente suscetiveis à sua atuação. Este método permite tambëm una previs ̈̈o da queda cie resistência mecâni ca de agregados contendo pro porções variadas destes argillo minerais.

\section{2. - APARELHAGEM}

A aparelhagem necessäria constitui bàsicamente no seguinte: 2. - - Uma estufa ventilada capaz de manter uma temperatura de 105 a $110^{\circ} \mathrm{C}$ (ou $\left.60-70^{\circ} \mathrm{C}\right)$, com uma variação definia para um periodo de pelo menos 10 horas.

2.2 - Dara pesar o agregado miudo ou pequenas quantidades de agregado graudo, uma balança con capacidade de no minimo $500 \mathrm{~g}$ e sensibilíáade de 0,1 g, e paxa o glafido uma balança com capacidade de no minimo $5000 \mathrm{~g}$ e sensibilidade de $1 \mathrm{~g}$. 2.3 - Bandejas metälicas de folhas de dimensões adequadas, secagem dos materiais $n_{1}$ estufa.

2.4 - Solução de etilenoglicol incolor (1.jpida), que deverä ser sempre mantida coberta para evitar sua hidratação pe la umidade do ar.

2.5 - Recipientes fechados para imersão das amostras em lução de etulenoglicol. As amostras deverão estar complgamente submersas.

2.6 - Peneiras de majhas quadradas com caixilho metáli co de $203,2 \mathrm{~mm}$ de diametro,50 mm de altura, de acordo com a espe- 
cificą̧a AsTM: Eli-39, de abexturas nominais respectivamen te de $19,1 \mathrm{~mm} \mathrm{a} 15,9 \mathrm{~mm}$ e $1,68 \mathrm{~mm}$ para o ensaio de impacto Treton, ce $19,1 \mathrm{~mm}$ a $9,46 \mathrm{~mm}$ e $1,68 \mathrm{~mm}$ para o ensaio de abrasão los Angeles, de $38,1 \mathrm{~mm}$ a $25,4 \mathrm{~mm}$ para o ensaio de desgaste a umido.

2.7 - Apareiho Treton, do padrão DER: P81-52T.

2. $\delta$ - Mäquiria de abrasão Los Rngeles, conforme MB-170 do DER.

2.9 - Aparejho de desyaste a úmido, conforme descrito na pesquisa tec-7 e ilustrado no anexo I.

\section{3. - FREPERACAOO DAS AMOSTRAS}

Apös a britagem, peneirar o material a ser ensaiado em fraççes individuais conforme a sërie de peneiras mencionada.

roma"se iantas amostras de cada fração cyantos forem os en zaios mecánjcos intermediárius de controle a serem executarios, pa ra um determinado no de ciclos. Desta maneira, c peso de cada fração deve concordar com o indicado a seguir, para un ünico en saio mecânico a ser executado apös um determinado no de ciclos. Us pesos de cađa fração a ser ensaiada, deverão ser multiplica dos por $2,3, \ldots . ., n$, se o no de ensatos mecânicos intermedia rios de cortrole for respectivamente $1,2, \ldots, n-1$.

Granulação

(mrn)

19,1 a 25,4

19,1 a 15,9

19,1 a 12,7

12,7 a 9,5
Pesso da amostra para ensalo (kg)

1,2

1,5

5,0

5,0

Observa-se que as amostras obtidas devem ser bem lavadas e secas até um peso constante.

\section{4. - PROCEDIMENTO}

Apös lavagem e seciagem em estufa a $100-110^{\circ} \mathrm{C}$, até atingir - 
peso constante, separa-se a arlostra en difexentes frações confor me o item 2.6., por pereiramento. Pesam-se as quantidades nas di ferentes fraçôs que são colocadas separadanente em imersăo na solução de etilenoglicol. en recipientes fechaăos, por aproximadamente 6 horas.

Após o perî́odo de imersão, removem-se as amostras de agregä do e levam-se à estufa a $100-110^{\circ} \mathrm{C}$ atê que seja atingido um peso constante. Durante o periodo de secagem, retiram-se as amostras da estura, esfriam-se à temperatura ambiente e pesam-se a intervalos de 3 horas após pelo menos 8 horas na estufa. Após ter si do atingido o peso ccnstante, esfxianise as amostras (por aproxi. madamente 3 hoxas), à temperatura ambiente, quando estarão prepa radas para nova imersão em etilenogijcol.

Repete-se este processo de saturação e secagem alternada até que o no requerido de ciclos seja atingido.

\section{5. - ANALISE QUANTETATIVA}

A anälise quantitativa ê eferuada da seguinte forma:

Após cada 10 ciclos, retiranise amostras para a medida de sua resistência mecănica. para isto, ao ser atingido o ne de ci clos requerido e apös resfriamento, retiramse uma das amostras de cada traçäo. As demais amostras deverão continuar até o próxi mo ne de cj,clos reguerido. A amostra retirada deve ses lavada e seca a $100-110^{\circ} \mathrm{C}$ e peneirada durante 5 minutos com a mesma perei ra na qual tinham sido retidas antes do ensaio. A seguir, pesa se o material retido de cada fração com a precisão de $0,1 \mathrm{~g}$.

O material passante nas peneiras, constitui a perda em peso devido à ciclagem, correspondente à parte mais desagregável, de resistência mecânica nula. o material retido, pesado, das frações consideradas, é ensaiado da seguinte forma:

$\begin{array}{lll}\text { Granulação (nm) } & \text { Ensaio } & \text { Mëtodo } \\ 19,1 \text { a } 15,9 & \text { Impacto Treton } & \text { IPTM-52 } \\ 19,1 \text { a } 12,7 & \text { abrasão Ios Angeles } & \text { MB-170 } \\ 12,7 \text { a } 9,5 & \text {. desgaste a umido } & \begin{array}{l}\text { Descrito na pesqui } \\ \text { sa EPC-7 }\end{array}\end{array}$


o cälculo ã resistência mecänica final do matexial, para um determinado no de ciclos, $\vec{e}$ efetuado ponderando-se as resis tencias mecânicas dos materiais passante e retido após a cicla gem, através da förmula:

$$
R f=\frac{z \cdot R p+(100-\dot{X}) R r}{100}
$$

onde:

$X=\%$ de perda na ciclagem

$100-X=\%$ de material que resistiu ã ciclagem

$\mathrm{Rp}=$ Resistência mecânica do materiaj passante

$R r=$ Resistência mecânica do material retido

Rf = Resistência mecânica final para um determinado no de ciclos

Como $R p=0$, a förmula acina fica reduzida a:

$$
R f=\frac{(100-X) R r}{100}
$$

A queda percentual da resistência mecänica inicial, välica para o intervalo de ciclos considerado, pode ser expressa como:

$$
\Delta R=\frac{R i-R f}{R i} \cdot 100
$$

onde:

$$
\begin{aligned}
\Delta \mathrm{R}= & \text { queda percentual đa resistência mecânica injcial } \\
\mathrm{Ri}= & \text { Resistência mecânica inicial } \\
\mathrm{Rf}= & \text { Resistência mecânica final para un determinado no de } \\
& \text { ciclos }
\end{aligned}
$$

A relação entre a queda percentual de resistência mecânica e a resistência mecânica inicial fornece um indice que exprime a suscetibilidade de uma determinada rocha em sofrer uma queda na sua resistêncía mecânica quando submésida a ciclos alternados de saturaça em etilenoglicol e secagem em estufa. Este indice é designado coeficiente de alterabilidade especifica $K$, obtido pe la formula: 


$$
K=\frac{\Delta R}{R i}
$$

\section{6 . - ANÄISSE QUALITATIUA}

A anālise qualitativa deverá constar de observações periódi cas sobre o aparecinento de fragmentos desagregados, trincados, fragmentados; modificações na cor dos fragmentos; acompanhamento fotogräfico e exame petrogräfico antes do ensalo e após cada cie terminado no de ciclos, caso se mostrem afetados. Somente fraq mertos maiores que $3 / 3^{\prime \prime}(9,51 \mathrm{~mm})$, são adequados para esta anäl se.

\section{7. - REIATORIO}

O relatôrio deve incluir os seguintes dados:

7.1.- Peso de cada fração de cada amostra antes do ensaio. 7.2 - Porcentagem de perda para cada peneiramento efetuado. A peneira us dáa na determinação da perda deverá ser a pró pria penełra da granulação do ensało de alteração.

\%.3 - Resistância mecânica do material retido apôs cada determinado no de ciclos.

7.4 - Resistência mecânica final após cada determinado n웅 de ciclos.

7.5 - A queda percentual de resiscência mecânica e o coeficience de alter ubilidade especifica.

7.6 - Fotografias de acompanhamento e anälise petrográfica com fotomicrogratias.

7.7 - Observações macroscópicas sobre o estado de alteração apōs ensaio.

7.8 - Se possível, execução da difratometria de raios-x an tes do ensaio $e$ apös, no pó formado pela alteração, para de terminação da natureza do produto e, principalmante das pro porções dos argilominerais presentes.

7.9 - Considerações a respeito da durabilidade da rocha. 


\section{8. - OBSERVACÕES}

Utiliza-se diferentes tipos de ensaios mecanicos neste mêto do, para verificar se:

A. Tanto a tenacidade como a resistência ả abrasão, podem constituir-se em parâmetros mecânjcos do estado de alteração.

B. Como o câlculo dos valores nos ensaios mecânicos citados segue a mesma dixetriz, os indices de alterabilidade deverão ser ap li căveis para toros.

c. Conforme a quantidade de material disponfvel, pode-se em pregar qualquer un dos parâmetros citados. 
ENSAIO DE RESTSTENCIA A AITERACÃO EM SOLUCTO SATURADA DE SULFATO DE SODIO E MEDIDA DO COMPORMAMENTO MECÂNICO DA ROCHA

\section{1. - OBJETTVO}

Este método tem por finalidade deteminar a resistência à alteração de rochas, submetidas a cicios sucessivos de satuxação em solução saturada de sulfato de södio e secagem em estufa a $100-110^{\circ} \mathrm{C}$. Este mëtodo permite tamberm una previsäo da queda de resistência mecânica principalmente de agregados microfraturados, quando submetidos a mudanças de condições físicas: durante empre go.

\section{2. - APARE LEHAGEM}

A aparelhagem necessāria constitui basicamente no seguirte: 2.1. - Uma estufa ventilada capaz de manter uma temperatura de 105 a $110^{\circ} \mathrm{C}$ (ou $60-70^{\circ} \mathrm{C}$ ), com uma variação definia para um período de pelo menos 10 horas.

2.2 - Para pesax o agregado mi údo ou pequenas quantidades de agregado graúdo, uma balança com capacidade de no mínimo 500.9 e sensibilidade de $0,1.9$, e paxa o graúco uma balança com capacidade de no mínimo $5000 \mathrm{~g}$ e serusibilidade de $1 \mathrm{~g}$.

2.3 - Bandejas metálicas de folras de dinensōes aciequadas,para secagem dos materiais na estufa*

2.4 - Prepara-se uma solução saturada de $\mathrm{Na}_{2} \mathrm{SO}_{4}$ dissolven do-se este sal em ägua à temperatura de $20-30^{\circ} \mathrm{C}$. Adiciona se sal suficiente, seja anidro ou ridratado, para assegurar não somente saturação mas também a presença de cristais em excesşn, quando a solução estiver pronta para uso nos en saios $(350 \mathrm{~g}$ de sal anidro ou $750 \mathrm{~g}$ de sal decahidratado por litro de àgua). Agita-se cuidadosamente a mistura duran te a adição de sal e também a solução (prontai em interva los frequentes, até ser usada. Para reduzir a evaporação e preventir contaminação, a solução deve ser mantida sempe 
coberta, mantendo-a pelo menos durante 48 horas, antes do uso, deve-se dispersar o sal no recipiente, agitando-se cui dadosamente a solução e determinamse a sua densidade. A solução ao ser usada deverá ter uma densidade le 1.151 1.174 .

2.5 - Envölucros para imersão das amostras de agregados na solugão, de acordo com o procedimento deste ensaio, que de vem ser perfurados para permitir livre acesso da soluçăo à amostra e arenagem da solução sem perda de agregado.

2.6 - Estes ervolucros mais amostxas e a sclução, devein ser colocados en recipientes fechados. O volume da solução deve ser no mínimo 5 vezes maior que o volume da amostra a ser imergida.

2.7 - Peneiras de malhas quadradas com caixilho metálico de 203,2 mm de diâmetro, $50 \mathrm{~mm}$ de altura, de acordo com a espe cificação AsTM: Ell--39, de aberturas nominais respectivanen te de $19,1 \mathrm{~mm}$ a $15,9 \mathrm{rm}$ e $1,68 \mathrm{~mm}$ para o ensaio de impacto Treton, de $19,1 \mathrm{~mm}$ a $9,46 \mathrm{~mm}$ e $1,68 \mathrm{rm}$ para o ensaio de abrasão los Angeles, de 38, 1 mm a 25,4 mm para o ensaio de desgaste a ümido.

2.8 - Aparelho Treton, do paçrão DER: P8I-52T

2.9 - Mäquina de abrasão Los Angeles, conforme MB-I70 do DER.

2.10 - Aparelho de desgaste a imido, conforme descrito na pesquisa ERC-7 e ilustrado no anexo $I$.

\section{3. - PREPARAÇ̃O DAS AMOSTRAS}

Apōs a britagem, peneirar o material a ser ensaiado em frações individuais conforme a série de peneiras mencionada.

Toma-se tantas amostras de cada fração quantos forem os en saios mecânicos intermediärios de controle a serein executados, pa ra um determinado no de ciclos. Desta maneira, o peso de cada fração deve concordar com o inaicado a seguir, para um ünico en saio mecâníco a ser executado apōs um determinado no de cj clos. 
Os pesos de cada fração a ser ensaiada, deverão ser multiplica das por $2,3, \ldots . ., n$, se o no de ensaios mecânicos internedia..rios de controle fôr respectivamente $1,2, \ldots \ldots, r-1$.

Granulação

(min)

$$
\begin{aligned}
& 38,1 \text { a } 25,4 \\
& 19,1 \text { a } 15,9 \\
& 19,1 \text { a } 12,7 \\
& 12,7 \text { a } 9,5
\end{aligned}
$$

Peso da amostra para ensaio

$(\mathrm{kg})^{\circ}$

1,2

7,5

5,0

5,0

Observa-se que as amostras obtidas devem ser bem lavadas e secas ate un peso constante.

\section{4. - PROCEDTMENTO}

Apös lavagem e secagem em estufa a 100-110 ${ }^{\circ} \mathrm{C}$, até atingir. peso conitante, separa-se a amostra em diferentes fxações confor me 0 item 2.7., por peneixamento. Pesam-sc as quantidades nas ai ferentes frações, gue são colocadas separadamente em envölucros perfurkios. Em seguida, são colocados em imersão na solução pre parada de $\mathrm{Na}_{2} \mathrm{SO}_{4}$, dentro de um recipiente fechado, por não menos do que 16 horas e nem mais do que 18 horas, de tal forma que a solução cubra totalmente as amostras.

Após o periodo de imexsão, removem-se as amostras de agrega do da solução, permitindo sua drenagem por aproximadamente $15 \mathrm{mi}$ nutos e colocam-se na estufa a $100-110^{\circ} \mathrm{C}$ até que seja acingido um peso constante. Durante o perioajo de isecagem, retiram-se as amostras da estufa, esfriam-se à temperatura ambiente e pesam-se a intervalos de 3 horas apös pelo menos 8 hcras na estufa. Apös tex sido atingido o peso constante, esfriam-se as amostras (por aproximac̈amente 3 horas), 3 temperatura ambiente, quando estarão preparadas para nova imersão na solução.

Repete-se o processo de imersão e secagem alternada até que - ne requerido de diclos seja atingido. 


\section{5. - ANAALISE QUANTITATIVA}

A anälise quantitativa ë efetuada da seguinte forma:

Após cada 5 ou 10 cijclos, retiramme amostras para a medida de sua resistencia mecânica. Para isto, após atingido o no de ci clos requerido e após resfriamento, retira-se uma das amostras de cada fração que é lavada, extraindo-se o residuo de $\mathrm{Na}_{2} \mathrm{SO}_{4}$ cori uma solução $5 \%$ de $\mathrm{BaCl}_{2}$. As demais amostras deverão continuar. atë o pröximo no de ciclos requerido. Na anostra retirada, apǰs a remoçäo de $\mathrm{Na}_{2} \mathrm{SO}_{4}$, cada fraçäo deve ser secada a 100-1I0 $\mathrm{C}$ ate peso constante e peneirada durante 5 minutos com a mesma peneira na qual as amostras tinham sido retidas antes co ensaio. A se guix, pesa-se o material retido de cada fração com a precisão de 0,19

O material passante nas peneiras, conetitui a pera eni peso devido à ciclagem, correspondente à parte rnais desagregävel, de resistência mecânica nula. o material retido, pesado, das frá çôes consideradas, è ensaiado da seguinte forma:

\begin{tabular}{|c|c|c|}
\hline Granulação (mm) & Ensaio & Mëtodo \\
\hline 19,1 a 15,9 & impacto Treton & IPT $M-52$ \\
\hline $\begin{array}{r}19,1 \text { a } 12,7 \\
12,7 \text { a } 9,5\end{array}$ & abras z̃o Los Angejes & $\mathrm{MB}-170$ \\
\hline 38,1 a 25,4 & desgaste a ümido & $\begin{array}{l}\text { Descrito na pes- } \\
\text { quisa FPC-7 }\end{array}$ \\
\hline
\end{tabular}

o cälculo da resistência mecânica final cio material, para um determinado no de ciclos, é efetuado ponderando-se as resis tências mecânicas dos materiais passante e retido apös a cicla gem, atravës da fórmula:

$$
R f=\frac{X \cdot R p+(100-X) R r}{100}
$$

onde: $X=8$ de perda na ciclagem

$100-\mathrm{x}=\%$ de material que resistiu à ciclagem

$\mathrm{Rp}=$ Resistência mecânica do material passante

$\mathrm{Rr}=$ Resistência mecânica do material retido

$\mathrm{RE}=$ Resistência mecânica final para um determinado no de ciclos. 
Como'Rp = 0, a fórmula acima fica reduzida a:

$$
R f=\frac{(100-x) R r}{100}
$$

A queda percentual da resistência mecânica inicial, vālida para o intervalo de clalos considerado, pode ser expressa como:

$$
\Delta R=\frac{R i-R F}{R E} \quad 100
$$

onde:

$$
\begin{aligned}
\Delta \mathrm{R}= & \text { queda percentual da resistência mecânica inicial } \\
\mathrm{Ri}= & \text { Resistência mecânica inicial } \\
\mathrm{Rf}= & \text { Resistềncia mecânica final para um determinado n? } \\
& \text { de ciclos. }
\end{aligned}
$$

A relaçäo entre a queda percentual de resistência mecânica e a resistência mecânica inicial fornece um indice que exprime a suscetibilidade de uma determinada rocha em sofrer uma queda na sua resistência mecânica quando submetida a ciclos de saturação em solução de sulfato de sódio e secagem em estutia. Este indice é designado coeficiente de alterabilidede especifica $K$, outido pela formula:

$$
\mathrm{K}=\frac{\Delta R}{\mathrm{Ri}}
$$

\section{6. - ANALISE QUALITATIVA}

A anälise qualitativa deverá constar de observaçũes periódi cas sobre o aparecimento de fragmentos desagregados; trincados, fragmentados; modificações na cor dos fragmentos; acompanhamento fotogrä́fico e exame petrográfico antes do ensaio e após cada determinado no de ciclos, caso se mostrem afetados. Somente frag mentos maiores que $3 / 8 "(9,51 \mathrm{~mm})$, são adequados para esta anäli se.

\section{7. - REIETSRIO}

O relatörio deve incluir os seguintes dados:

7.1 - Peso de cada fração de cada amostra antes do ensaio. 
7.2 - Porcentagem de perda para cada pieneixamento efetuado. A peneira us ada na determinação da perda deverä sex a pró pria penejra da granulação do ensaio de alteração.

7.3 - Resistência mecânica do material retido após cada de terminado no de ciclos.

7.4 - Resistência mecónica final após cada determinado no de ciclos.

7.5 - A queda percentual de resistência mecânjca e o coeficiente de alterabiljade especifica.

7.6 - Eotografias de acomoanhamento e análise petrogräfica com fotomicrografias.

7.7 - Observações macroscópicas sobre o estado de alteração apös ensaio.

7.8 - Se possivel, execução da difratometxia de iatus $x$ an tes do ensato e apös, no pó formado pela alteraçăo, para de terminação da natureza do produto e, principalmente das pro porções dos argilominerais presentes.

7.9 - Considerações a respejto da durabijidade ha rólıa.

\section{8. - OBSERVACOESS}

Utiliza-se diferentes tipos de ensaios mecânicos neste mëto do, para verificar se:

A. Tanto a tenacidade como a resistência a abrasão, poder. constituir-se em parâmetros mecânicos do estado de aiteração.

B. Como o cálculo dos valores nos ensaios mecânicos citados segue a mesma diretriz, os indices ae alterabizidade deverão ser aplicáveis para todos.

C. Conforme a quantidade de material disponivel, pode-se em pregar qualquer um dos parânetros citados.

D. A alteração com solução de sulfato de sódio segue aproxi madamente o método ASTM-C 88:69, modificado. 
ENSAIO DE RESISTENCIA A ALTERACÃO EM EXPOSICĂO NATIURAI E MEDIDÁ DO COMPORTAMENTO MECÄIICO DA ROCHA

\section{1. - OBJETIVO}

Este método tem por finalidade verificar a resistencia a al teração de rochas, submetidas às condições intempéricas, visando - possivel aproveitamento das mesmas como material de construção. A anälise quantitativa do método, permite avaliax a influência das condiçôes climăticas sobre as caracteristiaas mecânicas da rocha.

\section{2. - APARELHAGEM}

A aparelhagem necessäria constitui basicamente no seguinte:

2.1 - Uma estufa ventilada capaz de manter una temperatura de 105 a $110^{\circ} \mathrm{C}$ (ou $60-70^{\circ} \mathrm{C}$ ), com una variação definida para um periodo de pelo menos 10 horas.

2.2 - Para pesar o agregado mijuo ou pequenas quantidades de agregado graúdo, uma balança com capacidade de nc mrıimo 500 g e sensibilidade de 0,1 g, e para o graudo uma balança com capacidade de no mínimo $5000 \mathrm{~g}$ e sersibilidade de $1 \mathrm{~g}$.

2.3 - As amostras poderão ser colocadas dentro de caixas de madeira providas de tela, devidamente numeradas, e levadasà exposição natural.

2.4 - Bandejas metálicas de folhas de aimensões adequadas para secagem dos materiais na escufa.

2.5 - Pereiras de malhas quadradas corn caixilfo netálico de 203,2 mm de diâmetro, $50 \mathrm{~mm}$ de altura, de acordo com a espe cificação ASTM: E11-39, de aberturas nominais respectivamen te de $19,1 \mathrm{~mm}$ a $15,9 \mathrm{~mm}$ e $1,68 \mathrm{~mm}$ para o ensaio de impacto Tretcn, de $19,1 \mathrm{~mm}$ a $9,46 \mathrm{~mm}$ e $1,68 \mathrm{~mm}$ para o ensaio de abrasão Los Angeles, de $38,1 \mathrm{~mm}$ a $25,4 \mathrm{~mm}$ para o ensaio de desgaste a umido. 
2.5 - Aparelho greton, do padrão DER: P81 $52 \mathrm{~T}$.

2.7 - Mäquina de abrasão Los Angeles; conforme MBm 170 ABNT.

2.8 - Aparelho de desgaste a umido, conforme descrito pesquisa $\mathrm{EPC}-7$ e ilustrado no anexo $\mathrm{I}$.

\section{3. - PREPARACÄO DAS AMOSTRAS}

Apös a britagem, peneirar o material a ser ensaiado em fra ções individuais conforme a sërie de peneiras mencionada.

Tomamse tartas anostras de cada fração quantos forem os en saios necânicos intermediärios de controle a sexem executados, pa ra um determinado tempo de exposjção. Desta maneira, o peso de cada fração deve concorảax com o indicado a seguix, para um unico ensajo mecânico a ser executado após um determinado tempo.

os pesos de cada Exação a ser ensaiada, deverão ser multipì cacios por 2, 3,...n, se o no de ensaios mecanicos intermeriz . rios de controle for respectivamente $1,2, \ldots, r_{1}-1$.

$\begin{array}{cc}\begin{array}{c}\text { Granulaçäo } \\ (\mathrm{mm})\end{array} & \text { Peso da amostra para ensaio } \\ (\mathrm{kg}) & 1,2 \\ 38,1 \text { a } 25,4 & 1,5 \\ 19,1 \text { a } 15,9 & 5,0 \\ 19,1 \text { a } 12,7 & 5,0 \\ 12,7 \text { a } 9,5 & \end{array}$

Observame que as amostras obtidas devem ser bem lavadas e secas atè um peso constante.

\section{4. - PROCEDIMENTO}

Apōs lavagem e secagem em estufà à $100-110^{\circ} \mathrm{C}$, até atingir peso constante, separa-se a amostra em diferentes frações confor me o i.tem 2.5., por pereiramento. Pesam-se as quantidades nas diferentes frações, que são colocadas separadanente em caixas de madeira providas de tela, devidamente identificadas, e levadas à exposição natural. 
Após 1 més de exposição, retira-se uma das amostras de cada fração para medida de sua resistência mecânica. As demais ámos tras deverão continuar atë os proximos meses requexidos:

\section{5. - ANAIISE QUANTITATIVA}

A anālise quantitativa é efetuada da seguinte forma:

A amostra retiracia deve ser lavada e seca na estufa a 100$110^{\circ} \mathrm{C}$. Durante o periodo de secagem, retiram-se as amostras da estufa, esfriam-se à temperatura ambiente e pesam-se a interraios de 3 horas após pelo menos 3 horas na estufa. Apös tex sido atin gido o peso constante, esfrian-se as amostras (por aproximacianen te 3 horas), que são peneiradas durante 5 minutos com a mesma pe neira na qual. tinham sido retidas antes do ensaio. A seguir, pesa-se o material retido de cada fração com a precisão de $0,1 \mathrm{~g}$."

o material passante nas peneiras, constitui a perda em peso devido à alteração, correspondente à parte mais desagreyāvel, de resistência mecânica nula. O material retido, pesado, das fra cốs consideradas, é ensalado da seguinte forma:

$\begin{array}{ccc}\text { Granulação (m) } & \text { Ensalo } & \text { Mëtodo } \\ 19,1 \text { a } 15,9 & \text { impacto Treton } & \text { IPT M-52 } \\ 19,1 \text { a } 12,7 & \text { abrasão Los Angeles } & \text { MB-170 } \\ 12,7 \text { a } 9,5 & \text { desgaste a Lmido } & \text { Descrito na pesquisa } \\ 38,1 \text { a } 25,4 & \text { EPC-7 }\end{array}$

- cálculo da resistência mecânica final do material, para um determinado tempo de exposiçäo è efetuado ponderando-se as re sistências mecânicás dos materiais passante e retido após a expo sição, atravēs da formula:

$$
R f=\frac{X R P+(100-X) R E}{100}
$$

onde:

$x=\frac{\circ}{\partial}$ de perda na exposição

$100-x=8$ de material que resistiu à exposição 
$R p=$ Resistência mecânica do material passante

$R x=$ Resistência mecânica do material retido

Rf = Resistërcia mecânica finaJ para um tempo determinado de exposição

Como $\mathrm{Rp}=0$, a fómula acima fica reduzida a:

$$
R E=\frac{(100-X) R}{100}
$$

A queda pexcentual da resistência mecänica inicial, välida paxa o intervalo de tempo de exposicão consiclerado, pode ser ex pressa como:

$$
\Delta R=\frac{R i-R F}{R i} \cdot 100
$$

onde:

$\Delta \mathrm{R}=$ queda percentual da resistência mecänica iniciai

Ri = Resistência mecânica inicial

Rf = Resistência mecânica final para um determinado tempo de exposiçào.

A relação entre a queda percentual de resistênci mecânica - a resistência mecânica inicial fornece lim indice que exprime a suscetibilidade de uma determinada rocha em sofrer uma queda na sua resistêricia mecanica quando submetida às condiçoes naturais. Este indice é designado coeficlente de alterabilidade especifica K, obtido pela fórmula:

$$
K=\frac{\Delta R}{R \dot{I}}
$$

\section{6. - ANAIISE QUAIITAIIVA}

A anälise qualitativa deverä constar de observaçẽes nensais sobre o aparecimento de tragmentos desagregados, trincados, irag mentados; modificações na cor dos fragmentos; acompanhamento fotogräfico e exame petrogräfico antes do ensaio e após caća tempo de exposição, caso se mostrem afetados. Somente fragmentos maiores que $3 / 8^{\prime \prime}(9,51 \mathrm{~mm})$ são adequados para esta anälise. 
7. - REIATORIO

o relatório deve incluir os seguintes dados:

7.1 - Peso de cada fraçáo de cada amostra antes do ensaio.

7.2 - Porcentagem de perda para cada perieiramento efetuado. A peneira usada na determinação da perda deverá ser a pró pria peneira da granulação do ensaio de alteração.

7.3 - Resjsçência mecănica do material retido apös cada de terminado tempo de exposição.

7.4 - Resistência mecânica Einat apös cade determinado tempo de exposição.

17.5 - A queáa percentuai de resistência mecânica e o coeficierte de aiterabiliaade especifica.

7.6 - Fotografias de acompanhamento e anälise petrográfica com fotomi crografias.

7.7 - Observações macruscópicas sobre o estado de alteração após ensaios.

7.8 - Resumo das condiçöes climäticas durante o mes, inciluin do precipjtação, variações termometricas, dias de sol, geacas, umidade relativa do ar, etc.

7.9 - Se possível, execução da difrztometria de raios $x$ antes do ensaio e ápós, no pö formado pela alteração, para de terminayão da natureza do pioduto e, principalmente das pro porções dos argilonituerais presentes.

7.10 - Considerações a respeito da durabilidade da rocha.

\section{8. - OBSERVAÇÕES}

Vtiliza-se diferentes tipos de ensaios mecânicos neste méto do, para verificar se:

A. Tanto a tenacidade como a resiscência à abràsão, podem constituix-se em parâmetros mecânicos do estado de alteração.

B. Como o câlculo dos valores nos ensaios mecânicos citados segue a mesma diretriz, os indices de alterabilidade deverão ser 
aplicäveis para todos.

c. Conforme a quantidade de material disponivel, pode-se em pregar qualquer um dos parâmetros citados. 


\section{ESQUEMA DO APARELHO DE DESGASTE A UMIDO}

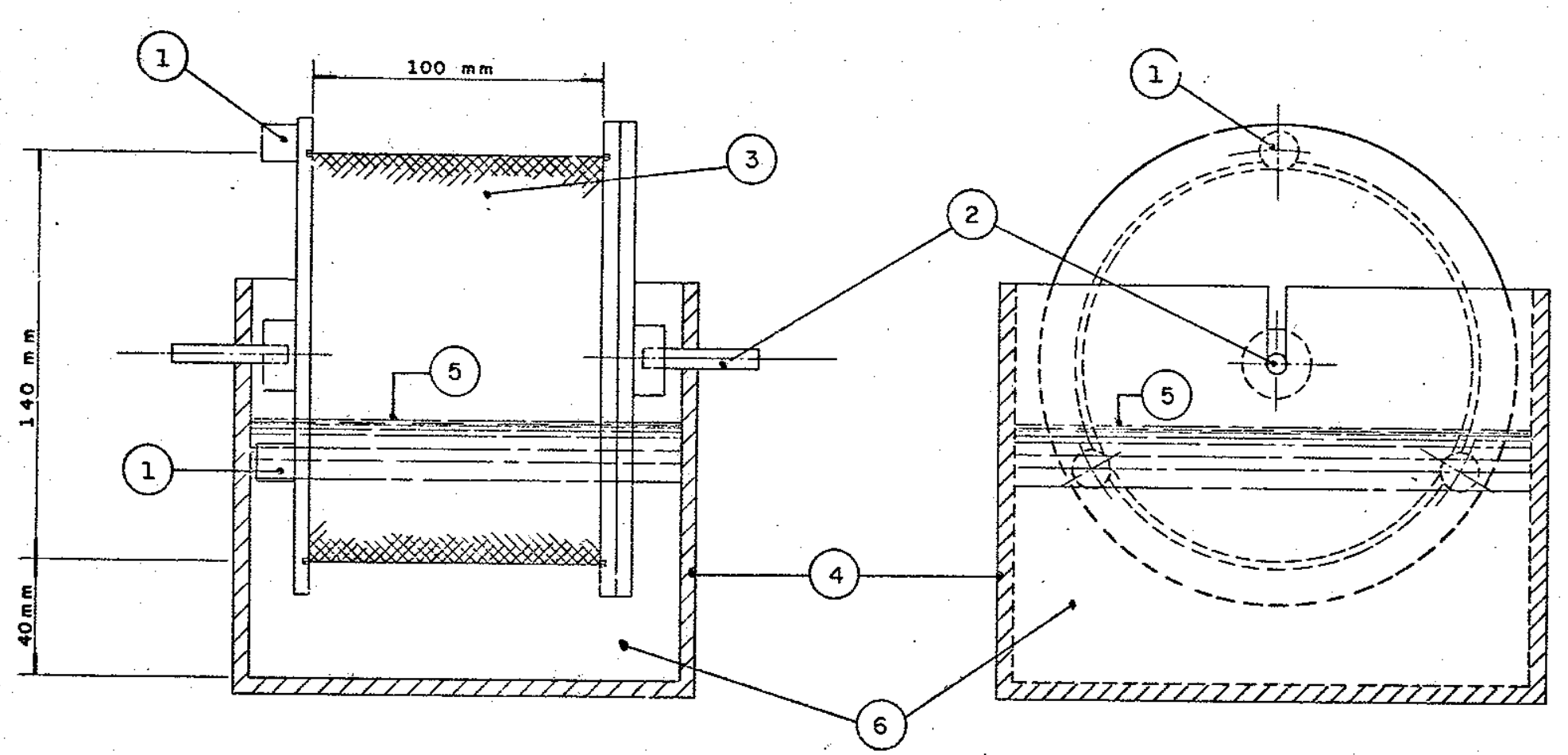

CORTE LONGITUDINAL

CORTE TRANSVERSAL
1. Parafuso de fixação da tampa

2. Eixo do tambor

3. Tumbox crivado

4. Recipiente de acrili co

5. Nível do Iiquido

6. Líquido de imersão 
1

1

APENDTCE:

PROCERMMEN'LO ESTATISTICO ADOTADO PARA ALÄIISE DE RESULCADOS 


\section{PROCEDIMENTO ESTATISTICO PARA DIMENSIOUAMENTO DE AMOSTRAS,"APLI--}

\section{CABIIIDADE DO METODO DE ENSAIO E CORRELACÕES}

\section{GENERAIIDADES}

Fim ensaios físicos score rochas, a média de uma conjunto de leituras é considerado como sendo representativa do todo. As di ferenças de resultados que se obtem ao efetuarnos tais ensaios, são devidas a diversos fatores:

1. Heterogeneidade dos materiais rochosos, ocasionando vä riações nas amostras ensaiadas e variações entre uma amostra e as demais, procedentes de uma mesma jazida.

2. Falta de uniformidade na preparação dos corpos de prova.

3. Erros instrumentais com o emprego de aparelhos nâo afexi dos periodicamente.

4. Arros do operador nos ensaios e nas leituras.

Ao considerarmos e avaliarmos erros de medida, é de grandevalia ter em mente o esquema de medida emoregado. A determinação de indices físicos mezânicos em rochas, constitui um caso de atua ção direte de um sistema físico. Entretanto, qualquer que seja - esquema de meaida empregado, o valor 20 nümero atribuido como resultado das medidas para descrever a magnjtude da propriedads medida, deveră ter um maior ou menox erro, 1.ê., deverá afastar.se um certo tanto do valor real da quantidade. Nenhuna medida seja elaborada ou precisa ou repetida muitas vezes, poderá ja mais eliminar completamente esta incerteza ( 10 ). Então, o va Ior real de uma quantidade física medida nunca poderá ser obicia com exatidão absoluta. Uma das fases mais importantes na arte de medida, consiste na padronização de procedimenios, de maneira a reduzir os erros de medida a limites toleräveis para os objeti vos em vista.

Așsim, se uma amostra é representativa de uma populaçăo, con clusões importantes podem frequentemente serem inferidas a par tir da anälise da amostra. A parte da estatistica tratando com 
condiçöes sob os quais tal inferência é väliạa è chamada inferên cia estatística. Como esta infexêricia não pode ser absolutamente certa, aplica-se o teoria das probabilidades ao extrairmos as condições. O emprego de mëtodos estatísticos na anälise dos re sultados obtidos proporciona então o conhecimento do padrão ca racterístico de vaijag̃ão para cada rocha e equipamento de ensaio.

De acordo com considine e Ross ( 10 ), ao estimar a magnitude da incerteza ou exro no valor atribuido a una quantidade me dida, devemos fazer uma distinção entre 2 classes gerais de ex ros: erros sistemáticos e erros ranan̂micos. Erros sistemáticos são aqueles que são consistentemente repetidos com a repetição -do ensajo e, exros rardömicos são acidentais, cuja magnitude e sinal, flutuam de forma que não pode ser prevista a partir do contrecumento do sistema de medida e das condiçốes de medida.

Deste modo, ao efetuarmos medidas de propriedades físicas de rochas através de ensaios temolögj.cos, os resultados obtidos podem estar afetados por estas classes de erros. Neste caso, a dispersão nos resultados é devida a todos os fatores atuantes, mencionados anteriormente. A esta dispersão,podemos chanar de dispersão total. Conforme Hinsworth (in 19), a dispersão total. é a soma das dispersões causadas por fontes de variação atuando in dependertemente. Se as medidas forem executadas sob as nesmas condiçöes, em corpos de prova teoricamence isotröpicos, a disper são obtida deverä corresponder à dispersão devida unicamente ao instrumenio. Este fato serä de grande valia no dimensionamento da amostra, como se verä a seguir.

\section{INFERENCIA ESTAIISTICA}

Muita confusão tem surgido na aplicação de mêtodos estatísticos por parte dos pesquisadores devido aos numerozos mëtodos para registrar dados e estabelecer a confiabilidade de suas ana Iises. A inferência estatística pode ccnstituir-se em valioso instrumento na interpretação de resultados de ensaios, mas deve mos ter em mente que suas teorias constituem verdades matemäti cas nem sempre aplicáveis aos conceitos geológicos.

Não constitui objetivo deste apênaice, nem certamente nossa 
intenção, introduzir una massa de dados estatísticos e teorias estatisticas complexas relativas à determinação da precisão e confiabilidade de medidas envolvendo flutuações randômicas. o nosso objetivo ê apresentar apenas um esguema de procedimento es tatístico, que permita visualizac a sequência àe operações estatisticas a ser efetuada, ao se testar a aplicabilidade de um de terminado ensaio tecnológico.

Para fins präticos de aplicação da anälise estatistica a agregados rochosos: amite-se que seja do tipo normal (Gauss Laplace), a curva de distribujção de fueguencias das caracteristicas fisicas $(12-30)$, constituindo un dos exemplos mais impor tantes de una distribuição probabiljstica continua.

o cortrole de qualjade dos resultados pode, pois, ser assocjado à curva normal. representativa de caöa caso, caracteri.. zada pelos seguintes parâmetros:

1. Média (Média arjtmëtica, $\bar{x}$ )

E o valor tipico ou representativo de um conjunto de resultados. Una das médias majs comuns ë a mëdia aritmëtica $\bar{x}$, que constitui a soma de todas as observaçôes em uma amostra divi dìca pelo no de observações.

$$
\bar{x}=\frac{x_{3}+x_{2}+\ldots+x_{n}}{n}=-\frac{I}{n} \sum_{i=1}^{n} x_{i}
$$

\section{Medidas de dispersão}

- grau na qual os valores numëricos tendem a se afastar de um valor médio é chamado variação ou dispersão dos resultados. Uma medida oomum da dispersão ê a variância.

\section{1 - Variância}

A variancia è a soma dos quadrados dos desvios de observações individuais da média, dividido pelo nc total de observações. A variância da amostra $\underline{S^{2}}$ é calculada pela förmula:

$$
s^{2}=\frac{\sum_{i=1}^{n}(x i-\bar{x})^{2}}{n}
$$


A relaçäo é dividida pox $\underline{n}$ quando $n>30$ e por $n-1$, quian do $n \leq 30$. para valores gravies de $n$, não hâ praticamente diferença entre os valores de $s^{2}$ determinados, usando-se ( $n$ ) ou $(n-1)$. O resultado obtido pelo uso de $(n-1)$ no denominador em lugar de $(n)$, e considerado como representando uma estimativa melhor e menos afastada da variância da popula .ção, da qual a amostra foi extraía.

2.2 - Desvio padrão

A dispersão das observaçós sobre a mëdia ë usualmente medida pelo desvio padrão, que é definido como a raiz quadxada positiva da vaxiancia $\mathrm{s}^{2}$. E obtida pela equação:

$$
s=\sqrt{\frac{\sum_{i=j}^{n}(x i-\bar{x})^{2}}{n}}
$$

O desvio padrão pode tambern ser obtido, sem se anjouIar inicialmente a média da amostra, usando-se a equaģão equivalente simplificada da forma:

$$
s=\sqrt{\frac{\sum_{i=1}^{n} x_{i}^{2}-\frac{\left(\sum_{i=1}^{n} x_{i}\right)^{2}}{n}}{n}}
$$

\section{3 - Coeficiente de variação}

A variação real como è determilada a partir do desvio padrão ou outra medida de dispexsão é chamada de dispersão absoluta. Entretanto, para se comparar o grau de variação dentro da amostra ou entre amostras em relação a diferentes propriedades, 'é mais conveniente expressar o desvio paarão $S$, como uma porcencragem da nièdia $\bar{x}$. Este valor fornece uma medida da dispersão relativa, chamada coeficiente de variação $\mathrm{C}_{\mathrm{V}}$. Este coeficiente é usualmente expresso como uma por centagem, e $\vec{e}$ dado pela fórmula:

$$
C_{V}=\frac{S}{\bar{x}} 100
$$


Como êma relação de 2 quantidades com a mesma unida de de medida, o coeficiente de variaçäo é independente da unidade empregada.

\section{INTERVALO DE CONFIANCA}

Numa distribuiçăo gaussiana, as obsexvaçöes que diferem pou co de mëdia, ocorrem mais frequentemente do que observações que diferem considexa relmente da mëía. Relacionando-se a frequência de ocorcênci a de uma observaçăo com o quanto ela difere da méäa da populaz̧ão, a curva representativa desta aistribuição tem a aparencia fusica de um sino simetrico, extendendo"se infinitamen te para anibos as extremidades:

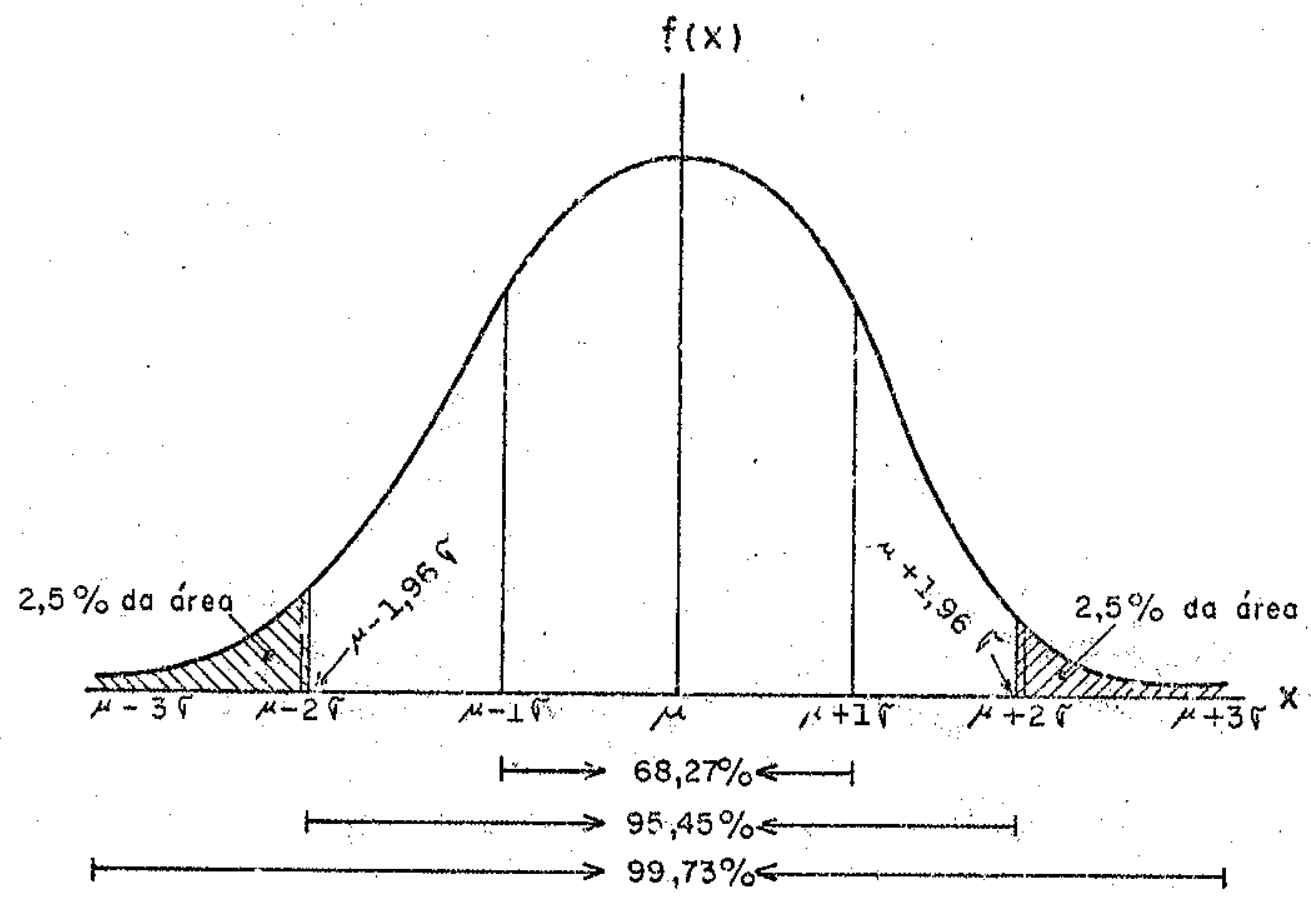

Se a área total entre a curva e o eixo x ê de 100\%, então, a porção da ärea sob a curva entre 2 valores quaisquer de $x$ è completamenta determinada por $\mu$ e $\sigma$. For integração, encontra-se que $68,27 \%$ da ärea total fica no intervalo $\mu \pm 1 \sigma$, enquanto que $95,45 \%$ das observações estáo no intervalo $\mu \pm 2 \sigma$. Somente $0,27 \%$ dà frequência total fica alēm de $\mu \pm 3 \sigma$. o gráfico indica tambëm que $5 \%$ da àrea total fica além de $\mu \pm 1,960$. 
E possivel então, pela anälise estatistica de dados determj nar uma flutuaça da dispersão do vajor mëilo dentro do qual pode ser esperado que esteja uma certa fiação de todos os valores. Esta flutuação é chamada de jntervalo de confiança, e a probahiIidade que o valor de uma observação escolhida ao acaso esteje dentro deste intervalo ë chamada nível de confiança.

Se o no de observações ë grande e suas dispersões são randô micas, diversos intervalos de confiança em volta do valor médio $\mu$ podem ser determinados através da expessão gexal: $\bar{x} \pm \xi \sigma$ ( $\xi$ tabelado e definido para um detecminado nivel de confiança e no de observações, na tabela de äreas sob a curva normal).

se o no de observaçöes ë pequeno e o desvio padrão o não é conhecido com exatidão, estes intervalos devern ser ampliados. Nes. te caso, devemos calcular o desvio padrão da amostra $s$, e multiplicar este valor por um fator aropriado, o coeficiente $t$ de Student, para estabelecer o intervalo de confiança, isto $\breve{e}$ o in tervalo dentro do qual espera-se encontrar uma observação sele. cionada ao acaso, com um determinado nivel de confiança. Do mesm mo modo, podenos achar diversos intervalos de confiança em volta do valor médio $\mu$, que podem ser determinados atraves da expressa geral $\bar{x} \pm$ to (t tabelado e definido para um determinado nível de confiança $e$ no de observações, na tabela de distribuição t ae Student).

Para se obter os intervalos de confiança para a média de um grupo de observações, considerame o desvio padrão das médias.,

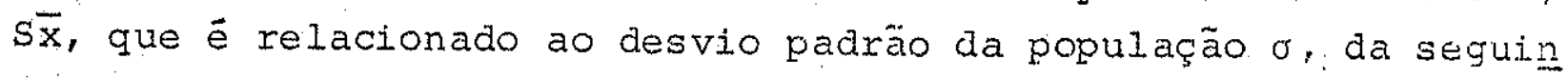
te maneira:

$$
s \bar{x} \frac{\sigma}{\sqrt{N}}
$$

Estatisticamente considera-se esta grandeza como erro padrã.

como a distribuição anostral das mëdias tem uma mëdia e um desvio padrão $s \bar{x}$ e è normal na forma ( 29 ), ë possível determinar a probabilidade que a mëdia da arnostra $\bar{x}$, possa ser encontra da dentro de uma distância específica da mëdia da população $\mu$, baseada nas caracteristicas da curva normal.

Considerando que $n$ e $\sigma$ sejam conhecidos, as chances são de 
68,27 em 100 que a média da amostra $\bar{x}$, seja encontrada dentro do intervalo $\pm 1, \frac{\sigma}{\sqrt{N}}$ de $\mu$. Do mesmo modo, a probabilidade é de 95,45 em 100 que $\bar{x}$ seja encontrado dentro de $22 \frac{\sigma}{\sqrt{N}}$ de $\mu$. Este intervalo então, pode ser designado como cobrindo qualquer proba bilidade considerada como $\pm \xi \frac{\sigma}{\sqrt{\mathrm{N}}}$.

Desta forma, $\mu$ irä cair dentro do intervalo $\left(\bar{x}-\xi_{3} \frac{\sigma}{\sqrt{N}}\right) \quad$ a $\left(\bar{x}+\xi \frac{\sigma}{\sqrt{N}}\right)$

Usualmente, ambos cs parâmetros da população $\mu$ e o são des conhecidos mas, as caracteristicas amostrais $\bar{x}$ es são determina das. Nestas condições $\mu$ irä caix dentro do intervalo $\left(\bar{x}-\frac{t s}{\sqrt{N}}\right)$ a $\left(\tilde{x}+\frac{t s}{\sqrt{N}}\right)$. Estes valores säo referidos estatisticamente como limites de confiança.

\section{DIMENS IONAMENTO DE AMOSTRAS}

Sabemos que a determinação das dispersóses deve ser efetuada de modo que $\mathrm{x}$ (mëdia da amostra), seja tão pröxima quanto possî.-. vel de $\mu$ (média do universo) e $s^{2}$ (variância da amostra), seja representativa de $\sigma^{2}$ (variancia do universo). Para tal, $\mathbb{N}$ (ne de observações na amostra) deve ser $N \geq 30$ (universo amostral), para grandes amostras.

Quario substituimos quaisquer dos parametros por sua estima tiva, estaremos cometendo um erro, o erro de amostragem, que tem uma distribuição normal de mẻđia 0 e a variância $\sigma^{2}$.

Por considerações análogas aos efetuados para as distribuições $\xi$ e $t$, temos com $P$ o de certeza que o valor abioluto do erro de arnostragem apresenta a restrição:

$$
|\bar{x}-\mu|<\xi \frac{o}{\sqrt{N}}
$$

Como s ë a estimativa de $\sigma$ baseada em $N \leq 30$ observações, te mos:

$$
\begin{aligned}
& |\vec{x}-\mu|<t \frac{S}{\sqrt{N}} \text { ou } \mu \text { compreendido entre }\left(\bar{x}-t \frac{S}{\sqrt{N}}\right) \\
& \left(\bar{x}+t \frac{S}{\sqrt{N}}\right)
\end{aligned}
$$


Dividindo-se a desigualdade $|\bar{x}-\mu|<\xi \frac{q}{\sqrt{N}}$ por $\mu$, temos:

$$
\left|\frac{\bar{x}-\mu}{\mu}\right|<\frac{\xi}{\sqrt{N}} \frac{\sigma}{\mu}
$$

Chamando-se o 20 membro por exro relativo mäximo, na estima Ção da média $\left(E_{Y}\right)$ e substitujndo $\sigma / \mu$ por $C_{V}$ (coeficiente de va riaçăo), temos :

$$
\mathrm{E}_{\mathrm{I}}=\frac{\xi}{\sqrt{\mathrm{V}}} \mathrm{C}_{\mathrm{V}} \text { ou } \mathrm{N}=\frac{\left(\xi \mathrm{C}_{\mathrm{V}}\right)^{2}}{\mathrm{E}_{\mathrm{X}}}
$$

Analoyamente, quando $N<30$, temos:

$$
N=\frac{\left(t C_{V}\right)^{2}}{E_{x}}
$$

onde:

$$
\mathrm{N}=\mathrm{n} \text { \% minimo de ensaios }
$$

$t$ ou $\xi=$ valores tabelados. Geralmente estes roeficientes são escolhidos para $95 \%$ de probabilidade que os resultados não apresentem um eiro relativo $E_{r}$ da mëila lem nossos estudos admitimos 10\%).

$C_{V}=$ Coeficiente de variação, obtido a partir de rochas mais heterogêneas: Assim, qualquer outra rocha ensaiada de verä cair dentro da dispersão obtja.

Estas expressões permitem determinar o no de elementos que devem compor uma amostra (no de ensaios) para que as estimativas obtiaas a partir da mesma possuam luma precisão pré-fixada

Para a determinação do coeficiente de variação, das formu las acima é necessärio eliminarmos a dispersão devido to erro sistemätico, isto è, a äispersão parcial devido ao equipamento. o procedimento varia conforme a natureza do ensaio:

\section{I. - ENSAIOS NÃO DESTRUTIYOS}

1. Executa-se $N$ ensaios em $N$ corpos de prova da rocha. $O b-$ 
tem-se a dispersão total (devido ao equipamento e heterogeneidade dos corpos de prova rochosos).

2. Para discriminar a dispersão parcial devido ao equipamen to, observa-se 2 procedimentos diferentes que dependem da possibilidade ou não, de modificar as caracteristicas super ficiais de amostras, quando as solicjtações de ensaio são repetidas en um ponto:

2.1- Executamse $N$ ensaios em um ponto de um corpo de prova da rocha. Wão hà modificação das caractexísticas superficlaj.s. Ex. ensaios para determinaçäo da velocidade de propagação de ondas e do módulo dinämico em rochas. obtem-se a dispersão parcial devido ao equipamento, que tambëm pode ser obtida atravês da execuçäo dé iv ensaios em um ou mais pontos de modelos isotropicos. Consideremos materiais teoricamente isotropicos para efeitos de ensaios: vidro, gesso, coramica, calda de cinenco, etc.

2.2 - Executanse ersaios em $N$ pontos do corpo de prova da rocha: Obtem-se a dispersão total.

2.3 - Para ensaios não destrutivos onde ocorre alteraça das caracteristicas superfictais, executa-se frineiramen te ensaios em $N$ pontos do corpo de prova da rocha. Obtemse a dispersão total. Ex: caso de ensaios de dureza dina mica.

2.4 - Executa-se ensaios em $\mathrm{N}$ pontos de modelos isotröp. cos. Obtem-se a dispersão parcial devido ao equipamento.

\section{II. - ENSAIOS DESTRUTIVOS}

1. Executa-se ensaios em $\mathrm{N}$ corpos de prova de modelos iso:tröpicos. Obtem-se a dispersão parcial devido ao equipamento.

2. Executa-se ensaios em $N$ corpos de prova de rocha. Obtemse a dispersão total.

De acordo com Himsworth, visto anteriormente, a variancia total è a soma das variancias causadas por fontes de variação - 
atuando independemtemente. Nestas condições:

$$
s^{2}=s_{0}^{2}+s^{2} \quad \text { ou } \quad s=\sqrt{S 0^{2}+s^{2}}
$$

onde:

$\mathrm{s}^{2}=$ variancia total

$s_{0}^{2}=$ variancia devido ao equipamento

$\mathrm{s}^{2}=$ variância devido a amostra (ou amostras) da rocha

Obtido o valor da variäncia ou desvio padrão da amostra, po demos calculax a dispersão pexcentual dos resultados dos ensaios atravës do coeficiente de variaç $\tilde{c}$,

$$
C_{V}=\frac{S^{\prime}}{\bar{x}} \cdot 100
$$

Para que o no mintirno de ensaios especificado pelo mëtodo de ensaio seja extensivel para todos os materiais rochosos; escolne se a naiox dispersão obtjda nos ensijos preliminares (garalmente em rochas majs anisotroppicas), fara o cälculo do coeficiente de variaço.

\section{CORREIACR̃O E REGRESST̃O}

- método de correlação estatística entre propriedades físicas de rochas a partir de un conjunto do pontos de um diagrama de dispersão, permite a obtengão de uma reta ou curva de correla ção, definida por uma equação de interāependência matemātj.ca,que p ode ser uma função do tipc lineax, exponencial, potencial, etc. Se os dados se aproximarem a uma linha reta, diz-se que exite uma relação linear entre as variáveis. Se a linha curva for a melhor aproximação, diz-se que existe uma relaçãc não linear.

para evitar a subjetividade na construção de linhas, parábo las ou nutres curvas aproximadas ajustarlas a um conjunto de da dos, aplica-se a anälise de regressão pelos minimos quadrados. Neste método, a reta ou curva melhor ajustada é aquela que se ajusta à nuvem de pontos do diagrama de dispersão, quando a soma 
dos quadracios dos desvios dos pontos em relação a esta linha é minima. quando estes desvios sä̀ deteminados ao longo do eixo y, dizemos que $x$ è varjável independente e $y$ a variàvel dependente. Se $x$ e dependente, a situação ë modificada considerando-se os desvios horizontais no lugar dos desvios verticais, o que le va a um intercồnbio dos eixos $x \in y$.

Estas 2 situaçöes, em gexal, levam a diferentes linhas de minimos quacrados. Então, quando estas 2 linhas se aproximarem até coincidirem, constitui urna indicação que os resultados são muto bem descritos por uma relação linear.

o grau de relação entre variäveis, ou correlação, procura .. determinax o quanto uma equaçăo linear ou outra descreve a relam ६ão. Se todos os valores das variáveis satisfazem uma equação exatamente, diz-se que as variáveis estão perfeitamente corcelacionadas, ou que existe uina correlação perfeita entre elas.

Assim, com base nos resultados da amostra, podemos estimar - valor de uma variävej y, correspordendo a um dado valor da va riāvel $x$, a partir de uma linha (ou curva) de minimos quadxados, que se ajusta aos resultados da amostra. A linha resultante $\vec{e}$ chanaâa de linha de regressäo de $\dot{y}$ ern $x$, pois $y$ e estimado a par tir de $X$. Inversamente, o valor de $x$ pode ser estimado a partir da linha de regressão de $x \in y$, no caso en que $x$ e a variävel de pendente e $Y$ a variävel. independente. Em gexal, a linha de regres são ou curva de $Y$ em $X$ não é a mesma da linha ou curva de regres. são de $X$ em $Y$.

A Iinha de regressão dos mínimos quadrados de $\mathrm{Y}$ em $\mathrm{X}$ tem $\mathrm{a}$ equação:

$$
Y=a x+b \text { (para uma relação linear) }
$$

onde:

$\mathrm{X}=$ variävel independente

$Y=$ variavel dependente

$a=$ inclinação da linhà de regressão

$\mathrm{b}=$ interseç̃̃o de $Y$ na linha de regressão.

A intensidade da associação ou relação entre variàveis é definida pelo coeficiente de correlação r, que ë ado pela ex- 
pressão geral:

$$
r=-\sqrt{\frac{\sum(Y \operatorname{est}-\ddot{Y})^{2}}{\sum(Y-\hat{Y})^{2}}}
$$

onde: Yest $=$ valor de $Y$ para dados valores de $X$ estimados a partir de uma relação linear ou não linear.

Esta expressão geral pode sex empregada tanto para as rela cöes lineares como para as não lineares, com uma ünjca diferença do Yest ser calculado por melo de uma equação não linear e dos sinais I serem omitidos. Assim, o valor de r calculado em qual quex caso, fornece o grau de relação correspondente ao tipo de equação que é realmente admitido, isto ê, o coeficiente de corre lação mede a existência do ajustamento aos dados da equação real mente considerada.

Para o caso da correlação linear, I conserva-se o mesmo, quer se considere $X$ ou $Y$ como a variäveI independente. Por isso, - coeficiente de correlação constitui uma boa medida da correlação linear entre 2 variäveis. A expressão geral ficaria então:

$$
r=\frac{x y}{\sqrt{2(x)^{2} \leq(y)^{2}}}
$$

(proporciona automaticamente $0 \mathrm{si}-$ nal adequado de $r$ ).

onde:

$$
\begin{aligned}
& x=x-\bar{x} \\
& y=y-\bar{y}
\end{aligned}
$$

A quantidade $r$ varia entre +1 e - I, que são os valores pa ra uma correlação perfeita. Os sinais + 1 e- -1 , representam res pectivamente uma correlação linear positiva e negativa, isto ë, quardo $r=+i$, as variäveis aumentam ou diminuem concomitante mente e $r=-1$, os grandes vajores de una variävel se associam a pequenos valores da outra. Quando $r=0$, as variäveis não são 
correlacionáveis linearmente (pode haver uma forte correlação não linear).

Entretanto, na prätica, nenhuma correlação ë perfeita. Ao calcularmos o valor de uma variävel, conhecido o valor de outra variável, através da equaçäo de regressão, haverä uma certa va riação en torno do resultado previsto, ou seja, os valores reajs não irão coincidir com os valores teöricos estimados a partir da linhä de regress ão.

A dispersão ao redor da limha de regressão de y em $x$ e deti nida pelo exro padrão da estimativa syx, que è aada pela equaço gera]:

$$
\text { Syx }=\sqrt{\frac{2(Y-\gamma \cot )^{2}}{N-2}}
$$

Esta dispexsão estabelece uma faixa dentro da qual uma de terminada porcentagem de valores irá cair. Do mesno modo, o erro padrão da estimativa de $\mathrm{X}$ em $\mathrm{Y}$ é obtido trocandomse $x$ com $\mathrm{X}$ nesta equação.

o erro padrão da estimativa tem propriedades anälogas aos do desvio padrão. Se as linhas são construlas paralelamente à Iinha de resressäo de $Y$ em $X$ para as distancias verticais respec tivas de \pm Syx, \pm 2 syx $e \pm 3$ syx a partir deIa, aproximadamente $68 \%, 95 \%$ e $99,7 \%$ dos pontos de amostras deverão ser incluidas entre estas linhas.

Analogamente, as consideraçöes estatisticas descritas no item sobre intervalo de confiança são vălidas para se estubele cer a faiza de confiança ao se estimar uma variável conhecenoo se a outra. Neste caso, o desvio padrão é subatituido pelo syx e como o no de pontos de correlaçäo é geralmente $\mathrm{N}<30$, utilizamos o coeficiente $t$ de student para 95\% de confiança, em função do no de graus de liberdade de syx, que no caso ca regressão linear é igual a Nm2 (interdependência entre 2 variäveis). o intervalo de confiar ça (IC) permite então, calcular entre que limites estará $\vec{y}$ para um dado $x_{i}$. A expressão deste intervalo será: 


$$
J C(Y)=Y i \text { calc.tisyx } \sqrt{1+\frac{1}{N}+\frac{(X i-\bar{X})^{2}}{S x x}}
$$

onde:

$S x x=\Sigma_{1}\left(x_{i}-\bar{x}\right)^{2}$

$x_{i}$ calc $=$ obtido da equaçăo para um dado $x$

A análise da expressão dos limites de intervalo de confianca,permite estabelecex aiversas conclusões de inceresse prätico ( 29 ). Assim, a precisão da estimativa de $\bar{y}$ em relação. a $x_{j}$, serä tarto maior quanto:

1. Menor for syx, isto $\ddot{e}$; quanto mais reduzicla for a disper são dos valores observados na amostra sobre a regressão.

2. Maior for $\mathrm{N}$

3. Naior for $S x x$, isto é, a dispexsão dos valores observa dos de $x$ sobre sua mêdia

4. Como a variação de xi. conduz a um alaxgamento do interva lo de confiança, para aumentarmos a precisão da estimati va, devemos observar valores de $x$ afastados da mëdia $\bar{x}$.

5. As estimativas de $\bar{y}$ para valores de $x_{i}$ muto afastados de $x$ apresentam baixa precisão, pois o erro na estimação sera muito grande. 